\title{
Basement membrane antigens in preneoplastic and neoplastic conditions
}

Citation for published version (APA):

Visser, R. (1993). Basement membrane antigens in preneoplastic and neoplastic conditions. [Doctoral Thesis, Maastricht University]. Datawyse / Universitaire Pers Maastricht.

https://doi.org/10.26481/dis.19930513rv

Document status and date:

Published: 01/01/1993

DOI:

10.26481/dis.19930513rv

Document Version:

Publisher's PDF, also known as Version of record

\section{Please check the document version of this publication:}

- A submitted manuscript is the version of the article upon submission and before peer-review. There can be important differences between the submitted version and the official published version of record.

People interested in the research are advised to contact the author for the final version of the publication, or visit the DOI to the publisher's website.

- The final author version and the galley proof are versions of the publication after peer review.

- The final published version features the final layout of the paper including the volume, issue and page numbers.

Link to publication

\footnotetext{
General rights rights.

- You may freely distribute the URL identifying the publication in the public portal. please follow below link for the End User Agreement:

www.umlib.nl/taverne-license

Take down policy

If you believe that this document breaches copyright please contact us at:

repository@maastrichtuniversity.nl

providing details and we will investigate your claim.
}

Copyright and moral rights for the publications made accessible in the public portal are retained by the authors and/or other copyright owners and it is a condition of accessing publications that users recognise and abide by the legal requirements associated with these

- Users may download and print one copy of any publication from the public portal for the purpose of private study or research.

- You may not further distribute the material or use it for any profit-making activity or commercial gain

If the publication is distributed under the terms of Article $25 \mathrm{fa}$ of the Dutch Copyright Act, indicated by the "Taverne" license above, 
BASEMENT MEMBRANE ANTIGENS IN

PRENEOPLASTIC AND NEOPLASTIC CONDITIONS 


\section{CIP GEGEVENS KONINKLIJKE BIBLIOTHEEK, DEN HAAG}

Visser, Robbert

Basement membrane antigens in preneoplastic and neoplastic conditions / Robbert Visser. - Maastricht : Universitaire

Pers Maastricht. - III.

Proefschrift Maastricht. - Met lit. opg. - Met

samenvalting in het Nederlands

ISBN 90-5278-074-9

Tretw.: basaal membraan / immuun histochemie / borderline tumoren.

Produktie: Datawyse | Universitaire Pers Maastricht

Druk: Krips Repro Meppel

This project was financially supported by the Dutch Cancer Society "Het Koningin WIIhelmina Fonds", grant RUL 85-2.

Financial support for the publication of this thesis was given by:

- De Nederlandse Kankerbestrijding - Koningin Wilhelmina Fonds (Dutch Cancer Society)

- De Stichting Bevordering Klinische Pathologie Limburg

- Bank F van Lanschot 


\title{
Basement membrane antigens in preneoplastic and neoplastic conditions
}

\author{
PROEFSCHRIFT \\ ter verkrijging van de graad van doctor \\ aan de Rijksuniversiteit Limburg te Maastricht, \\ op gezag van de Rector Magnificus, Prof.Mr. M.J. Cohen \\ volgens het besluit van het College van Dekanen, \\ in het openbaar te verdedigen \\ op donderdag, 13 mei 1993 om 16.00 uur
}

\author{
door
}

Robbert Visser

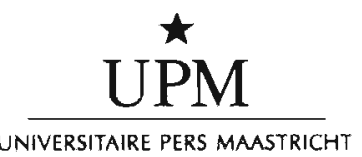


Promotores:

prof.dr. F.T. Bosman

prof.dr. J.W. Arends

Beoordelingscommissie:

prof.dr. F.C.S. Ramaekers, voorzitter

prof.dr. R.W. Stockbrügger

prof.dr. G. Kootstra

prof.dr. J. Drukker

prof.dr. D.J. Ruiter, Katholieke Universiteit Nijmegen

To the memory of my father 


\section{CONTENTS}

\section{CHAPTER 1.}

General Introduction $\ldots \ldots \ldots \ldots \ldots \ldots \ldots \ldots \ldots \ldots \ldots \ldots \ldots$

1.1 Introduction

1.2 The basement membrane composition and architecture

1.2.1 Basement membrane proteins

1.2.1.1 Type IV collagen

1.2.1.2 Laminin

1.2.1.3 Heparan sulphate proteoglycan

1.2.1.4 Additional components

1.2.2 Ultrastructure

1.2.3 Basement membrane heterogeneity

1.3 Tumor invasion and the extracellular matrix

1.3.1 Morphological appearance of the basement membrane in invasion

1.3.2 Biochemical interactions

1.3.2.1 Attachment

1.3.2.2 Modification of the extracellular matrix

1.3.2.3 Locomotion

1.4 Patterns of basement membrane staining in benign and malignant tumors and in tumors of borderline malignancy

1.5 Aim of the study

1.6 References

\section{ChAPTER 2.}

Immunocytochemical detection of basement membrane antigens in the histopathological evaluation of laryngeal dysplasia and neoplasia.

$\begin{array}{ll}2.1 & \text { Introduction } \\ 2.2 & \text { Materials and Methods } \\ 2.2 .1 & \text { Case material } \\ 2.2 .2 & \text { Immunohistochemistry } \\ 2.3 & \text { Results } \\ 2.4 & \text { Discussion } \\ 2.5 & \text { References }\end{array}$

\section{Chapter 3.}

Basement membrane patterns in borderline tumors of the ovary

3.1 Introduction

3.2 Materials and Methods

3.2.1 Immunohistochemistry

3.3 Results

3.3.1 Cystadenoma

3.3.2 Cystadenocarcinoma

3.3.3 Tumors of borderline malignancy 
ChAPTER 4.

Basement membrane immunohistochemistry in renal cell adenocarcinoma

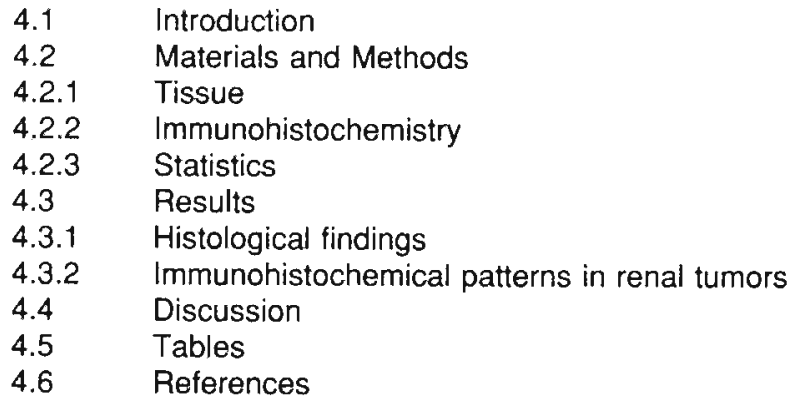

\section{ChAPTER 5.}

Pattern and composition of basement membranes in squamous cell carcinomas of the upper aerodigestive tract

$\begin{array}{ll}\text { 5.1 } & \text { Introduction } \\ 5.2 & \text { Materials and Methods } \\ 5.2 .1 & \text { Tissue } \\ 5.2 .2 & \text { Immunohistochemistry } \\ 5.3 & \text { Results } \\ 5.4 & \text { Discussion } \\ 5.5 & \text { Tables } \\ 5.6 & \text { References }\end{array}$

Chapter 6.

Patterns and composition of basement membranes in colon adenomas and
6.1 Introduction
6.2 Materials and Methods
6.2.1 Tissue
6.2.2 Antibodies
6.2.3 Immunohistochemistry
6.3 Results
6.3.1 Normal mucosa
6.3.2 Adenomas
6.3.3 Adenocarcinomas
6.4 Discussion
6.5 References 
Chapter 7.

Type VII collagen expression in the normal, hyperplastic and neoplastic

endometrium

7.1 Introduction

7.2 Materials and Methods

7.2.1 Endometrial mucosa

7.2.2 Hyperplasia and adenocarcinoma

7.2.3 Antibodies

7.2.4 Immunohistochemistry

7.3 Results

7.3.1 Normal mucosa

7.3.2 Hyperplasia

7.3.3 Adenocarcinoma

7.4 Discussion

7.5 References

ChAPTER 8.

General discussion ..................................... 91

8.1 Basement membrane patterns in benign and in malignant neoplasms

8.2 Potential significance of basement membrane antigens in tumors of borderline malignancy

8.3 Observed basement membrane patterns in tumors of borderline malignancy

8.4 Future perspective

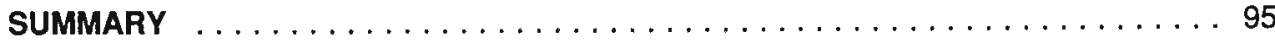

SAMENVATTING $\ldots \ldots \ldots \ldots \ldots \ldots \ldots \ldots \ldots \ldots$

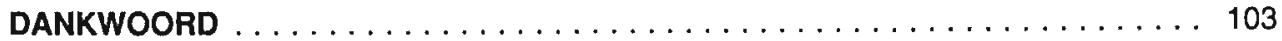

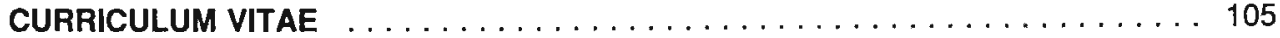





\section{CHAPTER 1}

\section{GENERAL INTRODUCTION*}

\section{$1.1 \quad$ INTRODUCTION}

"Simple, homogeneous, and perfectly transparent membranes, in which no structure can be discovered" were described for the first time by Bowman in 1842 in an article entitled " The structure and use of the Malpighian bodies of the kidney, with observations on the circulation through that gland" (1).

Since the original description of Bowman, the term basement membrane has become widely accepted in the literature, although alternatives such as basal lamina, basement lamina and boundary membrane have been proposed (2).

Although originally described in the uriniferous tube of the kidney, basement membranes are present ubiquitously in most multicellular organisms. In linings of epithelial and endothelial cells basement membranes are found at the basal side of the cell, facing the stroma. In addition they envelope cells in mesenchymal tissues: individual fat cells and contractile cells of heart, smooth muscle and skeletal muscle and also Schwann cells are surrounded by a basement membrane. In contrast, mesenchymal cells such as fibroblasts, histiocytes and blood cells are not surrounded by a basement membrane, and also the endothelium of lymph vessels and the sinusoids of the spleen, lymph nodes and liver lack a continuous basement membrane. The hepatocyte is in fact the only epithelial cell in direct contact with the plasma (3). Myofibroblasts, which play an important role in the maintenance of the extracellular matrix (ECM) do not have a normal, intact basement membrane, but are surrounded by patches of basement membrane material containing type IV collagen, laminin and heparan sulphate proteoglycan $(4,5)$.

In the past, histochemical procedures have been developed to visualize the basement membrane, including the periodic acid Schiff method, which stains carbohydrates (6), as well as silver staining procedures (7). Although the basement membrane zone is visualized in this way, these histochemical reactions are not specific for basement membrane related components, but stain other structures of the extracellular matrix and stroma, such as collagen type I and type III, as well. Immunohistochemical methods with antibodies directed

partially based on: Bosman FT, Havenith MG, Visser R, Cleutjens JPM.

Basement membranes in neoplasia.

Progress in Histochemistry and Cytochemistry 1992; Volume 24 No 2: 1-93 
against basement membrane specific components have overcome this disadvantage and provided a powerful and specific tool for fundamental and diagnostic investigations, which led to unravelling of the basement membrane structure and composition and the establishment of basement membrane staining patterns in normal and pathological conditions.

The basement membrane is a specialized compartment of the extracellular matrix (ECM), which contains at least four classes of macromolecules: the family of collagen proteins; structural glycoproteins such as laminin, fibronectin and entactin; elastin; and proteoglycans. The ECM forms a dynamic environment with major functions in cell differentiation, tissue architecture and function, repair mechanisms, and in pathological conditions like atherosclerosis, diabetes and malignant disease $(3,8,9)$.

The basement membrane is a complex structure, with two distinct layers when visualized electronmicroscopically, by staining with uranyl and osmium combinations. Adjacent to the underlying stroma, a layer with high electron density, the "lamina densa", occurs. A second layer of low electron density occurs adjacent to the cell membrane and is designated "lamina lucida" or "lamina rara". A third layer has been described recently: this part of the basement membrane contains perpendicular fibrils, which contain type VII collagen as a major component. As this part of the basement membrane is in fact not a continuous layer, the term "pars fibroreticularis" is preferred (2). It is suggested that they anchor the basement membrane to the underlying connective tissue.

\subsection{THE BASEMENT MEMBRANE COMPOSITION AND ARCHITECTURE}

Until recently the ECM was regarded as a static framework, supporting and accommodating epithelial and mesenchymal cells. During the past decade much knowledge concerning its structure and function has become available (for recent reviews see 10-13).

Basement membranes are complex and dynamic molecular structures, with a molecular arrangement differing in various organs, according to locally required functions. Components of the basement membrane are synthesized and deposited by cells of both epithelial and mesenchymal derivation $(14,15,16)$. Some aspects of the composition and architecture will be more extensively discussed in the following sections.

\subsubsection{Basement membrane proteins}

ECM components are in general divided into three categories:

(a) collagens, which are the major structural elements;

(b) proteoglycans, highly charged molecules regulating fibre size, hydration and tissue permeability, and

(c) glycoproteins which link matrix components and cells.

The collagens of the extracellular matrix form a heterogeneous family of proteins, which are chemically and immunologically distinct.

The basement membrane, as a specialized compartment of the extracellular matrix, contains a variety of other specific proteins. Martinez-Hernandez and Amenta (3) proposed a distinction between "intrinsic" components, i.e. type IV collagen, laminin and heparan sulphate proteoglycan, proteins which occur (almost) exclusively in basement membranes, and "extrinsic" components, which are present in basement membranes with specialized functions, but can also be found in other (extracellular matrix) structures.

\subsubsection{Type IV collagen}

Type IV collagen is the most important structural component of the basement membrane. The formation of a stable network, serving as a supportive structure, is the major function of this protein. Other functions include binding sites for other components like laminin, proteoglycan and nidogen. 
The type IV collagen triple helix molecule is composed of four distinct polypeptide chains. Originally two $\alpha$ chains were identified: $\alpha 1$ (IV) and $\alpha 2$ (IV), which are arranged in a $390 \mathrm{~nm}$ long triple helical rod, with a globular domain ("NC1-domain") at the carboxy-terminus and a $30 \mathrm{~nm}$ long segment at the amino-terminus of the triple helix ("7S domain") (17). Recently two additional type IV collagen polypeptide chains have been described, i.e. $\alpha 3(\mathrm{IV})$ and $\alpha 4$ (IV) $(18,19)$.

These domains are the sites of the molecule where oligomers are generated by interaction between the NC1 domains, leading to dimers, and of lateral association of the 75 domains and resulting in tetramers $(17,20,21)$.

\subsubsection{Laminin}

Laminin is a noncollagenous glycoprotein with a molecular weight of $900 \mathrm{kD}$. It forms complexes with other basement membrane components such as type IV collagen (22-24) and nidogen/entactin (25). It possesses distinct cell-binding properties and influences cell differentiation and movement (26-31). The molecule has a cross-shaped structure with three similar short arms and one long arm terminated by globular domains (32-34). The protein consists of three polypeptide chains: two chains with a molecular mass of about $200 \mathrm{kD}$ (B1 and B2 chains) and a large chain of about $400 \mathrm{kD}$ (A chain). These chains are attached to each other by disulphide bonds.

\subsubsection{Heparan sulphate proteoglycan}

Basement membranes contain at least three different proteoglycans, with heparan sulphate proteoglycan (35) as the most important, and two smaller high density proteoglycans, with either heparan sulphate or chondroitin sulphate side chains (36).

Heparan sulphate proteoglycan was found in in the lamina lucida, where it forms clustered aggrgates and in the lamina densa.

It has been suggested, that proteoglycans have affinity for laminin and for the NC1 domain of type IV collagen and may be involved in the attachment of cells to basement membranes and in the maintenance and remodelling of basement membranes (8).

\subsubsection{Additional components}

Fibronectin is a widespread glycoprotein, and occurs in the extracellular matrix as well as in fibrous tissues and in plasma. It is capable of multiple interactions with cell surfaces and other matrix components (37). Fibronectin may promote extracellular matrix assembly and cell adhesion to these matrices. Together with laminin, fibronectin plays a major role in tumor invasion.

Type VII collagen is the largest member of the collagen family. It consists of three identical $\alpha$-chains with a $150 \mathrm{kD}$ globular domain at the carboxyl-terminus that is attached to a helical section of $170 \mathrm{kD}(38)$.

The protein, that is secreted by keratinocytes (39), is now thought to be the major structural component of the anchoring fibrils which link the basement membrane to the underlying stroma. Monoclonal antibodies have been raised against type VII collagen $(40,41)$. These antibodies bind exclusively to the dermal/epidermal junction, to the basement membrane of epithelia in tissues such as the breast, prostate, amnion and bronchus and stratified epithelia of the larynx, esophagus, trachea, vagina and ectocervix (40-43). In the epithelial basement membrane of the major part of the gastrointestinal tract (liver, stomach and intestine) and in the basement membrane of bloodvessels, muscle and nerve fibers type VII collagen was not observed (43).

Nidogen, a sulphated glycoprotein, was described in 1983 by Timpl et al (44). It consists of a single polypeptide chain with a molecular weight of approximately $150 \mathrm{kD}$ and is 
distributed ubiquitously, similar to the distribution of laminin and type IV collagen. It has been suggested that nidogen mediates the binding of laminin to type IV collagen (8).

By immunoelectronmicroscopy it was shown that the basement membranes may differ in their content and distribution of laminin and nidogen (45).

A recently described extraceilular matrix glycoprotein is tenascin, a $150-240 \mathrm{kD}$ molecule, which appears to play a major role in tissue development. It is distributed in the mesenchyme surrounding developing epithelia during embryogenesis of various organs (46). Tenascin was also found in neoplasms, where the molecule is expressed throughout the stroma, with increasing intensity in relation to an increasing degree of atypia and malignancy $(47,48,49)$.

\subsubsection{Ultrastructure}

Examination of the basement membrane by light microscopy shows a thin, continuous and apparently homogeneous structure, after routine staining for example by the periodic acidSchiff reaction. Ultrastructurally the typical basement membrane appears to be composed of three distinct layers (50-53). The lamina densa, which is the most prominent layer, is composed of a network of anastomosing linear fibrils which show a diameter ranging from 1.8-5.3 nm (53-55).

The lamina lucida, situated between the cell membrane and the lamina densa, is electron lucent and is crossed by fine fibrils from the lamina densa which are in continuity with the adjacent cell. Extensions of the lamina densa are found in the pars fibroreticularis, together with anchoring fibrils and microfibrils. These structures secure an intimate connection between the basement membrane and connective tissue. Anchoring fibrils, which are found along the interface between the basement membrane in some epithelia and the adjacent stroma, connect the lamina densa with anchoring plaques, which are electron-dense islands in the stroma. Type VII collagen is a major structural component of these anchoring fibrils.

At sites where fusion of two basement membranes has occurred, as in the renal glomerulus, a lamina lucida is present on both sides of the lamina densa.

\subsubsection{Basement membrane heterogeneity}

In view of the diverse functions of the cell types, that are surrounded by a basement membrane, and the contribution of this structure to many of these specialized functions (56), it is conceivable, that the biochemical composition of the basement membrane differs from organ to organ and that disease might influence this composition as well. Ultrastructural and immunohistochemical studies using monoclonal antibodies has indeed shown considerable heterogeneity and organ specificity during embryonal development, between different anatomical sites, and according to physiological functions (3, 57-59). In several pathological conditions including diabetes and glomerular disease, morphological and biochemical changes have been described. In neoplasia, basement membranes are found that are morphologically and biochemically indistinguishable from the tissues of origin; however, in invasive tumors, a variety of structural alterations have been described $(60,61)$

\subsection{TUMOR INVASION AND THE EXTRACELLULAR MATRIX}

When fumor cells acquire the capacity of invasive growth, a complex sequence of events is involved. Although features morphologically characteristic for invasion may not be observed at an early stage, the expression of a variety of proteases, involved in degradation of the extracellular matrix, may be encountered (table 1). 
TABLE 1 -Tumor cell proteases associated with invasion (62)

\begin{tabular}{|l|l|l|}
\hline & PROTEASE & SUBSTRATE \\
\hline 1 & interstitial collagenase & collagens type I, II and III \\
\hline 2 & $\begin{array}{l}\text { basement membrane collage- } \\
\text { nase }\end{array}$ & type IV collagen \\
\hline 3 & plasminogen activator & $\begin{array}{l}\text { plasminogen to plasmin; plasmin degrades non-collagenous } \\
\text { matrix }\end{array}$ \\
\hline 4 & cathepsin B, cysteine protease & glycoproteins, activates proenzymes, procollagen peptides \\
\hline 5 & heparanase & proteoglycans \\
\hline 6 & hyaluronidase & hyaluronic acid \\
\hline
\end{tabular}

In addition, it was recently found, that cell-surface molecules, collectively known as cell adhesion molecules (CAM's) also play a role in behaviour of neoplastic cells. The group of CAM's, that normally regulate physiological processes such as growth, differentiation and organization of cells in tissues by cell to cell and cell to matrix interactions, contains four families of molecules, which differ in molecular structure (63).

Future research in this field of cell-surface molecules and matrix degrading molecules might result in the development of sensitive parameters for the immunohistochemical determination of the earliest stages of invasive growth. Although this field is rapidly developing, it will not be discussed further here.

\subsubsection{Morphological appearance of the basement membrane in invasion}

In carcinoma in situ, ultrastructural studies have disclosed focal defects in the continuity of the basement membrane. These defects may reflect the earliest stages of progression to invasive carcinoma that can be visualized presently $(64,65)$. In non-invasive benign tumors the basement membrane is nearly always intact. In frankly invasive lesions, however, abnormal patterns, including absence of or discontinuities in the basement membrane are invariably encountered.

\subsubsection{Biochemical interactions}

In tumor invasion, the initial event is degradation of the basement membrane, followed by active migration of the tumor cells through the basement membrane into the adjacent tissue. In an attempt to explain this sequence of events, Liotta et al (13) proposed a threestep hypothesis for tumor invasion. In this concept the first step is tumor cell attachment to the basement membrane via cell surface receptors that specifically bind to components of the basement membrane. The second step is proteolysis, modification of extracellular matrix components by proteolytic enzymes secreted by tumorcells, or by host cells under the influence of tumor cells. The third step is tumor cell locomotion, which is directed by the modified matrix.

\subsubsection{Attachment}

Recent data suggest that in the process of tumor cell invasion and metastasis complex interactions between tumor cells and extracellular matrix play an important role. These interactions are mediated by a group of cell surface receptors, which under physiological conditions influence many processes such as cellular growth and differentiation, intercellular junction formation and cell polarity and are involved in wound healing, the 
inflammatory response and also in the host reaction to neoplasia (66-72). Four families of cell surface molecules or cell adhesion molecules (CAM's) have been identified:

1- The group of integrins. This family of about 10 different types of adhesion molecules is composed of two subfamilies (alpha and beta), which form heterodimers.

2- A large family of molecules that structurally resemble immunoglobulins. Only a few molecules of this family are CAM's.

3- A group of calcium dependent membrane glycoproteins called Cadherins, and

4- A more recently identified family of lectin-like glycoproteins.

During the past years much research has been devoted to the structure and function of integrins and these efforts have made them among the best understood in the family of cell adhesion molecules $(66,67)$.

Because of their mediating role in cell-extracellular matrix interactions as well as cell-cell adhesion, it is likely that integrins are involved in each of the three steps of invasion: attachment of the tumor cell (by integrin receptors for the basement membrane components laminin and type IV collagen), proteolytic degradation of the basement membrane (through modulation of the expression of proteolytic enzymes) and, finally, migration into the underlying stroma through adhesion to interstitial collagens (type I and III).

\subsubsection{Modification of the extracellular matrix}

Following attachment, the tumor cell secretes enzymes which can locally degrade the extracellular matrix. In addition, the tumor cell may be capable to stimulate host cells to produce proteolytic enzymes. The release of these proteolytic enzymes may be mediated by cell-extracellular matrix interactions: binding extracellular matrix ligands to their integrin receptors may result in synthesis and release of proteases, which are involved in basement membrane degradation.

The target substrates are the matriceal components and the result is local degradation of the extracellular matrix with hydratation and expansion of the viscoelastic ground substance. In this way an environment is created, that is conducive for invading tumor cells.

Several proteases, involved in this process have already been identified (table 1).

Local degradation of the basement membrane, through lysis of type IV collagen occurs through specific collagenases and other proteases such as elastase, plasmin and cathepsins.

Non-collagenous macromolecules of the extracellular matrix such as glycoproteins and proteoglycans are degraded by glycosidases, which cleave the glycosaminoglycan sidechains.

The plasminogen activator/plasmin system also plays a role in modification of the extracellular matrix. Two types of plasminogen activator (PA) have been identified in neoplastic tissue: a urokinase-like PA, which is secreted by most carcinomas, and a tissue activator type PA $(62,71)$. The tissue activator type PA plays a major role in thrombolysis; as such it may participate in fibrin degradation at the primary tumor site and contribute to tumor cell release.

In addition, plasmin may be involved in the activation of type IV collagenase (73) and furthermore it can degrade both laminin and fibronectin $(74,75)$.

\subsubsection{Locomotion}

The third step in the process of invasion is tumor cell motility, which follows attachment and local proteolysis of the extracellular matrix. Cell motility is an essential step for tumor cells to reach neighbouring compartments such as the adjacent stroma, vascular walls and distant organs and probably involves chemotactic mechanisms.

It has been suggested, that an autocrine motility factor is secreted by the tumor cell and recognizes a tumor cell surface receptor (76). This results in stimulation of cell movement, 
a major function in this phase of invasion. For active movement of the tumor cells through the enzymaticaily altered extracellular matrix, attachment to extraceliular matrix elements is mediated by receptors, including those of the integrin family.

\subsection{PATIERNS OF BASEMENT MEMBRANE STAINING IN BENIGN AND MALIG- NANT TUMORS AND IN TUMORS OF BORDERLINE MALIGNANCY}

\section{Normal tissue patterns}

In general, the tissues of every organ of the body contain continuous and regular basement membranes, as has already been outlined. The epithelia of the skin, the endocrine system and the respiratory, genitourinary and gastrointestinal tracts are separated from the adjacent stroma by a basement membrane. The central nervous system, in contrast, contains only vascular basement membranes, whereas Schwann cells of the peripheral nervous system are enveloped by basement membranes. Mesenchymal cells such as adipocytes, cardiac, skeletal and smooth muscle cells also are surrounded by a basement membrane. However, fibroblasts, histiocytes, blood cells and, exceptionally, epithelial cells such as hepatocytes lack a basement membrane. Myofibroblasts are surrounded by patches of basement membrane components (5).

\section{Basement membranes in benign tumors}

Although most investigations have focused mainly on basement membrane characteristics in connection with tumor invasion and metastasis, several studies have reported patterns of basement membrane staining in benign tumors, a summary of which is given in Table 2.

In general terms, the results of these studies reconfirm the continuity of basement membranes in benign, reactive proliferations and in benign tumors. However, basement membrane interruptions have been found in benign lesions $(85,102,108)$, but these interruptions were mostly related to an adjacent inflammatory infiltrate. As inflammatory cells are known to secrete collagenase, it can be assumed that these are responsible for the local breakdown of the basement membrane (104).

Some benign tumors may be very difficult to distinguish from malignant tumors because of their morphological similarity. An example, familiar to every diagnostic pathologist, is sclerosing adenosis of the female breast, which can be very difficult to distinguish from tubular carcinoma. Basement membrane immunohistochemistry may facilitate a solution of this diagnostic problem, because in sclerosing adenosis the basement membranes are intact and continuous, but in the tubular carcinoma they are typically interrupted or even completely absent.

In addition, basement membrane immunohistochemistry may assist in discriminating between inflammatory lesions and malignant tumors. An example is chronic pancreatitis, which leads to abundant fibrous tissue, surrounding irregular ducts. This can be difficult to distinguish from pancreatic carcinoma. Also in the pancreas the inflammatory lesion shows intact epithelial basement membranes, whereas in carcinoma these may be interrupted or even absent $(84,105,106)$. 
TABLE 2. Basement membrane patterns in preneoplastic human lesions and benign neoplasms.

\begin{tabular}{|c|c|c|c|}
\hline Organ & Type of neoplasm & Basement membrane morphology & Ret. \\
\hline Skin & $\begin{array}{l}\text { benign adnexal tumors } \\
\text { actinic keratosis } \\
\text { nevocellular nevi } \\
\text { melanoma juvenile }\end{array}$ & $\begin{array}{l}\text { continuous, thickened, multilamellar } \\
\text { continuous } \\
\text { continuous } \\
\text { almost continuous }\end{array}$ & $\begin{array}{l}77 \\
78-81 \\
81 \\
81\end{array}$ \\
\hline Breast & $\begin{array}{l}\text { fibroadenoma } \\
\text { fibrocystic disease } \\
\text { sclerosing adenosis }\end{array}$ & $\begin{array}{l}\text { continuous to thickening and splitting } \\
\text { idem } \\
\text { continuous }\end{array}$ & $\begin{array}{l}82,83 \\
83,84 \\
83\end{array}$ \\
\hline respiratory tract & hyperplasia & continuous & 85 \\
\hline Digestive tract & $\begin{array}{l}\text { pleomorphic adenoma } \\
\text { benign odontogenic tumor } \\
\text { Whartin's tumor } \\
\text { hyperplastic polyps } \\
\text { hamartomas } \\
\text { carcinoids, benign variant } \\
\text { adenomas }\end{array}$ & $\begin{array}{l}\text { variable } \\
\text { continuous } \\
\text { idem } \\
\text { idem } \\
\text { idem } \\
\text { idem } \\
\text { idem }\end{array}$ & $\begin{array}{l}86,87 \\
88,89 \\
87 \\
90 \\
90 \\
90 \\
90\end{array}$ \\
\hline Endocrine system & $\begin{array}{l}\text { thyroid: adenomas } \\
\text { adrenal: pheochromocytoma }\end{array}$ & $\begin{array}{l}\text { continuous } \\
\text { regular and continuous }\end{array}$ & $\begin{array}{l}91-94 \\
10\end{array}$ \\
\hline Genitourinary system & $\begin{array}{l}\text { endometrium: hyperplasia } \\
\text { ovary: cystadenoma } \\
\text { : fibroma } \\
\text { : thecoma }\end{array}$ & $\begin{array}{l}\text { continuous } \\
\text { continuous } \\
\text { absent } \\
\text { scanty }\end{array}$ & $\begin{array}{l}95,96,97 \\
98 \\
98 \\
98\end{array}$ \\
\hline Nervous system & $\begin{array}{l}\text { ependymoma } \\
\text { choroid plexus papilloma } \\
\text { meningeoma } \\
\text { neurilemmoma }\end{array}$ & $\begin{array}{l}\text { continuous } \\
\text { continuous } \\
\text { variable } \\
\text { continuous }\end{array}$ & $\begin{array}{l}99 \\
99 \\
99 \\
100\end{array}$ \\
\hline Soft tissue & $\begin{array}{l}\text { leiomyoma, hemangioma, lipoma } \\
\text { fibrous tissue tumors }\end{array}$ & $\begin{array}{l}\text { abundant } \\
\text { absent }\end{array}$ & $\begin{array}{l}101,102 \\
101,102\end{array}$ \\
\hline
\end{tabular}

\section{Basement membranes in malignant tumors}

One of the major hallmarks of malignant neoplasia is the occurrence of invasive growth. Invasive growth of malignant tumors would conceivably be reflected in irregular or absent basement membranes. The immunohistochemically stained basement membrane patterns in malignancy have been the subject of many investigations during the last decade. The results of these studies are briefly summarized in Table 3.

As could be expected, most of the studied malignant neoplasms showed defective basement membranes. However, the ability of tumors to deposit new basement membranes appeared to vary and as such could be related with the degree of differentiation of the tumor cells. Poorly differentiated tumors may deposit little or no basement membrane material, while highly differentiated carcinomas may show extensive deposition of often regular basement membranes. The correlation between basement membrane deposition and tumor cell differentiation has been described in carcinomas of the stomach, colon, pancreas, endometrium, prostate, uterine cervix and in neuroendocrine carcinoma. Examples of a tumor in which abundant basement membrane material is deposited are malignant melanoma, thyroid carcinoma and adrenal carcinoma. However, the presence of extensive and continuous deposits of basement membrane material in these malignant tumors is not in contradiction with their invasive nature. 
TABLE 3: Basement membrane patterns in malignant neoplasms.

\begin{tabular}{|c|c|c|c|}
\hline Organ & Type of neoplasm & $\begin{array}{l}\text { Basement membrane } \\
\text { morphology }\end{array}$ & Ret. \\
\hline Skin & $\begin{array}{l}\text { squamous cell carcinoma } \\
\text { basal cell epithelioma, } \\
\text { melanoma, lentigo maligna } \\
\text { melanoma, superficial spreading } \\
\text { melanoma, nodular } \\
\text { malignant adnexal tumors } \\
\text { cylindroma }\end{array}$ & $\begin{array}{l}\text { continuous to almost total absence } \\
\text { continuous to irregular } \\
\text { intact } \\
\text { discontinuous } \\
\text { discontinuous } \\
\text { discontinuous to irregular patterns } \\
\text { extensive deposition }\end{array}$ & $\begin{array}{l}107-110 \\
110-113 \\
81,113 \\
81,113 \\
81,113-116 \\
117 \\
116-119\end{array}$ \\
\hline Breast & lobular and ductal carcinoma & discontinuous to absent & $\begin{array}{l}43,61,83 \\
118 \cdot 122\end{array}$ \\
\hline Respiratory tract & $\begin{array}{l}\text { tarynx: invasive carcinoma } \\
\text {-bronchus: squamous cell carcinoma } \\
\text { adenocarcinoma }\end{array}$ & $\begin{array}{l}\text { discontinuous } \\
\text { discontinuous } \\
\text { discontinuous }\end{array}$ & $\begin{array}{l}85,122-125 \\
125-129 \\
129\end{array}$ \\
\hline Digestive tract & $\begin{array}{l}\text {-salivary glands: adenoid cystic carcinoma } \\
\text { mucoepidermoid tumor } \\
\text {-oralloesophagus: } \\
\text { squamous cell carcinoma } \\
\text { odontoma } \\
\text { ameloblastoma } \\
\text {-stomach: adenocarcinoma } \\
\text { neuroendocrine carcinoma } \\
\text {-colon: adenocarcinoma } \\
\text {-pancreas: adenocarcinoma } \\
\text {-hepatobiliary: sclerosing cholangiocarcinoma } \\
\text { hepatocellular carcinoma }\end{array}$ & $\begin{array}{l}\text { extensive, continuous } \\
\text { discontinuous } \\
\text { discontinuous } \\
\text { regular, continuous } \\
\text { focal discontinuities } \\
\text { discontinuous to absence } \\
\text { variable } \\
\text { discontinuous to total absence } \\
\text { continuous to almost absence } \\
\text { continuous to aimost absence } \\
\text { tragmented deposition }\end{array}$ & $\begin{array}{l}116-119 \\
77,87 \\
132 \\
88,89 \\
89 \\
12 \\
12 \\
134-138 \\
84,105 \\
84,106 \\
138,139\end{array}$ \\
\hline Endocrine system & $\begin{array}{l}\text { thyroid: follicular carcinoma } \\
\text { papillary carcinoma } \\
\text { medullary carcinoma }\end{array}$ & $\begin{array}{l}\text { continuous to almost absence } \\
\text { discontinuities } \\
\text { scattered deposits }\end{array}$ & $\begin{array}{l}10 \\
10,94,120 \\
10\end{array}$ \\
\hline $\begin{array}{l}\text { Genitourinary } \\
\text { system }\end{array}$ & $\begin{array}{l}\text {-bladder: grade I papillary carcinoma } \\
\text { grade II and III papillary carcinoma } \\
\text {-prostate: adenocarcinoma } \\
\text {-cervix: squamous carcinoma } \\
\text {-endomelrium: adenocarcinoma } \\
\text {-ovary: carcinosarcoma and mixed Mülierian tumor }\end{array}$ & $\begin{array}{l}\text { continuous to interruptions } \\
\text { discontinuities to absence } \\
\text { almost continuous to absence } \\
\text { almost continuous to absence } \\
\text { almost continuous to absence } \\
\text { discontinuous in opithelial areas and } \\
\text { scattered in non-epithelial areas }\end{array}$ & $\begin{array}{l}140 \cdot 144 \\
43,141 \cdot 144 \\
144,145 \\
146-149 \\
43,149 \cdot 150 \\
98\end{array}$ \\
\hline Nervous system & $\begin{array}{l}\text { glioma-sarcoma } \\
\text { malignant Schwannoma }\end{array}$ & $\begin{array}{l}\text { Scattered } \\
\text { discontinuous to absent }\end{array}$ & $\begin{array}{l}99 \\
99,101,102\end{array}$ \\
\hline Sott tissue & $\begin{array}{l}\text { synoviosarcoma } \\
\text { hemangiosarcoma } \\
\text { malignant hemangiopericytoma } \\
\text { liposarcoma } \\
\text { rhabdo-, leiomyosarcoma }\end{array}$ & $\begin{array}{l}\text { almost continuous around epithelial } \\
\text { compartment } \\
\text { vascular pattern } \\
\text { pericellular pattern } \\
\text { variable } \\
\text { variable }\end{array}$ & $\begin{array}{l}84,101,120 \\
101 \\
101 \\
101 \\
101,151\end{array}$ \\
\hline
\end{tabular}


The propensity of these tumors to synthesize and deposit basement membranes might reflect their biological potential and, as such, may contain prognostic information. Studies concerning this possibility in carcinomas of the lung, colon and bladder have indeed shown a positive correlation between extensive deposition of basement membranes by the tumor and a more favourable course of the disease $(128,134,135,140)$.

Also in soft tissue tumors basement membrane immunohistochemistry may yield important information. Certain sarcomas may be diagnosed more readily, owing to the ability of the tumor cells to deposit basement membrane material. For instance, leiomyosarcomas are composed of cells that are individually enveloped by a basement membrane. Fibrosarcoma cells, however, do not deposit basement membrane material. In this way, basement membrane immunohistochemistry can be a valuable tool in distinguishing these categories of spindle cell tumors.

\section{Basement membranes in tumors of borderline malignancy}

Unlike the situation in benign or malignant tumors, basement membrane immunohistochemistry has not been extensively explored in tumors of borderline malignancy. As summarized in Table 4, studies have been largely restricted to epithelial dysplasia and in situ carcinoma in the uterine cervix and also to adenomas in the colorectum. Series of lesions usually contained borderline tumors with intact basement membranes in addition to tumors with focally interrupted basement membranes.

Table 4: Basement membrane patterns in premalignant lesions and tumors of borderline malignancy.

\begin{tabular}{|l|l|l|l|}
\hline Organ & Type of neoplesm & $\begin{array}{l}\text { Basement membrane } \\
\text { morphology }\end{array}$ & Ret. \\
\hline Skin & $\begin{array}{l}\text { Bowen's disease } \\
\text { actinic keratosis }\end{array}$ & $\begin{array}{l}\text { continuous } \\
\text { continuous }\end{array}$ & $\begin{array}{l}77,78,107 \\
77-80\end{array}$ \\
\hline Breast & $\begin{array}{l}\text { intraduct and intralobular } \\
\text { carcinoma }\end{array}$ & continuous & 82 \\
\hline Respiratory tract & $\begin{array}{l}\text {-larynx: hyperplasia } \\
\text { dysplasia }\end{array}$ & $\begin{array}{l}\text { continuous } \\
\text { continuous }\end{array}$ & $85,79,123$ \\
\hline Digestive tract & -colon: adenoma with dysplasia & focal interruptions & 79,84 \\
\hline Endocrine system & carcinoid, islet cell tumor & continuous & 152,153 \\
\hline $\begin{array}{l}\text { Genitourinary } \\
\text { system }\end{array}$ & $\begin{array}{l}\text {-prostate: severe dysplasia } \\
\text {-endometrium: adenomatous } \\
\text { hyperplasia } \\
\text {-cervix: dysplasia } \\
\text { carcinoma in situ }\end{array}$ & $\begin{array}{l}\text { discontinuous } \\
\text { intact or disruptions }\end{array}$ & 10,152 \\
\hline
\end{tabular}

\subsection{AIM OF THE STUDY}

In the last decade many new facts were unveiled regarding the physiological and biochemical properties of the extracellular matrix including

the basement membrane. The literature reviewed in the previous paragraphs has highlighted current opinions regarding the biochemical aspects of the tumor cellextracellular matrix interaction. Isolation and purification of basement membrane components and the production of

polyclonal and monoclonal antibodies directed against these components, in particular against laminin, type IV collagen and type VII collagen, has allowed visualization of the 
basement membrane in normal and pathological conditions. Especially in the field of neoplastic disease the use of immunohistochemistry with antibodies directed against basement membrane components has resulted in a large number of publications that have expanded our knowledge of the basement membrane structure in normal tissues and in neoplasia, in particular in invading malignant tumors. Relatively few investigations have focused on basement membrane immunohistochemistry in preneoplastic lesions and tumors of borderline malignancy.

Therefore we initiated a series of studies to investigate the characteristics of the basement membrane immunohistochemically in the transition from benign to malignant. In these studies antibodies were used against basement membrane proteins laminin, type IV collagen and type VII collagen.

The following questions were addressed:

1-Are basement membrane patterns in epithelial dysplasia of varying grades of severity, different from those in in situ carcinoma? Can in situ carcinomas be subdivided according to their basement membrane status (continuous or discontinuous)?

2-Do basement membrane patterns in tumors, that are classified as of borderline malignancy, allow a distinction between benign (continuous) and incipiently malignant (discontinuous)?

3-Does type VII collagen play a role in the transition from benign to malignant neoplasia?

In chapter 2 the basement membrane patterns in laryngeal carcinoma in situ, dysplasia and hyperplasia are described using immunohistochemistry and applying antibodies directed against type IV collagen and laminin.

In chapter 3 basement membrane patterns in a series of borderline tumors of the ovary are reported in comparison with patterns in benign cystadenomas of the ovary and cystadenocarcinomas.

Another example of a class of tumor that stands on the borderline between benign and malignant is the renal cortical (tubular) adenoma. Some authors rely mainly on the diameter of the tumor to determine the nature of the neoplasm.

In chapter 4 we report on the results of a study to determine the nature of renal cortical epithelial tumors with a diameter ranging from millimetres to centimetres, with emphasis on patterns of the basement membrane staining using antibodies against type IV collagen and laminin. The aim of this study was to find criteria for benign and malignant renal cell tumors, based on basement membrane characteristics.

In chapter 5 we report on the results of a study regarding the patterns of type IV collagen and type VII collagen staining in squamous cell carcinoma of the upper aerodigestive tract, with emphasis on the relation of these patterns with tumor differentiation.

In chapters 6 and 7 studies are described concerning basement membrane patterns in the normal mucosa of the colon and endometrium and in preneoplastic lesions such as adenomas and hyperplasia. Especially the presence and distribution of type VII collagen was addressed, as this protein has been mainly associated with anchoring fibrils, which do not normally occur in these epithelia.

Finally, in chapter $\mathbf{8}$, the results of these studies are discussed in more general terms. Some remarks are made regarding applicability of basement membrane immunohistochemistry in diagnostic histopathology. 
1. Bowman $W$. On the structure and use of the malpighian bodies of the kidney, with observations on the circulation through that gland. Phil Transactions Royal Soc London 1842; 132: 57-80.

2. Inoue S. Uitrastructure of basement membranes, Int Rev Cytol 1989; 117: 57-99.

3. Martinez-Hernandez A, Amenta PS. The basement membrane in pathology. Lab Invest 1983; 48: 656-677

4. Lipper S, Kahn LB, Reddick RL. The myofibroblast. Pathol Annu 1980; 15: 409- 413.

5. Seemayer TA, Schurch W, Lagace R. Myofibroblasts in human pathology. Hum Pathol 1981; 12; 491-493

6. Lillie RD. Reticulum staining with Schiff reagent after oxidation by acidified sodium periodate. J Lab Clin Med 1947; 32: 910-912.

7. Jones DB. Inflammation and repair of the glomerulus. Am J Pathol 1951; 27: 991- 1009

8. Timpl R. Structure and biological activity of basement membrane proteins. Eur J Biochem 1989; 180: 487502.

9. Weber L. Krieg T. Timpl R. Basal membranen: Struktur, Funktion, Pathologie. Hautarzt 35; 1964: $279-286$.

10. Bosman FT, Havenith MG, Visser R, Cleutjens JPM. Basement membranes in neoplasia. Progr Histochem Cytochem 1992; 24 (4): 1-94

11. Rubin E, Farber JL. (eds). Pathology. 1988. Lippincott Comp, Philadelphia USA; 66.-77.

12. d'Ardenne AJ. Use of basement membrane markers in tumour diagnosis. J Clin Pathol 1989; 42: 449-457.

13. Liotta LA, Rao CN, Barsky SH. Tumor invasion and the extracellular matrix. Lab Invest 1983; 49: 636-650.

14. Weiser MM, Sykes DE, Killen PD. Rat intestinal basement membrane synthesis. Epithelial versus nonepithelial contributions, Lab Invest 1990; 62: 325-330.

15. Cleutjens JPM, Havenith MG, Beek $C$, Vallinga M, ten Kate J, Bosman FT. Origin of basement membrane type IV collagen in xenografted human epithelial tumor cell lines. Am J Pathol 1990; 136: 1165-1172.

16. Damjanov I, Damjanov N, Knowles BB, Engvall E. Origin of laminin in the extracellular matrix of human tumor xenogratts in nude mice. Virchows Arch(B) 1985; 49: 45-52.

17. Timpl R, Oberbäumer I, Furthmayr $H$, Kuehn K. Macromolecular organization of type IV collagen. 1982 In: New trends in basement membrane research. H.Kuehn, H. Schoene and R. Timpl eds. Raven Press, New York, 57-67.

18. Butkowski R, Langeveld JP, Wieslander J, Hamilton J, Hudson BG. Localization of the Goodpasture epitope to a novel chain of basement membrane collagen. J Biol Chem 1987; 262: 7874-7877.

19. Saus J. Wieslander J, Langeveld JP, Quinones S, Hudson BG. Identification of the Goodpasture antigen as the alpha 3(IV) chain of collagen IV. J Biol Chem 1988; 263: 13374-13380.

20. Yurchenco PD and Furthmayr $\mathrm{H}$. Self-assembly of basement membrane collagen. Biochemistry 1984; 23 ; 1839-1850.

21. Laurie GW, Bing JT, Kleinman HK, Hassell JR, Aumailley M, Martin GR, Feldmann RJ. Localization of binding sites for laminin, heparan sulfate proteoglycan and fibronectin on basement membrane (type IV) collagen. J Mol Biol 1986; 189: 205-216.

22. Terranova VP, Rohrbach DH, Martin GR. Role of laminin in the attachment of PAM 212 (epithelial) cells to basement membrane collagen. Cell 1980; 22: 719-726.

23. Rao CN, Margulies IMK, Tralka TS, Terranova VP, Madri JA, Liotta LA. Isolation of a subunit of laminin and its role in molecular structure and tumor cell attach ment. J Biol Chem 1982; 57: 9740-9744.

24. Woodley DT, Rao CN, Hassell JR, Liotta LA, Martin GR, Kleinman HK. Interactions of basement membrane components. Biochim Biophys Acta 1983; 761: 278-283.

25. Carlin BE, Durkin ME, Bender $B$ Jaffe R, Chung AE. Synthesis of laminin and entactin by F9 cells induced with retinoic acid and dibutyryl cyclic AMP. J Biol Chem 1983; 258: 7729-7737.

26. Kleinman HK, McCarvey ML, Hassell JR, Martin GR, Baron van Evercooren A, Dubois-Dalcq M. The role of laminin in basement membranes and in the growth, adhesion and differentiation of cells. Role of extracellular matrix in development. 1984; 14: 123-130.

27. Kleinman HK, Cannon FB, Laurie GW, Hassell JR, Aumailley M, Terranova VP, Martin GR, Dubois-Dalcq M. Biological activities of laminin. J Cell Biochem 1985; 27: 317-326.

28. Zagris $N$. Chung AE. Distribution and functional role of laminin during induction of the embryonic axis in the chick embryo. Differentiation 1990; 43: 81-86.

29. Shah KD, Gerber MA. Development of intrahepatic bile ducts in humans. Possible role of laminin. Arch Pathol Lab Med 1990; 114: 597-600.

30. Aumailley $M$, Wiedemann $H$, Mann $K$, Timpl $R$. Bînding of nidogen and the laminin-nidogen complex to basement membrane collagen type IV. Eur J Biochem 1989; 184: 241-248.

31. Kleinman HK, Ogle RC, Cannon FB, Little CD, Sweeney TM, Luckenbill-Edds L. Laminin receptors for neurite formation. Proc Natl Acad Sci USA 1988; 85: 1282- 1286.

32. Timpl $R$, Rohde $H$, Gehron Robey $P$, Rennart SI. Foidart JM, Martin GR. Laminin. A glycoprotein from basement membranes. J Biol Chem 1979; 254: 9933-9937.

33. Engel J, Odermatt E, Engel A, Madri JA, Furthmayr H, Rohde H, Timpl R. Shapes, domain organizations and flexibility of laminin and fibronectin, two multifunctional proteins of the extracellular matrix. $J \mathrm{Mol} B \mathrm{Biol}$ $1981 ; 150: 97-120$. 
34. Cooper AR, Kurkinen M. Taylor A, Hogan BLM. Studies on the biosynthesis of laminin by murine parietal endoderm cells. Eur J Biochem 1981; 119: 189-197.

35. Liotta LA, Rao CN, Wewer UM: Biochemical interactions of tumor cells with the basement membrane. Annu Rev Biochem 1986; 55: 1037-1057.

36. Paulsson M. Fujiwara S, Dziadek M. Timpl R, Pejler G, Backstrom G, Lindahl U, Engel J. Structure and function of basement membrane proteoglycans. Ciba- Found-Symp 1986; 124: 189-203.

37. Couchman JR, Austria MR, Woods A. Fibronectin-cell interactions. J Invest Dermatol 1990; 94: 7S. 4S.

38. Burgeson RE, Morris NP, Murray LW, Duncan KG, Keene DR, Sakai LY. The structure of type VII collagen. Ann N Y Acad Sci 1986; 460: 47-57.

39. Fegauer S, Seiler GR, Barrandon Y, Easley KW, Compton CC. Epithelial origin of cutaneous anchoring fibrils. J Cell Biol 1990; 111:2109-2115.

40. Leigh IM, Purkis PE, Bruckner-Tuderman L. LH 7.2 monocional antibody detects type VIl collagen in the sublamina densa zone of ectodermally-derived epithelia, including skin. Epithelia 1987; 1: 17-29.

41. Sakai LY, Keene DR, Morris NP, Burgeson RE. Type VII collagen is a major structural component of anchoring fibrils. J Cell Biol 1986; 103: 1577-1586.

42. Keene DR, Sakai LY, Lunstrum GP. Morris NP, Burgeson RE. Type Vll collagen torms an extended network of anchoring fibrils. J Cell Biol 1987; 104: 611-621

43. Wetzels RHW, Robben HCM, Leigh IM, Schaatsma E., Vooys GP, Ramaekers FCS. Distribution patterns of type VII collagen in normal and malignant human tissues. Am J Pathol 1991; 139: 451-459

44. Timpl $R$, Dziadek M, Fujiwara $S$, Nowackm $H$, Wick $G$. Nidogen, a new self aggregating basement membrane protein. Eur J Biochem 1983; 137: 455-456.

45. McCarthy JB, Basara ML, Palm SL, Sas DF, Furcht LT. The role of cell adhesion proteins-laminin and fibronectin-in the movement of malignant and metastatic cells. Cancer Metastatis Rev 1985; 4: 125-152.

46. Chiquet-Ehrismann R, Mackie EJ, Pearson CA, Sakakura T. Tenascin, an extracellular matrix protein involved in tissue interactions during fetal development and oncogenesis. Cell 1986; 47: 131-139.

47. Mackie EJ, Chiquet-Ehrismann R, Pearson CA, Inaguma $Y$. Tenascin is a stromal marker for epithelial malignancy in the mammary gland. Proc Natl Acad Sci USA 1987; 84: 4621-4625.

48. Vollmer G, Siegal GP, Chiquet-Ehrismann R, Lightner VA, Arnholdt H, Knuppen R. Tenascin expression in the human endometrium and in endometrial adenocarcinomas. Lab Invest 1990; 62: 725-730.

49. Howeedy AA, Virtanen I, Laitinen L, Gould NS, Koukoulis GK, Gould VE. Differential distribution of tenascin in the normal, hyperplastic and neoplastic breast. Lab invest 1990; 63: 798-806.

50. Kefalides NA, Alper R, Clark CC. Biochemistry and metabolism of basement membranes. int Rev Cytol 1979; $61: 169-228$.

51. Vracko R. Basal lamina scaffold-anatomy and significance for maintenance of orderly tissue structure. Am $J$ Pathol 1974; 77: 314-346.

52. Madri JA, Pratt BM, Yurchenco PD, Furthmayr $H$. The ultrastructural organization and architecture of basement membranes. In: Basement membranes and cell movement. CIBA Found symp 108 1984; 6-24.

53. Inove $S$, Leblond CP. Lauri GW. Ultrastructure of Reichert's membrane, a multilayered basement membrane in the parietal wall of the rat yolk sac. J Cell Biol 1983; 97: 1524-1537.

54. Laurie GW, Leblond CP, Inoue $S$, Martin GR, Chung AE. Fine structure of the glomerular basement membrane components to the lamina densa (basal lamina) and its extensions in both glomeruli and tubules of the rat kidney. Am J Anat 1984; 169: 463-481.

55. Inove S, Leblond CP. Three-dimensional network of cords: the main component of basement membranes. Am J Anat 1988; 181: 341-358.

56. Gorstein F. The dynamic extracellular matrix. Editorial. Hum Pathol 1988; 19: $751-752$.

57. Bosman FT, Cleutjens JPM, Beek C, Havenith MG. Basement membrane heterogeneity. Histochem J 1989; 21: $629-633$.

58. Damianov I. Heterogeneity of basement membranes in normal and pathologically altered tissues. Virchow's Arch A Pathol Anat 1990; 416; 185-188.

59. Leu FJ, Engvall E, Damjanov 1. Heterogeneity of basement membranes of the human genitourinary tract revealed by sequential immunofluorescence staining with monoclonal antibodies to laminin. $\mathrm{J}$ Histochem Cytochem 1986; 34: 483-489.

60. Schmoeckel $C$, Stolz W, Sakai LY, Burgeson RE, Timpl R, Krieg T. Structure of basement membranes in malignant melanoma and nevocytic nevi. J Invest Dermatol 1989; 92: 663-669.

61. Wetzels RHW, Holland $R$, van Haelst UJGM, Lane EB, Leigh IM, Ramaekers FCS. Detection of basement membrane components and basalcell keratin 14 in non- invasive and invasive carcinoma of the breast. Am $J$ Pathol 1989; 134: 571-579.

62. Liotta LA. Mechanisms of cancer invasion and metastasis. Volume 3: Influence of Tumor Development on the Host. In: Cancer Growth and Progression, edited by HE Kaiser Dordrecht: Kluwer Academic Publishers, 1989: 58-71.

63. Katz AM, Rosenthal D. Sauder DN. Cell adhesion molecules. Structure, function, and implication in a variety of cutaneous and other pathologic conditions. Intern J Dermatol 1991; 30: 153-160.

64. Niedbala MJ, Crickard $K$, Bernackj RJ. In vitro degradation of extracellular matrix by human ovarian carcinoma cells. Clin Exp Metastasis 1987; 5: 181-197. 
65. Dingemans KP. What's new in the ultrastructure of tumor invasion in vivo? Pathol Res Pract 1988; 183: 792808 .

66. Hynes RO. Integrins: a family of cell surface receptors. Cell 1987; 48: 549-554.

67. Virtanen I, Korhonen M, Kariniemi AL, Gould VE, Laitinen L, Ylänne J. Integrins in human cells and tumors. Cell Differ Dev 1990; 32: 215-227.

68. Cunningham BA. Cell adhesion molecules and the regulation of development. Am J Obstet Gynecol 1991; 164(4): 939-948

69. Takeichi M. Cadherin cell adhesion receptors as a morphogenetic regulator. Science 1991; 251: $1451-1455$.

70. Crossin KL. Cell adhesion molecules in embryogenesis and disease. Ann N Y Acad Sci 1991; 615: 172-186

71. Fleming S. Cell adhesion and epithelial differentiation. J Pathol 1991; 164: 95-100.

72. Danø K, Andreasen PA, Gröndahl-Hansen J, Kristensen P, Nielsen LS, Skriver L. Plasminogen activators, tissue degradation and cancer. Adv Cancer Res 1985; 44: 139-266.

73. Salo T, Liotta LA, Keski-Oja J, Turpeenniemi-Hujanen T, Tryggvason K. Secretion of basement membrane collagen degrading enzyme and plasminogen activator by transformed cells - role in metastasis. Int $J$ Cancer 1982; 30; 669-673.

74. Balian G, Click EM, Crouch $E$, Davidson JM, Bornstein P. Isolation of a collagen- binding fragment from fibronectin and cold-insoluble globulin. J Biol Chem 1979; 254: 1429-1433.

75. Liotta LA, Goldfarb RH, Brundage R, Siegel GP, Terranova VP, Garbisa S. Effect of plasminogen activator (urokinase), plasmin and thrombin on glycoprotein and collagenous components of basement membrane. Cancer Res 1981; 41: 4629- 4636.

76. Liotta LA, Wewer U, Rao NC, Schiffmann E, Stracke M, Guirguis R, Thorgeirsson U, Muschel R, Sobel M. Biochemical mechanisms of tumor invasion and metas tases. Adv Exp Med Biol 1988; 233: 161-169.

77. Kallioinen M, Autio Harmainen H, Dammert K, Risteli J, Risteli L. Basement membrane laminin and type IV collagen in various benign and malignant adnexal tumors of the skin: an immunohistochemical study. J Invest Dermatol 1984; 83: 276-280.

78. Gusterson BA, Warburton MJ, Mitchell D, Kraft N, Hancock WW. Invading squamous cell carcinoma can retain a basal lamina. An immunohistochemical study using a monoclonal antibody to type IV collagen. Lab Invest 1984; $51: 82-87$

79. Gusterson BA, Clinton S, Cough G. Studies of early invasive and intraepithelial squamous cell carcinoma using an antibody to type IV collagen. Histopathology 1986; 10:161-169.

80. Cam Y, Bellon G, Poulin G, Caron Y. Birembaut P. Distribution of type IV collagen in benign and malignant epithelial proliferations. An indirect immunofluorescence study on the breasts, the lungs and the skin. Invasion Metastasis 1984; 4: 61-72.

81. Havenith MG, van Zandvoort EHM, Cleutjens JPM, Bosman FT. Basement membrane deposition in benign and malignant nevo-melanocytic lesions: an immunohistochemical study with antibodies to type IV collagen and laminin. His topathology 1989; 15: 137-146.

82. Natali PG, Giacomini P. Bigotti G. Nicotra MR, Bellocci M, De Martino C. Heterogeneous distribution of actin, myosin, fibronectin and basement membrane antigens in primary and metastatic human breast cancer. Virchows Arch A (Pathol anat) 1984; 405: 69-83.

83. Willebrand D, Bosman FT, De Goeij AF. Patterns of basement membrane deposition in benign and malignant breast tumours. Histopathology 1986; 10: 1231-1241.

84. Barsky SH, Siegal GP, Jannotta F, Liotta LA. Loss of basement membrane components by invasive tumors but not by their benign counterparts. Lab Invest 1983; 49: 140-147.

85. Visser R, van der Beek JMH, Havenith MG, Cleutjens JPM, Bosman FT. Im munocytochemical detection of basement membrane antigens in the histopathological evaluation of laryngeal dysplasia and neoplasia. Histopathology 1986; 10: 171-180.

86. Erlandson RA, Cardon-Cardo C. Higgins PJ. Histogenesis of benign pleomorphic adenoma (mixed tumor) of the major salivary glands. Am J Surg Pathol 1984; 8: 803-820.

87. Toida M, Takeuchi J, Hara K, Sobue M, Tsukidate K, Goto K, Nakashima N. Histochemical studies of intercellular components of salivary gland tumors with special relerence to glycosaminoglycans, laminin and vascular elements. Virchows Arch (Path Anat) 1984; 403: 15-26.

88. Heikinheimo K, Morgan PR, Happonen RP, Stenman G, Virtanen I. Distribution of extracellular matrix proteins in odontogenic tumors and developing teeth. Virchows Arch B Cell Pathol 1991; 61:101-109.

89. Thesleff I, Ekblom P. Distribution of keratin and laminin in ameloblastoma. Comparison with developing tooth and epidermoid carcinoma. J Oral Pathol 1984; 13: 85-96.

90. Burtin P. Chavanel G, Foidart JM, Martin E. Antigens of the basement membrane and the peritumoral stroma in human colonic adenocarcinomas: an immunofluore scence study. Int J Cancer 1982; 30: 13-20.

91. Katoh R, Jasani B, Williams E.D. Hyalinizing trabecular adenoma of the thyroid. A report of three cases with immunohistochemical and ultrastructural studies. Histopatholy 1989; 15: 211-224.

92. Miettinen $M_{2}$ Virtanen I. Expression of laminin in thyroid gland and thyroid tumors: an immunohistologic study. Int J Cancer 1984; 34: 27-30.

93. Kendall $\mathrm{CH}$, Sanderson PR, Cope J, Talbot IC. Follicular thyroid tumors: a study of laminin and type IV collagen in basement membrane and endothelium. J Clin Pathol 1985; 38: 1100-1105.

94. Charpin C, Kopp F. Pourreau-Schneider $N$ et al. Laminin immunodetection in tumorous and non-tumorous disorders of human thyroid. Bull Cancer (Paris) $1985 ; 72: 6-15$. 
95. Bulletti C, Galassi A, Jasonni VM, Martinelli G, Tabanelli S, Flamigni C. Basement membrane components in normal, hyperplastic and neoplastic endometrium. Cancer 1988; 62: 142-149.

96. Vogel HP, Mendelsohn G. Laminin immunostaining in hyperplastic, dysplastic and neoplastic lesions of the endometrium and the uterine cervix. Obstet Gynecol 1987; 69: 794-799.

97. Furness PN, Lam EW. Patterns of basement membrane deposition in benign, pre-malignant and malignant endometrium. J Clin Pathol 1987; 40: 1320-1323.

98. Stenbäck F. Wasenius VM. Basement membrane structures in tumors of the ovary. Eur J Obstet Gyneco Reprod Biol 1985; 20: 357-371.

99. McComb RD, Bigner DD. Immunolocalization of laminin in neoplasms of the central and peripheral nervous systems. J Neuropath Exp Neurol 1985; 44: 242- 253.

100. Fleischmajer $R$, Timpl $R$, Dziadek M, Lebwohl M. Basement membrane proteins, interstitial collagens and fibronectin in neurofibroma. J Invest Dermatol 1985; 85: 54-59.

101. Miettinen M, Foidart JM. Ekblom P. Immunohistochemical demonstration of laminin, the major glycoprotein of basement membranes, as an aid in the diagnosis of soft tissue tumors. Am J Clin Pathol 1983; 79: 306.

102. Ogawa K. Oguchi M, Yamabe H, Nakashima $Y$, Hamashima $Y$. Distribution of collagen type IV in sott tissue tumors. An immunohistochemical study. Cancer 1986; 58: 269-277.

103. Richards CJ, Furness PN. Basement membrane continuity in benign, premalignant and malignant epithelial conditions of the uterine cervix. Histopathology 1990; 16: 47-52.

104. Uitto UT, Schwartz D, Vers A. Degradation of basement membrane collagen by neutral proteases from human granulocytes. Eur J Biochem 1980; 105: 409-417.

105. Haglund $C$, Nordling $S$, Roberts PJ, Ekblom $P$. Expression of laminin in pancreatic neoplasms and in chronic pancreatitis. Am J Surg Pathol 1984; 8: 669-676.

106. Haglund C, Roberts PJ, Nordling S. Expression of laminin in benign and malignant sclerosing lesions of extrahepatic bile ducts. J Clin Pathol 1989; 42: 927-930.

107. Gusterson BA, Warburton MJ, Mitchell D, Kraft N, Hancock WW. Invading squamous cell carcinoma can retain a basal lamina. An immunohistochemical study using a monoclonal antibody to type IV collagen. Lab Invest $1984 ; 51: 82-87$.

108. Stenbäck F, Wasenius VM. Basement membranes in ultraviolet-light induced skin lesions and tumors. Photodermatol 1985; 2: 347-358.

109. Gusterson BA, Clinton S, Cough G. Studies of early invasive and intraepithelial squamous cell carcinoma using an antibody to type IV collagen. Histopathology 1986; 10: 161-169.

110. van Cauwenberge Pierard GE, Foidart JM, Lapiere ChM. Immunohistochemical localization of laminin, type IV and type $V$ collagen in basal cell carcinoma. Br J of Dermatol 1983; 108: 163-170.

111. Cam $Y$, Bellon G, Poulin $G$, Caron $Y$, Birembaut $P$. Distribution of type IV collagen in benign and malignant epithelial proliferations. An indirect immunofluorescence study on the breasts, the lungs and the skin. Invasion Metastasis 1984; 4: 61-72.

112. Kallioinen M, Autio Harmainen H, Dammert K, Risteli J, Risteli L. Discontinuity of the basement membrane in fibrosing basocellular carcinomas and basosquamous carcinomas of the skin: an immunohistochemical study. J Invest Dermatol 1984; 82: 248-251.

113. Stenbäck F, Wasenius VM. Occurrence of basement membranes in pigment cell tumors of the skin. Relation to cell typo and clinical behaviour. J Cutan Pathol 1986; 13: 175-186.

114. Schmoeckel C, Stolz W, Sakai LY, Burgeson RE, Timpl R, Krieg T. Structure of basement membranes in malignant melanoma and nevocytic nevi. J Invest Dermatol 1989; 92: 663-668.

115. Kirkham N, Price ML, Gibson B, Leigh IM, Coburn P, Darley CR. Type VII collagen antibody LH 7-2 identifies basement membrane characteristics of thin malignant melanomas. J Pathol 1989; 157: 243-247.

116. Weber L, Wick G, Gebhart W, Krieg T, Timpl R. Basement membrane components outline the tumour islands in cylindroma. Br J Dermatol 1984; $111: 45-51$.

117. Kallioinen M. Immuno-electron microscope demonstration of the basement membrane components laminin and type IV collagen in the dermal cylindroma. J Pathol 1985; 147: 97-102.

118. Barsky SH, Hannah JB. Extracellular hyaline bodies are basement membrane accumulations. Am J Clin Pathol 1987; 87: 455-460.

119. Natali PG, Giacomini P, Bigotti G, Nicotra MR, Bellocci M, De Martino C. Heterogeneous distribution of actin, myosin, fibronectin and basement membrane antigens in primary and metastatic human breast cancer. Virchows Arch A (Pathol anat) 1984; 405: 69-3.

120. Birembaut $P$, Caron $Y$, Adnet JJ, Foidart JM. Usefulness of basement membrane markers in tumoural pathology. J Pathol 1985; 145: 283-296.

121. Charpin C, Lissitzky JC, Jacquemier J, Lavaut MN, Kopp F, Pourreau-Schneider N, Martin PM, Toga M. Immunohistochemical detection of laminin in 98 human breast carcinomas: a light and electron microscopic study. Hum Pathol 1986; 17: 355-365.

122. Cam $Y$, Caulet $T$, Bellon G, Poulin G, Legros M, Pytlinska M. Immunohistochemical localization of macromolecules of the basement membrane and the peritumoral stroma in human laryngeal carcinomas. $J$ Pathol 1984; 144: 35-44.

123. Carter RL, Burman JF, Barr L. Immunohistochemical localization of basement membrane type IV collagen in invasive and metastatic squamous carcinoma of the head and neck. J Pathol 1985; 147: 159-164. 
124. Sakr WA, Zarbo RJ, Jacobs JR, Crissman JD. Distribution of basement membrane in squamous cell carcinoma of the head and neck. Hum Pathol 1987; 18: 1043- 1050.

125. Havenith MG, Dingemans KP. Cleutjens JPM, Wagenaar SjSc. Bosman FT. Basement membranes in bronchogenic squamous cell carcinoma: an immunohis tochemical and ultrastructural study. Ultrastruct Pathol 1990; 14: 51-63.

126. Dingemans KP, Mooi WJ. Invasion of lung tissue by bronchogenic squamous cell carcinomas: interaction of tumor cells and lung parenchyma in the tumor periphery. Int J Cancer 1986; 37: 11-9.

127. Dingemans KP. Mooi WJ. Ultrastructure of tumor invasion and desmoplastic response of bronchogenic squamous cell carcinoma. Virchows Arch A Pathol Anat 1987; 411: 283-291.

128. Ten Velde GPM. Havenith MG, Volovics A, Bosman FT. Prognostic significance of basement membrane deposition in operable squamous cell carcinoma of the lung. Cancer 1991; 67: 3001-3005.

129. Ten Veide GPM, Thunnissen FBJM, Kuypers-Engelen BTMJ, Wagenaar Sj Sc, Bosman FT. Basement membranes in adenocarcinomas of the lung: an immunohistochemical and ultrastructural study. Submitted.

130. Wetzels RHW, Schaafsma HE, Leigh IM, Lane EB, Troyanovsky SM, Wagenaar SSC, Vooys GP, Ramaekers FCS. Laminin and type VII collagen distribution in different types of human lung carcinoma: correlation with expression of keratins 14,16, 17 and 18. Histopathology 1992; 20: 295-303.

131. Caselitz J, Schulze I, Seifert G. Adenoid cystic carcinoma of the salivary glands: an immunohistochemical study. J Oral Pathol 1986; 15: 308-318.

132. Meyer JR, Silverman S, Daniels TE, Kramer RH, Greenspan JS. Distribution of fibronectin and laminin in oral leukoplakia and carcinoma. J Oral Pathol 1985; 14:247-255.

133. Sauk JJ. Basement membrane continement of epithelial tumor islands in benign and malignant ameloblastomas. J Oral Pathol 1985; 14:307-314.

134. Havenith MG, Arends JW, Simon R, Volovics A, Wiggers T, Bosman FT. Type IV collagen immunoreactivity in colorectal cancer. Prognostic value of basement membrane deposition. Cancer 1988: 62; 2207-2211.

135. Forster SJ, Talbot IC, Clayton DG, Critchley DR. Tumour basement membrane laminin in adenocarcinoma of the rectum: an immunohistochemical study of biological and dinical significance. Int $\mathrm{J}$ Cancer 1986; 37: 813-817.

136. Daneker GW, Mercurio AM, Guerra L, Wolf B, Salem RR, Bagli DJ, Steele GD. Laminin expression in colorectal carcinoma varying in degree of differentiation. Arch Surg 1987; 122: 1470-1474.

137. Burtin P, Chavanel G, Foidart JM, Martin E. Antigens of the basement membrane and the peritumoral stroma in human colonic adenocarcinomas: an immunofluore scence study. Int J Cancer 1982; 30: 13-20.

138. Donato MF, Colombo $M$, Matarazzo M. Paronetto $F$. Distribution of basement membrane components in human hepatocellular carcinoma. Cancer 1989; 63: 272- 279.

139. Tabarin A, Bioulac-Sage P. Boussarie L, Balabaud C, De Mascarel A, Grimaud JA. Hepatocellular carcinoma developed on noncirrhotic livers. Sinusoids in hepatocellular carcinoma. Arch Pathol Lab Med 1987; 111: 174-180.

140. Schapers RFM, Pauwels RPE, Havenith MG, Smeets AWBG, van den Brandt PA, Bosman FT. Prognostic significance of type IV collagen and laminin immunoreactivity in urothelial carcinomas of the bladder. Cancer 1990; $66: 2583-2588$.

141. Conn IG, Crocker J, Wallace OMA, Hughes MA, Hilton CJ. Basement membranes in urothelial carcinoma. Br $\checkmark$ Ural 1987; 60: 536-542.

142. Hashimoto H, Sakashita S. Laminin- a basement membrane specitic glycoprotein in bladder carcinomas. Urol Int 1986; 41: 248-253.

143. Daher N, Abourachid H, Bove N, Petit J, Burtin P. Collagen IV staining pattern in bladder carcinomas, relationship to prognosis. Br J Cancer 1987; 55: 665-671.

144. Sinha AA, Gleason DF, Wilson MJ, Staley NA, Furcht LT, Palm SL, Reddy PK, Sibley RK, Martinez Hernandez A. Immunohistochemical localization of laminin in the basement membranes of normal, hyperplastic and neoplastic human prostate. Prostate 1989; 15: 299-313.

145. Bostwick DG, Brawer MK. Prostatic intraepithelial neoplasia and early invasion in prostate cancer. Cancer 1987; $59: 788-794$

146. Richards $\mathrm{CJ}$, Furness PN. Basement membrane continuity in benign, premalignant and malignant epithelial conditions of the uterine cervix. Histopathology $1990 ; 16 ; 47-52$.

147. Pitt MA, Hale RJ, Buckley $\mathrm{CH}$. The distribution of type IV collagen in invasive carcinoma of the uterine cervix. Histopathology 1992; 20: 139-143.

148. Stenbäck F, Wasenius VM, Risteli J, Risteli L. Basement membranes in progressing intraepithelial cervical neoplasia. An ultrastructural and immunohistochemical study with antibodies against human type IV collagen and laminin. Gynecol Obstet Invest 1985; 20: 158-166.

149. Stenbäck F, Risteli J, Risteli L, Wasenius VM. Basement membrane laminin and type IV collagen in endometrial adenocarcinoma: relation to differentiation and treatment. Oncology 1985; 42: 370-376.

150. Faber M, Wewer UM, Berthelsen JG. Liotta LA, Albrechtsen R. Laminin production by human endometrial stromal cells relates to the cyclic and pathologic state of the endometrium. Am J Pathol 1986; 124: 384-391.

151. Autio-Harmainen $\mathrm{H}$, Apaja-Sarkkinen M. Martikainen J, Taipale A, Rapola J. Production of basement membrane laminin and type IV collagen by tumors of striated muscle. Human Pathol 1986; 17: 1218-1224.

152. D'Ardenne AJ. Use of basement membrane markers in tumour diagnosis. J Clin Pathol 1989; 42: 429-57.

153. Bosman FT, Havenith MG, Cleutjens JPM. Basement membranes in cancer. Ultrastruct Pathol 19.85; $8: 291$. 


\section{CHAPTER 2}

\section{IMMUNOCYTOCHEMICAL DETECTION OF BASEMENT MEMBRANE ANTIGENS IN THE HISTOPATHOLOGICAL EVALUATION OF LARYNGEAL DYSPLASIA AND NEOPLASIA}

R. Visser, J.M.H. van der Beek, M.G. Havenith, J.P.M. Cleutjens, F.T Bosman Histopathology 1986; 10: 171-180 
In the histopathological assessment of epithelial laryngeal neoplasia it is of paramount importance to distinguish between severe dysplasia or carcinoma in situ and microinvasive carcinoma, because the optimal therapeutic approach is significantly different. The diagnosis depends on the presence or absence of invasion of neoplastic epithelial cells into the adjacent mesenchymal stroma. In borderline situations it is, however, often difficult to establish infiltrative expansion of epithelial tumor cells into the adjacent stroma without the help of special staining procedures.

Conventional methods to overcome this problem are reticulin and PAS stains for basement membrane identification, and serial sections. Even when these techniques are applied, histopathologists are confronted from time to time with laryngeal biopsies, showing severe epithelial dysplasia with irregular budding of epithelial cells, in which microinvasive growth is difficult to establish or exclude.

The laryngeal basement membrane, as elsewhere in the body, is composed of intrinsic components, including type IV collagen and laminin and extrinsic components such as type $V$ collagen and fibronectin (1). The intrinsic components are produced by the adjacent epithelial cells. Immunohistochemical procedures using antibodies specific for laminin and type IV collagen allow selective staining of the basement membrane and therefore evaluation of its composition and continuity (2). Against this background we studied the epithelial basement membrane in a series of laryngeal biopsies with epithelial dysplasia of varying severity, and neoplasia. The results indicate that basement membranes, in the absence of inflammation, form a continuous structure at the epithelial-stromal interface in normal and hyperplastic mucosa, but are progressively disrupted in some cases of carcinoma in situ and in all cases of invasive carcinoma. This phenomenon may be potentially useful for the histopathological diagnosis of laryngeal neoplasms.

\section{$2.2 \quad$ MATERIALS AND METHODS}

\subsubsection{Case material}

From the files of the Department of Pathology of the University Hospital (Maastricht) and the Netherlands Cancer Institute (Amsterdam) we collected 27 laryngeal biopsies with simple hyperplasia, dysplasia, carcinoma in situ and invasive carcinoma. All tissues had been fixed in $4 \%$ neutral buffered formaldehyde and were paraffin embedded. On haematoxylin and eosin stained sections the lesions were classified independently by two pathologists according to the criteria outlined in Table 1.

Table 1. Histopathological criteria for classification

\begin{tabular}{ll}
\hline Simple hyperplasia & $\begin{array}{l}\text { Epithelial hyperplasia } \\
\text { Hyper-and parakeratosis } \\
\text { Increased mitotic activity in the basal cell layer } \\
\text { No cytonuclear atypia }\end{array}$ \\
Dysplasia & $\begin{array}{l}\text { acanthosis } \\
\text { Hyper-and parakeratosis } \\
\text { Moderate cellular and nuclear atypia } \\
\text { Dyskeratosis } \\
\text { Increased number of mitoses }\end{array}$ \\
Carcinoma in situ & $\begin{array}{l}\text { Severe cellular atypia } \\
\text { Marked nuclear hyperchromasia and pleomorphism } \\
\text { Numerous mitoses in all cell layers } \\
\text { Absence of intiltrating growth }\end{array}$ \\
&
\end{tabular}


Based on these criteria the cases were diagnosed as hyperplasia $(n=8)$, dysplasia $(n=7)$, carcinoma in situ $(n=8)$ and invasive carcinoma $(n=4)$. In addition, three lymph nodes with metastases of squamous cell carcinoma of the larynx were studied.

Serial $4 \mu \mathrm{m}$ sections were cut and stained according to the periodic-acid-Schiff method (PAS) and the Jones method for reticulin.

\subsubsection{Immunohistochemistry}

Immunocytochemical detection of type IV collagen and laminin in 17 biopsies with hyperplasia, dysplasia, carcinoma in situ and invasive carcinoma and type IV collagen in 11 biopsies with hyperplasia and dysplasia was performed using an indirect peroxidase labeled antibody method. A rabbit anti-rat laminin antiserum was obtained from Dr. A. Martinez-Hernandez (Hahnemann Medical School, Philadelphia). This antiserum was raised against laminin isolated from the rat EHS sarcoma. The specificity of this antiserum has been described previously (3). In addition, we excluded cross reactivity with type I, III and V collagens, by solid phase enzyme immunoassay performed as described previously (4). Human type IV collagen was isolated from placenta using the method described by Sage, Wordberg \& Bronstein (5). Purity of this preparation was monitored by sodium dodecyl sulphate polyacrylamide gel electrophoresis (SDS-PAGE). Antibodies were induced in rabbits by multiple intradermal injections with the antigen, emulsified with Freund's complete adjuvant. The titre of the antiserum was monitored by solid phase enzyme immunoassay. Antiserum specificity was analyzed by SDS-PAGE and immunoblotting according to Towbin, Staehelin \& Gordin (6). As second antibody a peroxidase labeled goat anti-rabbit antiserum was used (Miles. Yeda lot no. 456).

Immunocytochemistry was performed on rehydrated paraffin sections. Before incubation, the sections were exposed to pepsin as described by Barsky et al. (2).

The incubations ( $60 \mathrm{~min}$ at room temperature) were done with antiserum appropriately diluted in phosphate buffered saline (PBS) with $1 \%$ bovine serum albumin. After incubation with primary antiserum and conjugate the sections were repeatedly washed in PBS. Peroxidase activity was visualized using diaminobenzidine. Specificity of the obtained immune reaction was controlled by staining of parallel sections with preimmune serum or with immune serum preincubated with the appropriate antigen. In these control sections immunoreactivity was not detected.

\subsection{RESULTS}

The results of the histological classification and basement membrane immunocytochemistry are summarized in Table 2 . Unlike routine stains, sections processed with the immunoperoxidase method showed clearly detectable basement membranes using laminin and type IV collagen antisera. Basement membranes were prominently stained at the junction between epithelium and stroma, and around blood vessels and muscle fibres (Figure 1). In all cases immunoreactivity for type IV collagen and laminin showed an identical pattern, although usually laminin staining was less intense. As expected, the epithelial basement membrane staining was continuous in cases of hyperplasia and dysplasia (Figure 2). In one case of hyperplasia with severe inflammation the basement membrane showed several small, well defined interruptions strictly confined to areas of epithelial invasion by inflammatory cells (Figure 3). 
Table 2. Histological and immunocytochemical results

\begin{tabular}{|c|c|c|c|}
\hline No & Histological diagnosis & Inflammation" & $\mathrm{BM}^{*}$ \\
\hline 1 & Hyperplasia & + & intact \\
\hline 2 & Hyperplasia & + & intact \\
\hline 3 & Hyperplasia & + & intact \\
\hline 4 & Hyperplasia & + & intact \\
\hline 5 & Hyperplasia & + & intact \\
\hline 6 & Hyperplasia & + & intact \\
\hline 7 & Hyperplasia & ++ & intact \\
\hline 8 & Hyperplasia & $+t$ & $\mathrm{Fl}^{\mathrm{x}}$ \\
\hline 9 & Dysplasia & + & intact \\
\hline 10 & Dysplasia & + & intact \\
\hline 11 & Dysplasia & + & intact \\
\hline 12 & Dysplasia & + & intact \\
\hline 13 & Dysplasia & ++ & $\mathrm{Fl}^{\mathrm{x}}$ \\
\hline 14 & Dysplasia & ulceration & interrupted ${ }^{x}$ \\
\hline 15 & Dysplasia & ulceration & interrupted ${ }^{x}$ \\
\hline 16 & Carcinoma in situ & + & intact \\
\hline 17 & Carcinoma in situ & ++ & intact \\
\hline 18 & Carcinoma in situ & ++ & intact \\
\hline 19 & Carcinoma in situ & + & $\mathrm{FI}$ \\
\hline 20 & Carcinoma in situ & + & $\mathrm{FI}$ \\
\hline 21 & Carcinoma in situ & - & intact \\
\hline 22 & Carcinoma in sity & + & $\mathrm{FI}$ \\
\hline 23 & Carcinoma in situ & - & $\mathrm{FI}$ \\
\hline 24 & Invasive carcinoma & - & interrupted \\
\hline 25 & Invasive carcinoma & $\bar{f}$ & interrupted \\
\hline 26 & Invasive carcinoma & + & interrupted \\
\hline 27 & Invasive carcinoma & + & interrupted \\
\hline
\end{tabular}

$\mathrm{FI}_{2:=}$ focal interruptions;

- = density of inflammatory infiltrate

$-=$ no infammatory infiltrate;

$t=$ moderately dense;

$++=$ dense, almost invariably accompanied by intraepithelial inflammatory cells;

' in all cases type IV collagen and laminin showed identical staining patterns:

${ }^{x}$ basement membrane interruptions were strictly limited to sites of inflammatory disruption of the epithelium.

In all cases of invasive carcinoma, classified by conventional methods, the basement membrane showed extensive and irregular discontinuities as reflected by absence of laminin and type IV collagen staining. Nests of tumour cells were often completely or partially devoid of surrounding basement membrane (Figure 4). A remarkable observation was the presence of laminin and type IV collagen in the cytoplasm of some neoplastic epithelial cells.

Expression of intracytoplasmic type IV collagen and laminin in tumour cells was also observed in metastatic foci in regional lymph nodes (Figure 5). In addition, in metastases, incomplete formation of basement membrane was occasionally observed.

The most important findings concerned the cases of carcinoma in situ in which microinvasive growth was difficult to prove or exclude on the basis of conventional stains. By immunocytochemical staining focal discontinuities in basement membranes were detected in four of these cases. In none of these cases the basement membrane interruptions were related to an inflammatory reaction. 
In all mucosae, basement membranes occur at the interface between epithelium and stroma and furthermore around capillaries, muscle fibres and glandular structures. Basement membranes are not found around lymphatic vesseis (2).

As shown by electron microscopy, basement membranes consist of an electron lucid layer (lamina rara), which is in close proximity to the basal cell surface, and an electron dense layer (lamina densa). Biochemically, basement membranes are composed of intrinsic and extrinsic components (1).

Type IV collagen and laminin are intrinsic components, occurring only in basement membranes and deposited by the adjacent cell. Substances such as fibronectin and type $V$ collagen occur also in other structures, are not exclusively produced by the adjacent cells, and are therefore regarded as extrinsic components. In recent years many studies have demonstrated that basement membrane interruptions are characteristic of infiltrative growth in carcinoma (7).

The study of basement membranes in laryngeal neoplasia is not entirely new. Schenk (8) investigated the tumour/stroma relationship in invasive squamous cell carcinomas of the larynx at the ultrastructural level. He found that basement membranes are produced by malignant epithelial cells and concluded that penetration of basement membranes by tumour cells is not conclusive evidence of invasive carcinoma, but may be an indication of increased catabolic cell surface activity. Another interesting finding in this study was the inappropriate formation of basement membrane material in spaces created by invagination of the plasma membrane into the cytoplasm. These observations largely agree with our results. In our material we noted intact membranes in normal laryngeal mucosa and in cases of simple epithelial hyperplasia and dysplasia without severe inflammation. In the cases with severe inflammation there were several rather regular and small interruptions of basement membranes, related to the site of inflammation and the presence of intraepithelial inflammatory cells. This pattern of basement membrane disintegration was distinctly different from the more irregular pattern of basement membrane interruptions in obviously invasive carcinoma.

In four cases of carcinoma in situ, interruptions of the basement membrane were found. In three of these cases moderately active inflammation was aiso observed but not in the area where basement membrane interruptions were detected. This finding can be explained by assuming that decreased assembly or increased breakdown of basement membranes, or both, may be early signs of imminent infiltrative growth. Additional studies on larger series of borderline cases and including long term follow-up data will have to be performed to establish the biological significance of basement membrane interruptions in morphologically non-invasive carcinoma in situ. Four cases of carcinoma with extensive invasive growth showed advanced and irregular interruptions of the basement membrane in areas of invasion.

Strikingly, also in foci of metastatic cancer in regional lymph nodes we found tumour cells with inappropriate intracytoplasmic expression of laminin and type IV collagen.

These results agree largely with those of Cam et al. (9), who found weak and irregular patterns of basement membranes for laminin and type IV collagen immunofluorescence in undifferentiated carcinomas and in differentiated carcinomas. The immunofluorescence staining was almost entirely absent at the periphery of the infiltrating tumour trabeculae. On the other hand, there was well defined linear staining of basement membranes around nests of well differentiated squamous cell carcinoma.

The mechanisms underlying basement membrane penetration during neoplastic invasive growth are complex and not completely understood. Basement membrane penetration may be due to deficient synthesis of basement membrane components or by the inability of the neoplastic cell to assemble the components into a structured membrane. This latter mechanism is supported by the intracytoplasmic appearance of laminin and type IV collagen. An alternative possibility is proteolytic breakdown of basement membranes by the 
invasive neoplastic cells. Evidence in support of this mechanism was provided by Liotta et al. (7) who demonstrated production of type IV collagen specific collagenases by neoplastic cells in several types of carcinoma.

In conclusion, we have demonstrated that the epithelial basement membrane shows characteristic interruptions in some cases of carcinoma in situ and in invasive carcinoma of the larynx. We therefore postulate that immunocytochemical detection of specific basement membrane components, laminin and/or type IV collagen, may be a valuable tool for the determination of early invasive growth.

Additional studies on larger series of laryngeal neoplasms, inciuding long term follow up, are necessary to establish the practical value of this approach for the histopathological classification of laryngeal neoplasia. 
1. Martinez-Hernandez A, Amenta P. The basement membrane in pathology. Lab invest 1983; 48: 656-678.

2. Barsky SH, Rao NC, Restrepo C, Liotta LA. Immunocytochemical enhancement of basement membrane antigens by pepsin: applications in diagnostic pathology. Am J Clin Pathol 1984; 82(2): 191-194.

3. Martinez-Hernandez A, Amenta PS. Laminin-secreting yolk sac carcinoma of the rat. Lab Invest 1982; 47 : 247-257.

4. Bosman FT. Some recent developments in immunocytochemistry. Am J Clin Path 1983; 15: 189-200.

5. Sage H, Wordberg RG, Bornstein P. Structural studies on human type IV collagen, $\downarrow$ Biol Chem 1979; 254 ; 9893-9900.

6. Towbin H, Staehelin T, Gordin J. Electrophoretic transfer of proteins from polyacrylamide gels to nitrocellulose sheets. Proc Natl Acad Sci USA 1979; 76: 4350-354.

7. Liotta LA, Rao CN, Barsky SH. Tumor invasion and the extracellular matrix. Lab Invest 1983; 49: 636-650.

8. Schenk P. Ultrastrukturelle Basallamina-alterationen an der Tumor-Stromagrenze von invasive Larynxkarzinomen. Laryngologie, Rhinologie, Otologie (Stuttgart) 1981; 60: 573-576.

9. Cam Y, Caulet T, Bellon G, Poulin G, Legros M, Pytlinska M. Immunohistochemi cal localization of macromolecules of the basement membrane and the peritum oral stroma in human laryngeal carcinomas. J Pathol 1984; 144: 35-44. 


\section{L.EGENDS TO THE FIGURES}

Figure 1 Normal laryngeal epithelium. Basement membrane visualized with anti-type IV collagen. Note the unstained lymphatic vessels (arrow). x63.

Figure 2 Epithelial dysplasia with an infact basement membrane. Anti-type IV collagen. $x 63$.

Flgure 3 Hyperplasia with severe inflammation. Note severe intraepithelial leucocytes and small, well defined basement membrane interruptions. Anti-type N collagen. $\times 250$.

FIgure 4 Invasive squamous cell carcinoma. Tumor nests are almost completely devoid of surrounding basement membrane (anti-type IV collagen). Note basement membrane around capillaries $\times 250$.

Figure 5 Regional lymphnode metastasis of laryngeal squamous cell carcinoma. Several tumor cells show cytoplasmic immunoreactivity (arrows). Anti-type IV collagen. $\times 400$.

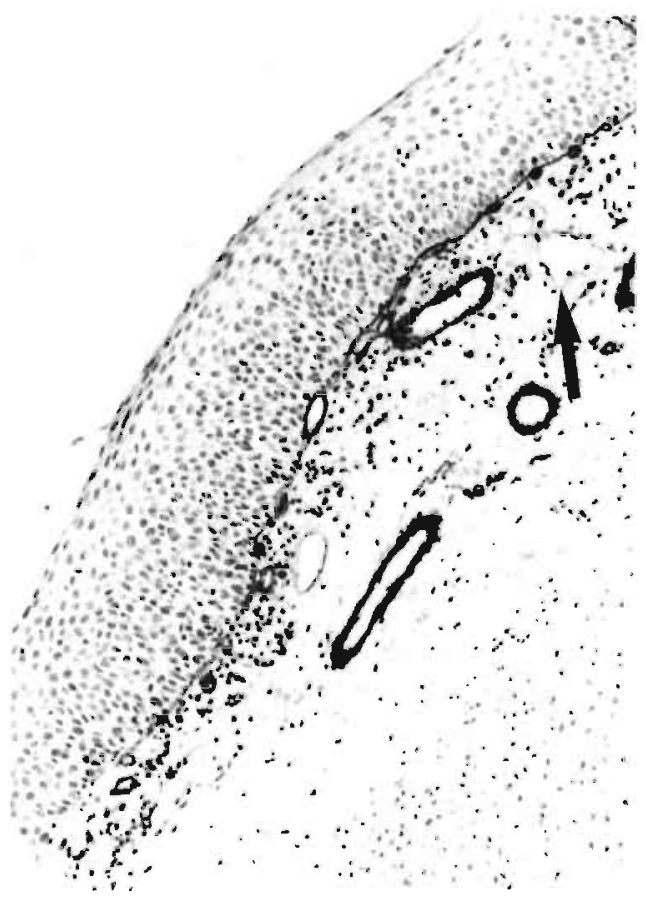

Figure 1

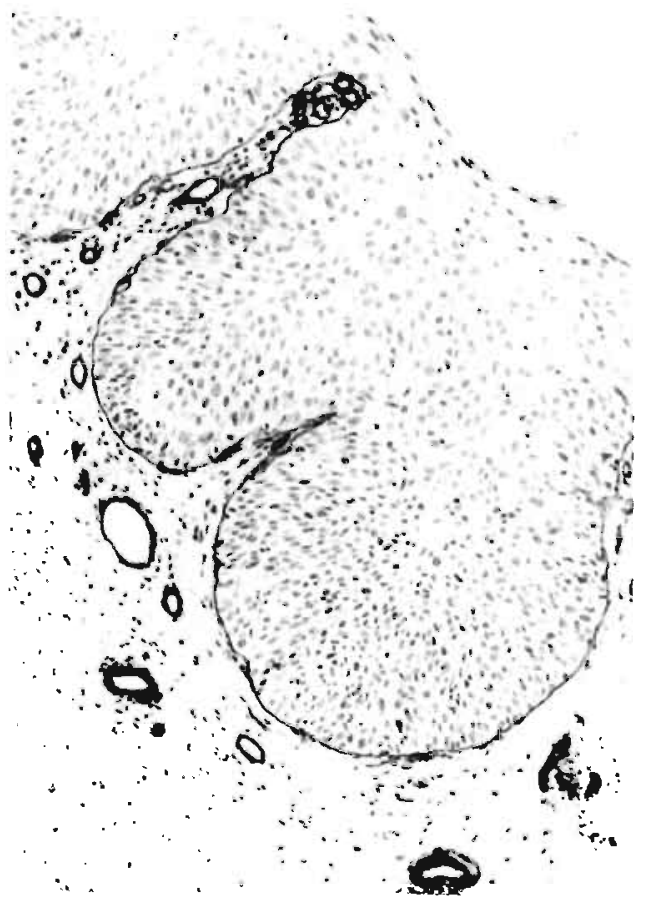

Flgure 2 




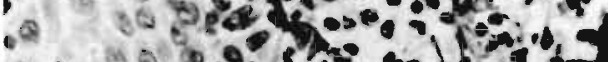

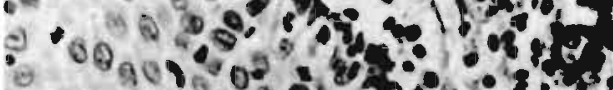

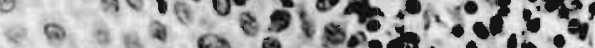

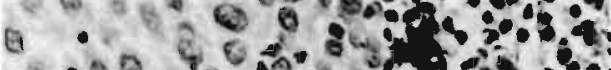



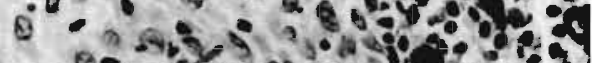

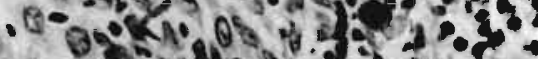

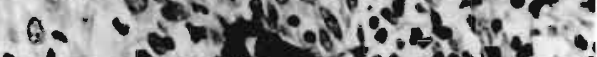
- it है



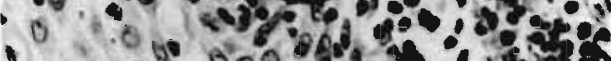

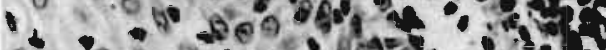
8. 0.0 i

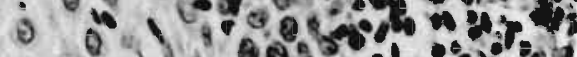




- Q. $\because$ \%

\section{Figure 3}

os 50.03 C. a 0 का 10 - vedt (8) Non, 501123.28 $4.0600 \%$ 1500 $0=0.0 \%$ $2600^{3} 3$ 1 .

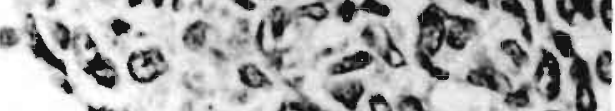

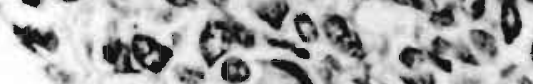

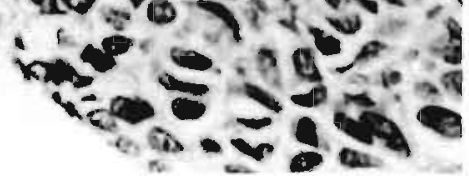

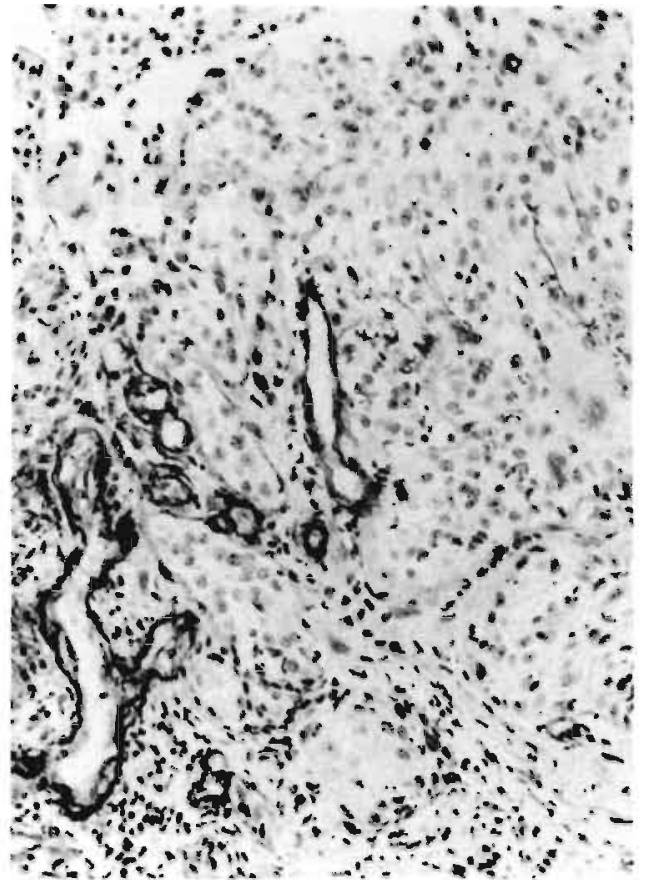

Figure 4 



\section{CHAPTER 3}

\section{BASEMENT MEMBRANE PATTERNS IN BORDERLINE TUMORS OF THE OVARY.}

An immunohistochemical study with antibodies to laminin and type IV collagen.

R Visser, JW Arends, FT Bosman

Int. J. Gyn. Cancer; accepted for publication 
Basement membrane immunohistochemistry has proven to be a useful tool in the differentiation between benign lesions, in-situ carcinoma and invasive neoplastic disease.

Its importance in diagnostic histopathology has already been evaluated in a variety of studies (1-5). Few studies so far, however, have been devoted to the detection of basement membrane components in ovarian neoplasms $(6,7)$. This is striking in view of the existence of a category of tumors of borderline malignancy in this organ, where the study of basement membranes in connection with invasive growth might be useful.

Tumors of borderline malignancy have a limited potential for progression towards a frankly malignant lesion and their histological features which include cytonuclear atypia, epithelial stratification and loss of cell polarity with absence of invasive growth $(8,9)$, do not allow a reliable prediction of tumor behaviour. The histological distinction between borderline tumors and benign cystadenomas or malignant cystadenocarcinomas appears to be difficult because invasive growth cannot always be established unequivocally, especially in mucinous tumors and because the cytonuclear features of malignancy are insufficiently discriminative.

We therefore studied the patterns of type IV collagen and laminin immunoreactivity in epithelial tumors of borderline malignancy in relation to those of overtly benign and malignant epithelial neoplasms of the ovary. Our working hypothesis was, based upon basement membrane morphology, that a distinction might be made between lesions with a continuous and those with a discontinuous basement membrane. Further follow-up studies might then reveal whether or not a difference in behaviour might exist between these categories.

\subsection{MATERIALS AND METHODS}

\section{Case material}

From the files of our department and the department of Pathology of the De Wever Hospital, Heerlen, we collected 20 cases of borderline ovarian lesions of the serous as well as the mucinous type, 5 cases of mucinous and 5 of serous ovarian cystadenoma, 4 cases of serous ovarian cystadenocarcinoma and 10 of mucinous cystadenocarcinoma.

All tissue specimens were routinely fixed in $4 \%$ buffered formaldehyde and paraffin embedded. Paraffin sections were stained with haematoxylin and eosin (H\&E).

\subsubsection{Immunohistochemistry}

Immunohistochemistry was carried out using an indirect immunoperoxidase technique. Paraffin sections $(3 \mu \mathrm{m})$ were deparaffinized, blocked for endogenous peroxidase with $0.3 \%$ hydrogen peroxide in methanol, rehydrated and washed $3 \times 5$ minutes with Trizma buffered saline (TBS). The sections were pretreated with $0.1 \%$ pepsin (Boehringer) in $1 \mathrm{~N} \mathrm{HCl}, 30$ minutes at room temperature (RT) to enhance immunoreactivity (10). Subsequently the sections were washed $3 \times 5$ minutes with TBS and incubated with polyclonal antibodies against type IV collagen (diluted 1:250 in TBS with 1\% BSA) or laminin (diluted 1:100) during one hour at RT in a moist chamber. Both antisera were raised in rabbits. The immunospecificity of these antisera has been reported elsewhere $(11,12)$. After washing with TBS the sections were incubated with peroxidase labeled rabbit anti-mouse antibodies (DAKOPATTS) for 1 hour at RT.

Visualization of the antigen-antibody complex was performed with diaminobenzidine as chromogen. The intensity of the staining reaction was enhanced using imidazole. Immunoreactivity was assessed using the basement membrane of vascular structures as internal positive controls. 
In six cases of the ovarian tumors insufficient immunoreactivity was obtained; these were excluded from the study. This resulted in 14 tumors with borderline malignancy that were available for immunohistochemical study. In these tumors of borderline malignancy and in the other ovarian tumors, the staining intensity of the vascular basement membrane, which served as internal controls, was sufficient for reliable basement membrane evaluation.

\subsection{RESULTS}

In general, immunostaining for laminin was somewhat less intense than that for type IV collagen, but for the two antigens no significant differences in staining pattern were observed. Also around spindle shaped stromal cells type IV collagen and laminin immunoreactivity was noted but in irregular patches.

\subsubsection{Cystadenoma}

The basement membrane pattern in mucinous and serous cystadenomas was similar. We observed a continuous and regularly structured basement membrane underlying epithelial cells that lined cysts and papillary projections (Fig.1a). In these benign tumors at several locations we found epithelial budding into the stroma with discrete and regular discontinuities of the basement membrane (Fig. ib).

\subsubsection{Cystadenocarcinoma}

The basement membrane staining pattern of cystadenocarcinomas differed from that in cystadenomas. In many areas intact basement membranes were found between tumor cells and the surrounding stroma. In the H\&E stained sections, such areas usually could be recognized as invasive growth (Fig.2a and $2 \mathrm{~b}$ ). In all tumors areas occurred with fragmentation or complete absence of basement membrane components around clusters of malignant epithelial cells (Fig.3). Laminin immunoreactivity showed a similar pattern but could also be demonstrated in the cytoplasm of some tumor cells.

\subsubsection{Tumors of borderline malignancy}

These lesions predominantly showed a continuous basement membrane at the border between atypical epithelial cells and the underlying stroma (Fig.4a).

Discrete discontinuities in type IV collagen and laminin staining were found at the tips of epithelial buds, which occasionally extended from the epithelia covering the cysts into the surrounding stroma, as also noted in cystadenomas.

In four tumors, however, small areas occurred with extensive and irregular interruptions of the basement membrane, comparable to the pattern of invasion in adenocarcinomas(Fig.4b).

Therefore, based upon basement membrane patterns, borderline malignant ovarian tumors appeared to consist of two distinct subgroups: one with a basement membrane pattern identical to cystadenoma and a second with a basement membrane pattern resembling that of cystadenocarcinoma.

\subsection{DISCUSSION}

Borderline malignancies represent a category of tumors which in microscopic appearance as well as in clinical outcome appear to be on the borderline between benign and malignant. In theory, borderline tumors might be explained in two different ways. They might constitute a separate entity with their own characteristics in terms of morphology and 
clinical behaviour. Alternatively, this category may be regarded as to consist of lesions, which on the basis of histomorphology cannot be classified with regard to their behaviour. In the latter case, the borderline tumor group should consist of two groups, one with an essentially benign and an one with an essentially malignant character.

Since one of the essential features of malignancy is invasive growth, we regarded it worthwhile to study the integrity of the basement membrane. We hypothesized that if borderline tumors constitute a distinct and uniform entity a uniform basement membrane pattern would be found. If, however, the borderline group contains essentially benign and essentially malignant tumors, this would be reflected by differences in basement membrane patterns.

Although basement membranes in cancer have been studied extensively, relatively few studies have been devoted to basement membrane qualities in borderline tumors of the ovary. Frappart et al (7) investigated only three cases of borderline tumors in a series of epithelial ovarian tumors and found discontinuous immunofluorescence at the basement membrane region using antibodies directed against laminin. They concluded that these discontinuities in the basement membrane indicated a beginning of infiltrative growth.

Contrasting with the findings of Frappart et al, we observed regular and continuous basement membranes in the majority of the borderline tumors in a pattern identical to that in cystadenomas. Basement membrane interruptions were seen, but in a rather regular and predictable way, surrounding epithelial buds or small epithelial islands in the stroma. Fox (8) previously described these invaginations in serous and mucinous tumors of borderline malignancy and emphasized the difficulties in differentiating these from stromal invasion.

In 4 of our 14 tumors, originally diagnosed as of borderline malignancy, areas with extensive and irregular interruptions of the basement membrane were found. As this pattern was similar to that in invasive areas in cystadenocarcinoma, we are tempted to conritito that thoso four bordorlino tumors contairied luui ur livasive growin and inererore should be regarded as adenocarcinoma.

On the basis of these findings we propose that borderline ovarian tumors are not a distinct entity but consist of a group of intrinsically benign and a group of intrinsically malignant tumors.

Further immunohistochemical studies on larger patient series and including follow up data are necessary to assess the clinical validity of this assumption. 
1. D'Ardenne AJ. Use of basement membrane markers in tumour diagnosis. J Clin Pathol $1989 ; 42: 429-57$.

2. Bosman FT, Havenith MG, Cleutjens JPM. Basement membrane in cancer. Ultrastruct Pathol 1985; 8: 291304.

3. Martinez-Hernandez A, Amenta PS. The basement membrane in pathology. Lab Invest $1983 ; 6 ; 656-78$.

4. Storad CJ. Membrane changes in epithelial neoplasms. JAMA 1984; 252: 1665-1666.

5. Bosman FT, Cleutjens JPM, Beek C, Havenith MG. Basement membrane heterogeneity. Histochem J 1989; 21: 629-33.

6. Stenbäck F. Wasenius VM. Basement membrane structures in tumors of the ovary. Eur J Obstet Gynecol Reprod Biol 1985; 20: 357-371.

7. Frappart L, Agard C, Hu Chi Lin, Grimaud JA, Palayer C, Rochet Y, Bremont A. Les membranes basales des tumeurs epitheliales de l'ovaire. J Gynecol Obstet Biol Reprod 1984; 13: 117-23.

8. Fox $\mathrm{H}$. The concept of borderline malignancy in ovarian tumours: a reappraisal. In: Current topics in pathology Berlin: Springer, Vol 78: 1989: 111-34.

9. Serov SF, Scully RE, Sobin LH. International classification of fumors. No 9. Histologic typing of ovarian tumours. Geneva: World Health Organization, 1973.

10. Barsky SH, Rao NC, Restrepo C, Liotta LA. Immunocytochemical enhancement of basement membrane antigens by pepsin; applications in diagnostic pathology. Am J Clin Pathol 1984; 822: 191-194.

11. Havenith MG. Cleutjens JPM, Beek C, v.d.Linden E, de Goeij AFPM, Bosman FT. Human specific anti type IV collagen antibodies, characterization and immunohistochemical application. Histochemistry 1987; 87: 123128.

12. Havenith MG, Dingemans KP, Cleutjens JPM, Wagenaar SjSc, Bosman FT. Basement membranes in bronchogenic squamous cell carcinoma: an immunohistochemical and ultrastructural study. Ultrastruct Pathol $1990 ; 14(1): 51-63$. 


\section{LEGENDS TO THE FIGURES}

Flgure 1a. Serous cystadenoma with intact basement membrane, immunoreactive for type IV collagen (125x).

Figure 1b. Mucinous cystadenoma with focal absence of the basement membrane around epithelial budding (arrow). Type IV collagen, immunoperoxidase (250x).

Figure 2. Cystadenocarcinoma. Two consecutive sections, H\&E (a) and immunostained for type IV collagen (b). The H\&E stained section suggests tumor invasion, whereas the type IV collagen immunostaining (b) shows an intact basement membrane between tumor and stroma $(63 \mathrm{x})$.

Figure 3. Cystadenocarcinoma. Periphery of the tumor. Irregular, fragmented basement membrane material at the interface between tumor and stroma. Type IV collagen immunoperoxidase (250x).

Figure 4. Borderline malignant ovarian tumors. a: Epithelium lined with a continuous basement membrane (type IV collagen immunoperoxidase, 63x). b: Atypical epithelia only focally lined with a basement membrane (arrows; type IV collagen, 63x).

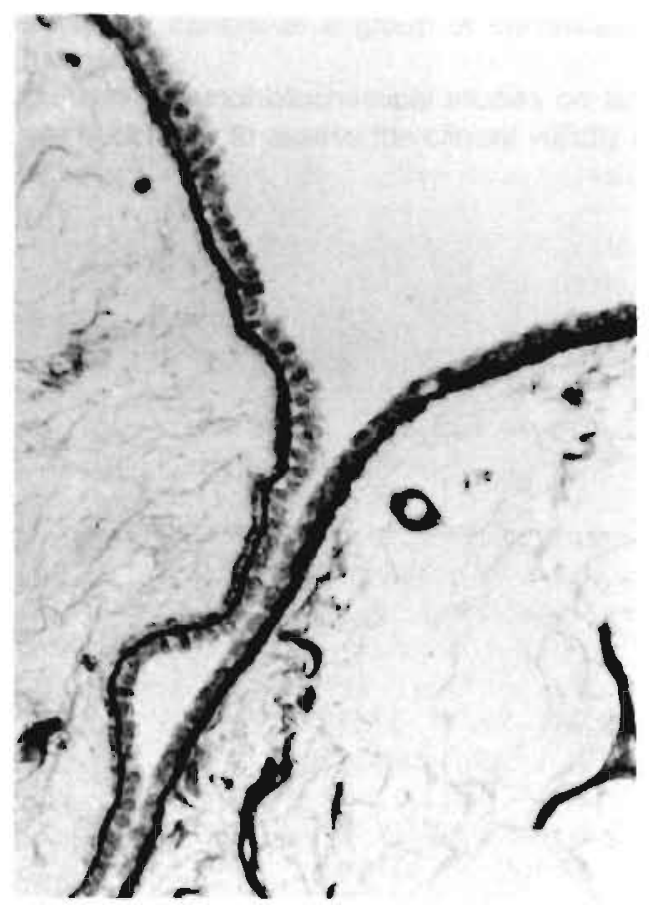

Figure 1a

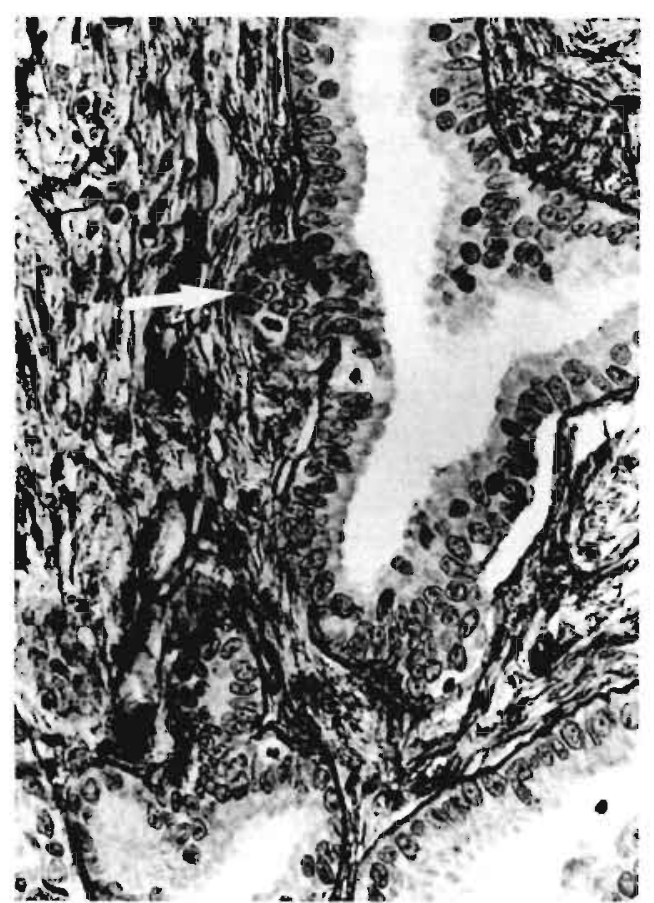

Figure 1b 


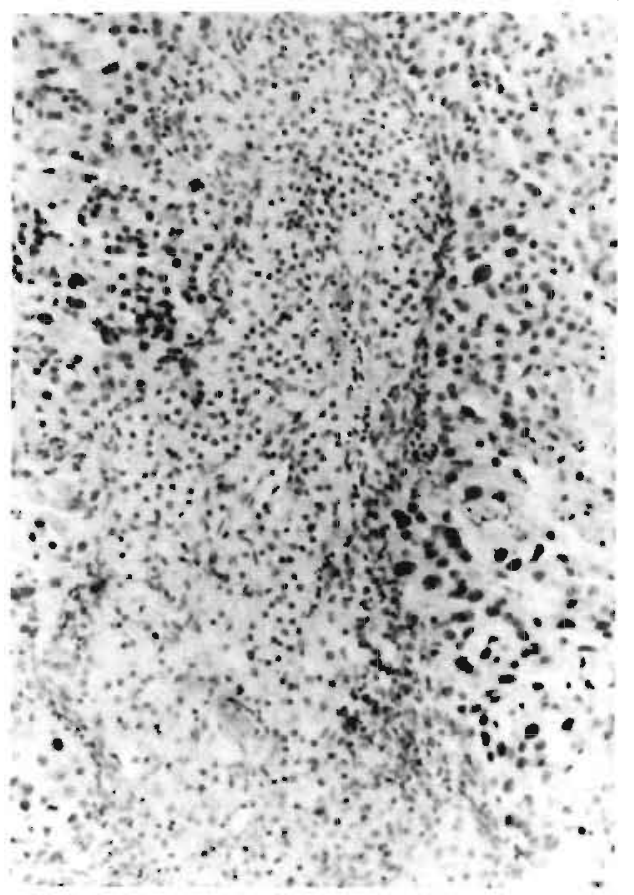

Figure 2a

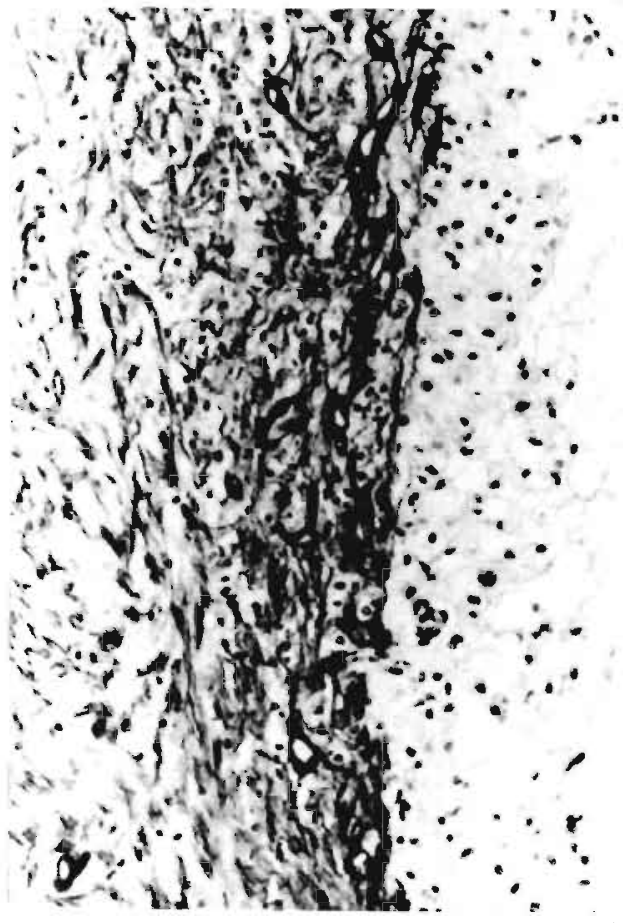

Figure 3

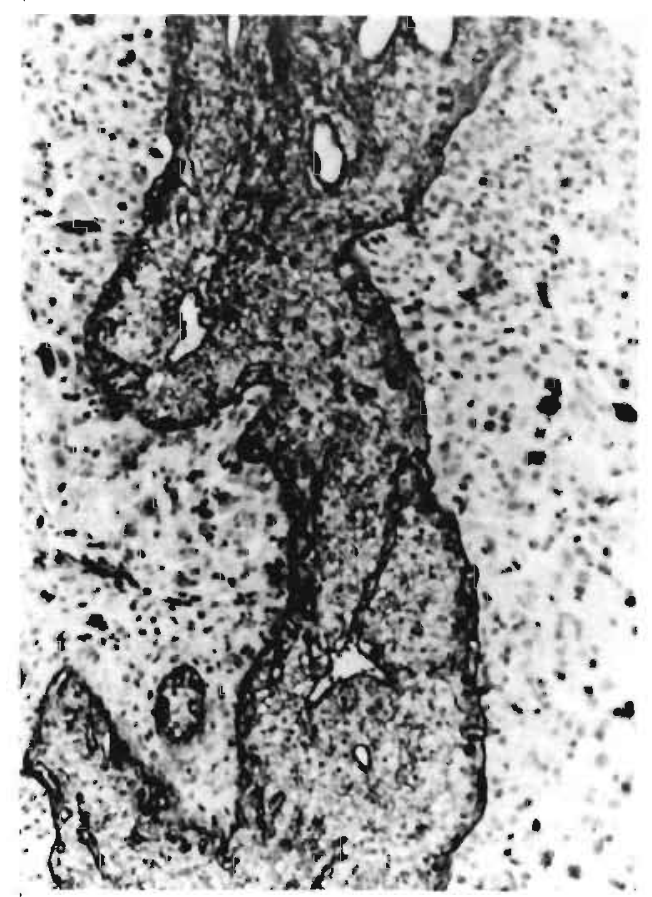

Flgure 2b 


$$
\text { . }
$$




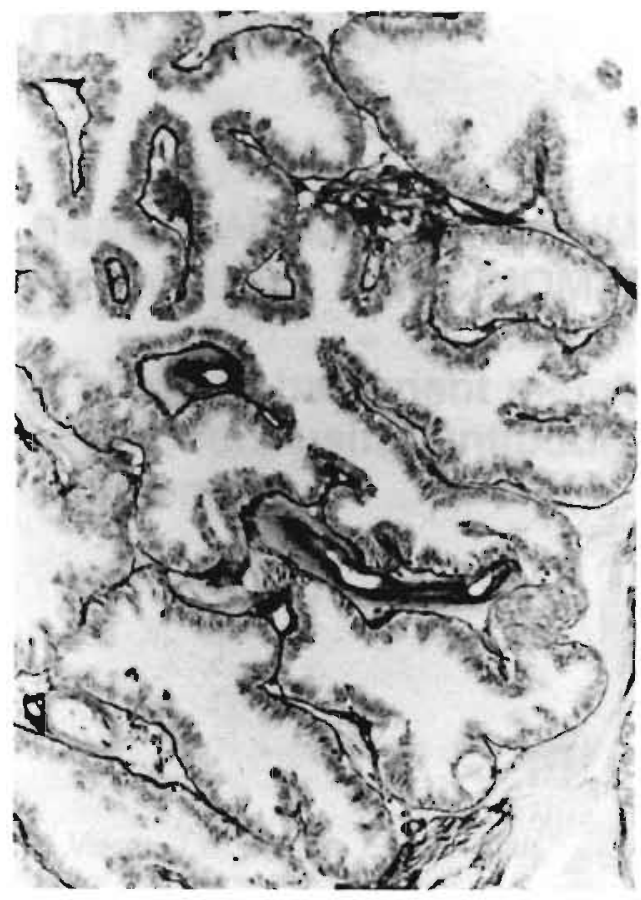

Flgure 4a

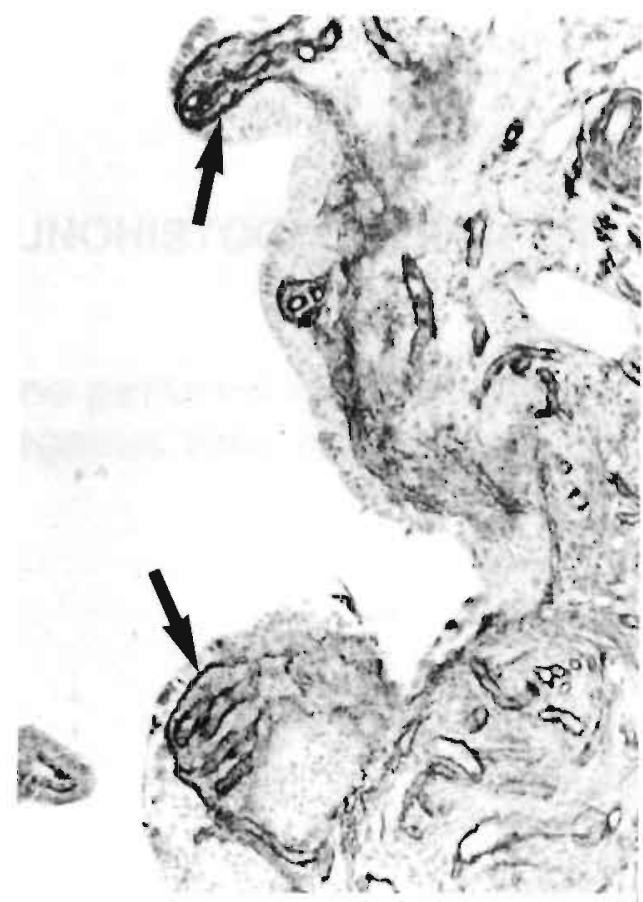

Figure $4 b$ 



\section{CHAPTER 4}

\section{BASEMENT MEMBRANE IMMUNOHISTOCHEMISTRY IN}

RENAL CELL CARCINOMA

A study of basement membrane patterns in small renal cell tumors using antibodies against type IV collagen and laminin.

R. Visser, J.W. Arends, F.T. Bosman

$J$ Urol Pathology 1993 (in press) 
Reral cell carcinomas are tumors of varying histological appearance and clinical behaviour. In many studies various morphologic parameters have been correlated with biological properties of these tumors. Tumor stage appeared to be adversely related with prognosis $(1,2)$ and with regard to nuclear grade it appeared that high grade tumors are generally associated with shorter disease-free interval $(2,3,4)$. Furthermore the tumor type is relevant: papillary and spindle cell tumors show a less favourable prognosis than tumors with a solid pattern (2).

Of small renal cortical adenomas the biological behaviour is still a matter of debate. Based on the low metastatic propensity of tumors measuring less than $3 \mathrm{~cm}$ in diameter, Bell (5) classified these tumors as adenomas. Larger tumors, which more frequently develop subsequent metastasis, were classified as adenocarcinoma. It is generally recognized that histological characteristics can not distinguish between adenoma and adenocarcinoma of the kidney.

Because metastasis is preceded by invasive growth, it is not unlikely that the varying metastatic capacity of small renal cell tumors might be correlated with the presence or absence of invasive growth. Immunohistochemical staining of basement membrane antigens has been advocated as a tool in the study of invasive growth.

Although interruptions in the basement membrane are not always caused by invasively growing neoplastic cells $(6,7,8)$, and, on the other hand, invading cells may be surrounded by basement membranes (9), immunohistochemical visualization of the basement membrane might be indicative of invasive growth and thus might constitute a useful parameter to distinguish between non-invasive (with intact basement membranes) and invasive renal cortical tumors (with interrupted basement membranes). To investigate this possibility we executed an immunohistochemical study with antibodies directed against the basement membrane proteins laminin and type IV collagen.

The significance of basement membrane staining patterns in predicting the behaviour of small renal cortical neoplasms can only be established in case material with follow-up information, which was not at our disposal, partly due to the fact that small renal cortical neoplasms are usually encountered in autopsy specimens and rarely in nephrectomy specimens.

Therefore we compared basement membrane expression patterns with tumor size and with nuclear grade, which both have been shown prognostically valuable.

\subsection{MATERIALS \& METHODS}

\subsubsection{Tissue}

Renal cell tumors ( $n=41$ ), diagnosed as renal cell carcinoma or renal cortical adenoma and with a maximal diameter of $60 \mathrm{~mm}$, were selected from our own files and from those of the dept of Pathology, Erasmus University, Rotterdam (courtesy of dr FWJ ten Kate) and classified into 5 groups, according to the tumor diameter: $\leq 10 \mathrm{~mm}(n=12) ; 11-20 \mathrm{~mm}$ $(n=7), 21-30 \mathrm{~mm}(n=15), 31-40 \mathrm{~mm}(n=4)$, and $>40 \mathrm{~mm}(n=3)$.

Thirty of these tumors were encountered in nephrectomy specimens and were classified as renal cell carcinoma. Eleven tumors (measuring less than $10 \mathrm{~mm}$ in diameter), were obtained at autopsy, which precluded clinico-pathological correlation in these cases.

Tissue blocks were routinely fixed in $4 \%$ buffered formaldehyde and paraffin embedded. For orientation and for diagnostic purposes $3 \mu$ sections were stained with haematoxylin and eosin (H\&E).

Histological classification was performed according to the criteria of the World Health Organization (10) and nuclear grading according to the protocol of Fuhrman (3). 


\subsubsection{Immunohistochemistry}

For immunohistochemical evaluation of every tumor one section from the tumor periphery and one section from the centre of the tumor was selected. These were immunostained for laminin and type IV collagen.

Polyclonal antibodies against mouse type IV collagen and laminin were raised in rabbits and affinity purified as described earlier $(11,12)$. Paraffin sections $(3 \mu)$ of these tumors were deparaffinized and blocked for endogenous peroxidase with $0.6 \%$ hydrogen peroxide in methanol during 15 minutes and washed $3 \times 5$ minutes in demineralized water.

Tissue sections were treated with $0.1 \%$ pepsin (Sigma) in $0.1 \mathrm{~N} \mathrm{HCl}$ at room temperature during 30 minutes to unmask immunoreactivity for the two basement membrane components (13). After rinsing ( $3 \times 5 \mathrm{~min})$ in demineralized water the sections were preincubated with normal swine serum and subsequently exposed to polyclonal anti-type IV collagen (1:250 diluted in Trizma buffered saline (TBS) with $0.1 \% \mathrm{BSA}$ ) or anti-laminin antibodies ( $1: 100$ diluted in TBS with $0.1 \% \mathrm{BSA})$. After washing and incubation with a horseradish peroxidase conjugated swine anti-rabbit antibody (DAKO PATTS) (45 minutes, room temp) the slides were washed again in TBS before a diaminobenzidine reaction was executed. Imidazole was added to the substrate solution in order to enhance the staining intensity. Finally, tissue sections were counterstained with Mayer's haematoxylin for 1 minute. Basement membrane patterns were scored in the centre of the tumor and at the periphery using a semiquantitative scoring scale. When basement membrane interruptions were not observed this was scored as "intact" $(+)$ when interruptions were seen or the basement membrane appeared to be absent, this was classified as "not intact" (-).

\subsubsection{Statistics}

To compare the observed frequencies with the frequencies expected in case of a homogeneous distribution, the Chi-squared test (two-sided), corrected according Yates was used (14).

\section{3}

\section{RESULTS}

\subsubsection{Histological findings}

According to the criteria of the WHO, 29 of the renal tumors were predominantly of the clear cell type, while 11 tumors appeared to be composed of a combination of clear cells and granular cells. One tumor was composed of oncocytic cells. Spindle cell tumors were not present in our series. The tumors showed a variety of glandular patterns with solid, fubular, acinar, papillary and cystic formations, or combinations of these patterns. The tumors were graded according to the criteria of Fuhrman (3). Each tumor was graded by the highest nuclear grade, even when the higher grade occurred only focally. In our series 9 tumors had grade 1, 15 tumors grade 2 and 17 tumors grade 3 . When the tumor grade was compared with tumor size, grade 1 tumors occurred significantly more often in the group of tumors with a diameter of less than $10 \mathrm{~mm}$ than in the larger tumors. However, grades 2 and 3 were found in all tumor sizes (Table 1).

\subsubsection{Immunohistochemical patterns in renal tumors}

For assessment of basement membrane immunoreactivity in the tumors, neighbouring tubules and vascular structures served as a positive control. In general, staining intensity for laminin and type IV collagen was sufficient for scoring purposes, although a few specimens displayed weak laminin immunoreactivity; these were not included in this series. Post mortem specimens showed excellent immunoreactivity. 
Immunoreactivity of basement membrane components at the periphery of the tumor could be determined in 38 cases and in the central parts of the tumor in 36 cases. Tumors measuring less than $10 \mathrm{~mm}$ in diameter significantly more often showed intact central and peripheral basement membranes than larger tumors (Tables 2 and 3, fig. 1 and 2). Two tumors showed focal basement membrane absence in the periphery and 1 showed this phenomenon in the centre of the tumor. A more heterogeneous pattern was found in tumors with a diameter of more than $10 \mathrm{~mm}$. The majority of these tumors displayed limited basement membrane expression in the tumor centre as well as in the periphery (fig. 3 and 4). Only 3 tumors showed intact basement membranes in the periphery (fig. 5) and only 5 tumors showed intact basement membranes in the tumor centre (fig. 6). One tumor did not show any peripheral basement membrane immunoreactivity. All but one of the tumors with a diameter exceeding $30 \mathrm{~mm}$ showed focal absences of the basement membrane both in the tumor centre and periphery and were classified as "not intact". Only one of these larger tumors contained intact basement membranes in the centre.

When the basement membrane patterns of the tumors were compared with the nuclear grade according to the criteria of Fuhrman, a significant correlation was found between nuclear grade and basement membrane patterns in the centre and at the periphery of the tumor (Tables 4 and 5).

\subsection{DISCUSSION}

The most frequent neoplasm of the kidney in adults is renal cell adenocarcinoma. These tumors, which supposedly originate from tubular epithelium $(15,16)$ have attracted attention because of their variable biological behaviour. Tumor behaviour can, to a certain extent, be predicted by the stage of the tumor, the tumor grade and by the histological subtype. For example, the sarcomatoid variant carries a poor prognosis (17).

Bell (5) introduced a classification based on the size of the tumor. Tumors less than 3 centimeters in diameter appeared to metastasize rarely and most, but not all, of the larger tumors subsequently developed metastases. Therefore, it has become customary to classify tumors less than $3 \mathrm{~cm}$ as adenoma and those larger than $3 \mathrm{~cm}$ as carcinoma. This classification has been used widely since then, but has also been criticized. Several authors have discarded this classification and consider all tumors as renal cell carcinoma, but small tumors as "renal adenocarcinoma of low metastatic potential" $(17,18)$. However, other authors have held the view that renal adenomas do exist and can even be distinguished by histological criteria $(19,20)$. This view is supported by Dal Cin and coworkers (21), who found chromosomal aberrations in tumors that were histopathologically diagnosed as cortical adenomas. These aberrations were different from those commonly found in renal cell carcinomas. Small renal cortical neoplasms might therefore consist of two subgroups, adenomas and small adenocarcinomas, that cannot be reliably distinguished on the basis of histological characteristics, immunohistochemistry or ultrastructure $(17,22)$, but with a different biological potential in terms of invasive growth and subsequent metastasis.

The basement membrane plays a crucial role in malignant neoplasia, in particular as a barrier to be taken by invasively growing tumor cells. Therefore, basement membrane immunohistochemistry might help to discriminate between (non invasive) adenoma and (invasive) adenocarcinoma.

Our results on renal cortical neoplasms indicate that tumor size, tumor grade and basement membrane patterns are closely related. Tumors larger than $10 \mathrm{~mm}$ were almost always of higher nuclear grade, whereas smaller tumors were heterogeneous with regard to nuclear grade. This subdivision is supported by the basement membrane immunohistochemistry results. Tumors smaller than $10 \mathrm{~mm}$ mostly showed intact basement membranes, in the tumor centre as well as in the periphery. Larger tumors mostly showed a heterogeneous pattern with defects in the basement membranes of most of the tumors. These data indicate, in agreement with Bell (5), that tumor size may be an important parameter of 
malignant potential, but with a cut-of point of $1 \mathrm{~cm}$ rather than $3 \mathrm{~cm}$. Taking into consideration the data provided by Fuhrman et al (3), who found in stage I tumors a significant difference in metastatic rate between grade 1 tumors and the tumors of grades 2-4, and our finding, that grade I tumors contained intact basement membranes in the centre and the periphery, we propose that all tumors larger than $10 \mathrm{~mm}$ should be considered potentially malignant. It would be preferable to ascertain this contention in additional studies, including follow-up data, but the rarity of tumors smaller than $10 \mathrm{~mm}$ did not allow us to perform such an analysis on our material.

In conclusion, renal cortical tumors smaller than $10 \mathrm{~mm}$ have a somewhat variable nuclear grade, but mostly intact basement membranes. This finding supports the benign nature of these tumors. 


\section{5}

TABLES

Table 1. Tumor size (in $\mathrm{mm}$ ) in relation to tumor grade.

\begin{tabular}{|l|c|c|}
\hline & $\leq 10$ & $>10$ \\
\hline grade 1 & 8 & 1 \\
grade 2-3 & 4 & 28 \\
\hline
\end{tabular}

$\chi^{2}=19.80 ; P<0.01$

Table 2. Tumor size (in $\mathrm{mm}$ ) in relation to the peripheral basement membrane pattern.

\begin{tabular}{|c|c|c|}
\hline & $\leq 10$ & $>10$ \\
\hline+ & 9 & 3 \\
- & 2 & 24 \\
\hline
\end{tabular}

$(+=$ intact basement membrane, $-=$ not intact basement membrane $): \chi^{2}=18.08 ; P<0.01$

Table 3. Tumor size in relation to central basement membrane pattern.

\begin{tabular}{|c|c|c|}
\hline & 510 & $>10$ \\
\hline+ & 9 & 6 \\
- & 1 & 20 \\
\hline
\end{tabular}

$(+=$ intact basement membrane, $-=$ not intact basement membrane $) ; \chi^{2}=13,31 ; P<0.01$

Table 4. Nuclear grade in relation to central basement membrane pattern.

\begin{tabular}{|l|c|c|}
\hline & grade 1 & grade 2 and 3 \\
\hline+ & 7 & 7 \\
- & 1 & 20 \\
\hline
\end{tabular}

$(+=$ intact basement membrane, $-=$ not intact basement membrane $) ; \chi^{2}=18.55 ; P<0.01$

Table 5. Nuclear grade in relation to peripheral basement membrane pattern.

\begin{tabular}{|c|c|c|}
\hline & grade 1 & grade 2 end 3 \\
\hline+ & 7 & 5 \\
- & 1 & 25 \\
\hline
\end{tabular}

$(+=$ intact basement membrane, $-=$ not intact basement membrane $) ; \chi^{2}=8,75 ; P<0.01$ 
1. Robson $\mathrm{CJ}$, Churchill BM, Anderson $W$. The results of radical nephrectomy for renal cell carcinoma. J Urol 1969; 101: 297-301.

2. Medeiros LJ, Gelb AB, Weiss LM. Renal cell carcinoma. Prognostic significance of morphologic parameters in 121 cases. Cancer 1988; 61: 1639-1651.

3. Fuhrman SA, Lasky LC, Limas C. Prognostic significance of morphologic parameters in renal cell carcinoma. Am J Surg Pathol 1982; 6: 655-663.

4. Green LK, Ayala AG, Ro JY, Swanson DA, Grignon DJ, Giacco GG, Guinee VF. Role of nuclear grading in stage I renal cell carcinoma. Urology $1989 ; 34 ; 310-315$.

5. Bell ET. Tumors of the kidney. In Bell ET (ed): Renal diseases (ed 2). Philadelphia, Lea \& Febiger, 1950.

6. Martinez-Hernandez A, Amenta PS. The basement membrane in pathology. Lab Invest 1983; 48; $656-678$.

7. Timpl R. Structure and biological activity of basement membrane proteins. Eur J Biochem 1989; 180: 487502.

8. Visser R, van der Beek JM, Havenith MG, Cleutjens JPM, Bosman FT. Immunocytochemical detection of basement membrane antigens in the histopathological evaluation of laryngeal dysplasia and neoplasia. Histopathology 1986; 10: 171-180.

9. Bosman FT, Havenith MG, Cleutjens JPM. Basement membrane in cancer. Ultrastruct Pathol 1985; 8: 291304.

10. Mostofi FK, Sesterhenn IA, Sobin LH. Histological typing of kidney tumours. In: International histological classification of tumours. No 25 World Health Organization 1981: 17-18.

11. Havenith MG, Cleutjens JPM, Beek C, v.d.Linden E, de Goeij AFPM, Bosman FT. Human specific anti-type IV collagen monoclonal antibodies, characterization and immunohistochemical application. Histochemistry 1987; 87: 123-128.

12. Havenith MG, Dingemans KP. Cleutjens JPM, Wagenaar Sj Sc, Bosman FT. Basement membranes in bronchogenic squamous cell carcinoma: an immunohistochemical and ultrastructural study. Ultrastruct Pathol 1990; 14(1): $51-63$.

13. Barsky SH, Rao NC, Restrepo C, Liotta LA. Immunocytochemical enhancement of basement membrane antigens by pepsin: applications in diagnostic pathology. Am J Clin Pathol 1984; 82(2): 191-94.

14. Kirkwood BR. Essentials of medical statistics. Oxford, Blackwell Scientific Publications, 1988.

15. Störkel S, Jacobi GH. Systematik, Histogenese und Prognose der Nierenzellkarzinome und des renalen Onkozytoms. Verh Disch Ges Pathol 1989; 73: 321-338.

16. Cohen C, McCue PA, Derose PB. Histogenesis of renal cell carcinoma and renal oncocytoma. An immunohistochemical study. Cancer 1988; 62: 1946 1951.

17. Petersen RO. Urologic Pathology. Philadelphia, JB Lippincott, 1986.

18. Bennington JL, Beckwith JB. Tumors of the kidney, renal pelvis and ureter (fascicle 12). In: Atlas of tumor pathology, 2nd series, Washington DC, Armed Forces Institute of Pathology, 1975.

19. Mostofi FK, Sesterhenn IA, Davis Jr CJ. Benign tumors of the kidney. EORTC Genitourinary Group Monograph 5: Progress and controversies in oncological urology II. 1988; 329-344: Alan R. Liss, Inc.

20. Davis Jr CJ. Pathology of renal neoplasms. Seminars in Roentgenology 1987; 22:233-240.

21. Dal Cin P, Gaeta J, Huben R, Li FP, Prout GR, Sandberg AA. Renal cortical tumors. Cytogenetic characterization. Am J Clin Pathol 1989; 92: 408-414.

22. Fisher ER, Morvat B. Comparative ultrastructural study of so called renal adenoma and carcinoma. J. Urol 1972; 108: 382-386. 


\section{LEGENDS TO THE FIGURES}

Figure 1. Small renal cell carcinoma. Intact basement membranes at the periphery of the tumor (arrows) (a: type IV collagen, $\times 125$; b: laminin, $\times 350$ ).

Figure 2. Small renal cell carcinoma. Intact basement membranes in the central part of the tumor (type IV collagen, $\times 350$ ).

Flgure 3. Renal cell carcinoma (diameter $>10 \mathrm{~mm}$ ), central part. Interrupted basement membranes (type IV collagen, $\times 350$ ).

Figure 4. Renal cell carcinoma (diameter $>10 \mathrm{~mm}$ ), periphery. Interrupted basement membranes (laminin, x250).

Figure 5. Renal cell carcinoma (diameter $>10 \mathrm{~mm}$ ), periphery. Intact basement membranes (type IV collagen, $\times 125$ ). Adjacent to the tumor, atrophic tubules and a compressed glomerulus is present.

Figure 6. Renal cell carcinoma (diameter $>10 \mathrm{~mm}$ ), central part. Intact basement membranes (laminin, $\times 125$ ).

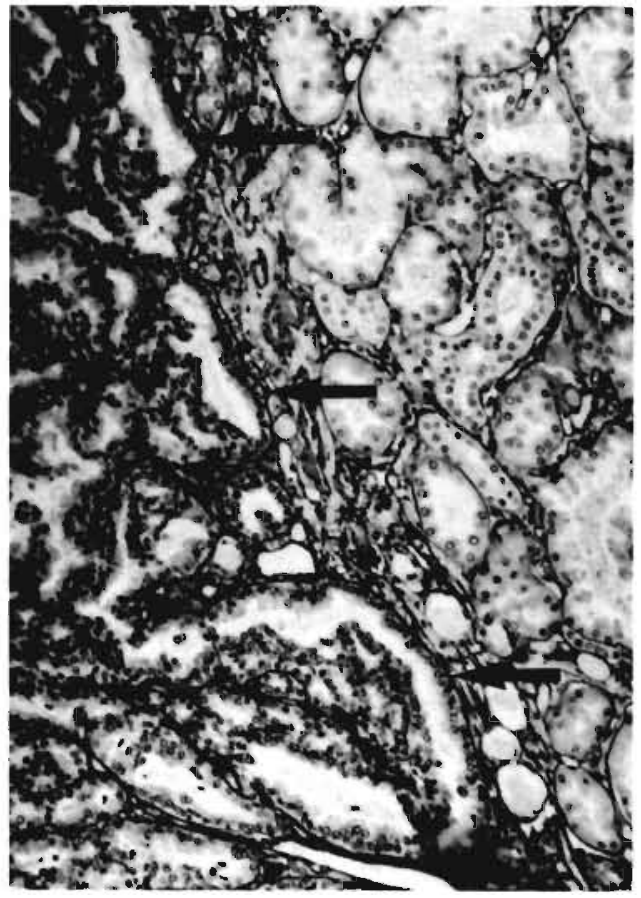

Flgure 1a

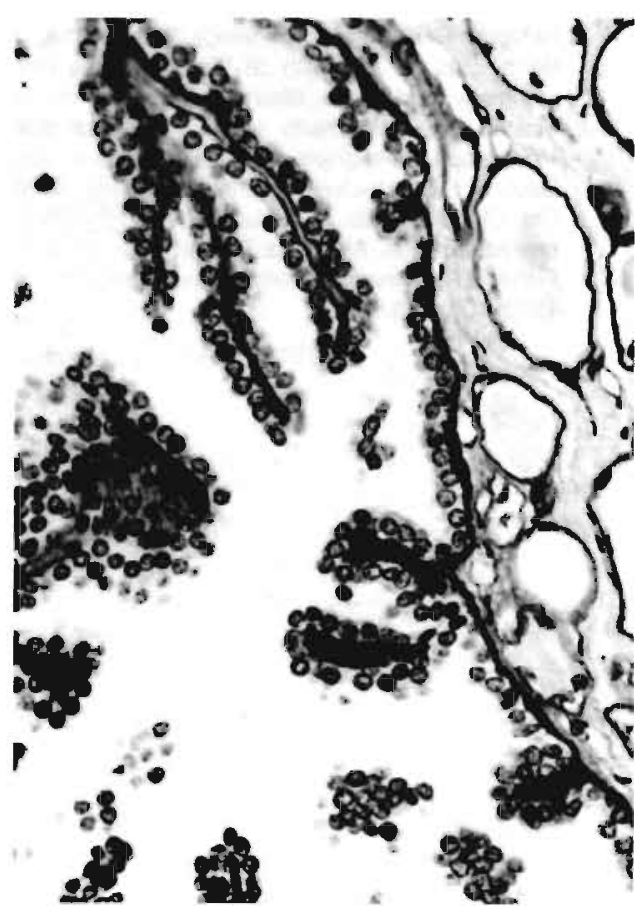

Figure 10 


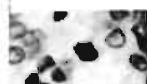
$400 \%$ of ${ }^{2}$

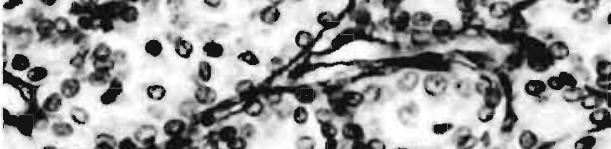


- 5 sor.

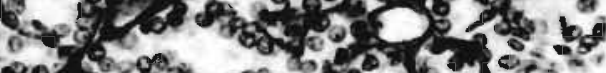

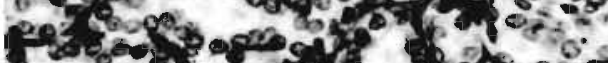
cis

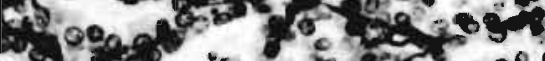
-

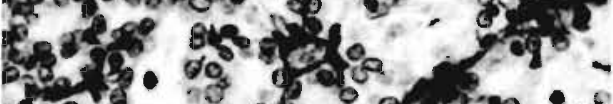
10. 1.

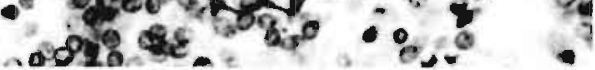

Figure 2

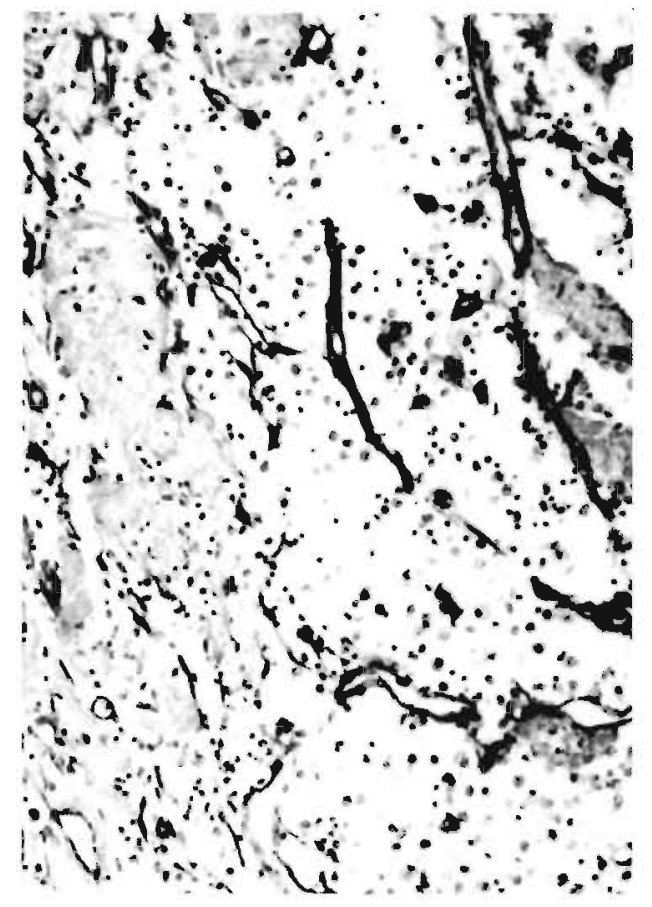

Flgure 4

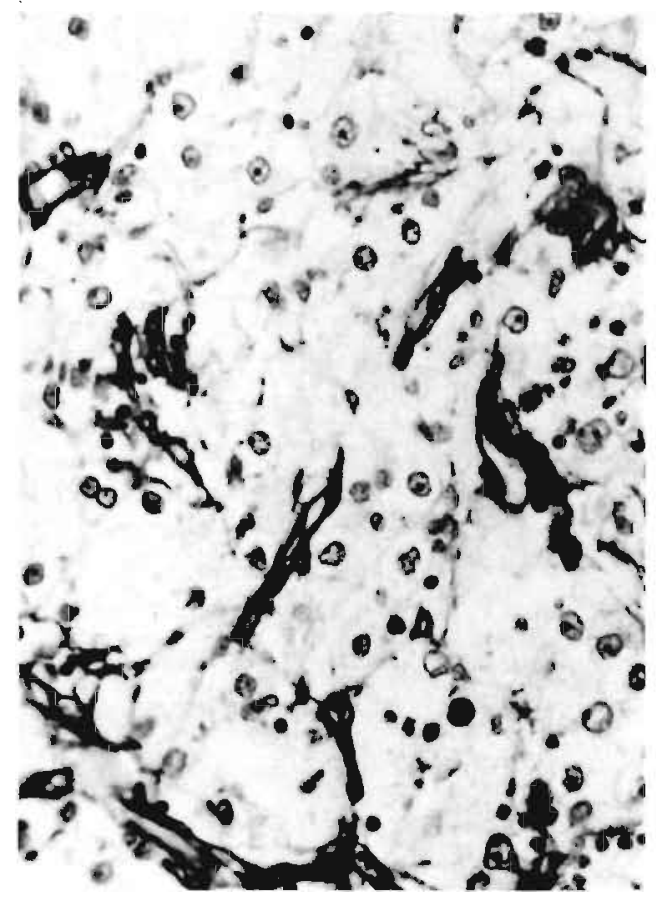

Figure 3 



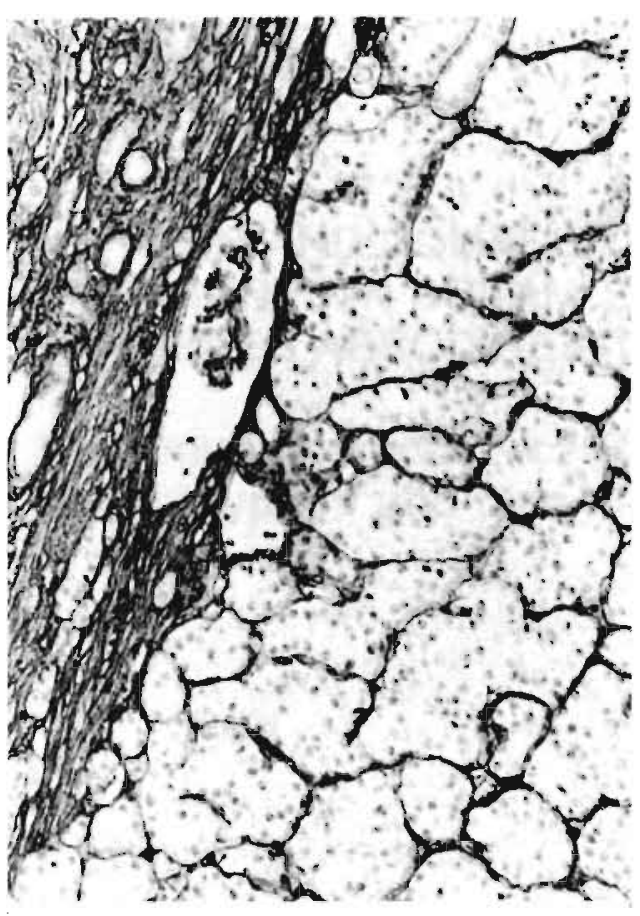

Figure 5

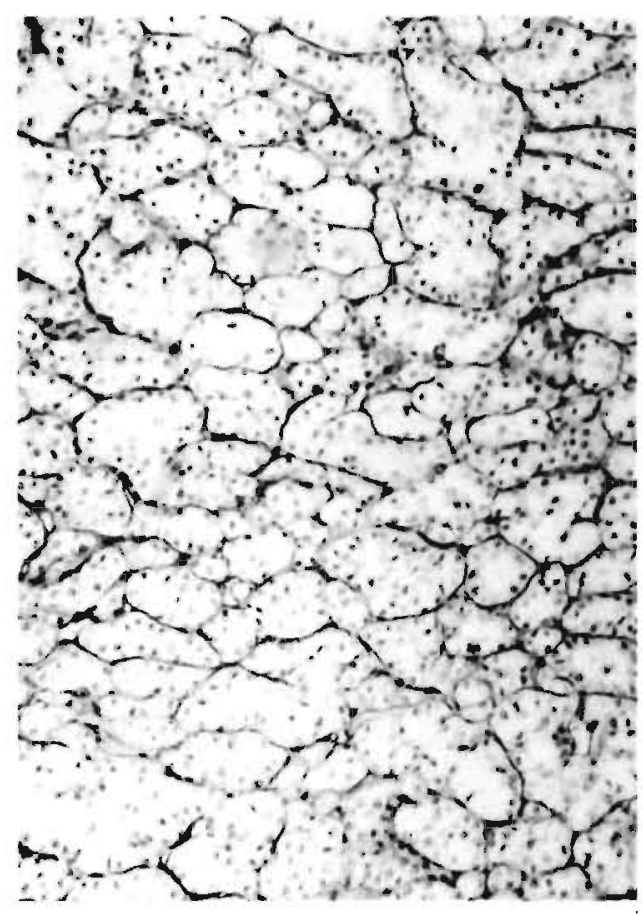

Figure 6 



\section{CHAPTER 5}

\section{PATTERN AND COMPOSITION OF BASEMENT}

MEMBRANES IN SQUAMOUS CELL CARCINOMAS OF THE UPPER AERODIGESTIVE TRACT.

An immunohistochemical study with antibodies directed against type IV and type VII collagen.

R. Visser, JW Arends, FT Bosman

submitted for publication 
The epithelium, lining the mucosa of the mouth and upper respiratory tract is demarcated by a continuous and regular basement membrane composed of type IV collagen and laminin, but also containing type VII collagen, a newer member of the collagen family. Type VII collagen is the principal constituent of the anchoring fibrils, which link the lamina densa of the basement membrane with the adjacent stroma, and shows a somewhat restricted tissue distribution $(1,2)$.

Basement membranes have been studied extensively in recent years in connection with neoplastic growth. In immunohistochemical studies, using antibodies against type IV collagen and laminin, basement membrane discontinuities were observed in in situ as well as in invasive carcinomas (3-6), but interruptions have also been observed in areas with inflammation in close proximity to the surface epithelium (7). Conversely, in well differentiated squamous cell carcinoma, often the basement membrane appeared to be rather regular.

So far, very few studies comparing type IV collagen and type VII collagen distribution patterns in neoplasia have been published (8-11). In the present investigation, therefore, we studied the occurrence of types IV and VII collagen in the basement membrane in the upper aerodigestive tract mucosa and the pattern of basement membrane deposition in squamous cell carcinoma in this region. This was accomplished by immunohistochemistry, using antibodies specific for collagen type IV and monoclonal antibodies specific for type VII collagen. Special attention was paid to possible correlations between deposition pattern and tumor cell differentiation.

MATERIALS \& METHODS

\subsubsection{Tissue}

We collected tissue specimens from 30 consecutive cases of squamous cell carcinoma from different locations in the head and neck region including larynx, pharynx and oral cavity. The tissue specimens encompassed biopsies and samples of resection specimens. From the resection specimens tissue sections were selected which contained carcinoma tissue as well as adjacent apparently normal squamous epithelium. About half of every tissue specimen was frozen in isopentane, quenched in liquid nitrogen, and stored at $-70^{\circ}$ $C$ until use. The other half was fixed in $4 \%$ neutral buffered formaldehyde and embedded in paraffin, according to routine procedures.

\subsubsection{Immunohistochemistry}

\section{Antibodies}

Polyclonal antiserum directed against type IV collagen was raised in rabbits with human placental type IV collagen as immunogen. Characterization and immunospecificity have been described before (13).

A monoclonal antibody against type VII collagen was used in this study: NP-76, which reacts with the amino terminus of the NC-1 domain of the molecule. This antibody was kindly provided by dr R.E. Burgeson (Portland, Oregon, USA).

\section{Type IV collagen}

Paraffin sections $(3 \mu \mathrm{m})$ were deparaffinized and blocked for endogenous peroxidase with $0.6 \%$ hydrogen peroxide in methanol during 15 minutes and washed $3 \times 5$ minutes in demineralized water and afterwards in Trizma buffered saline (TBS). Then, the sections 
were treated with $0.1 \%$ pepsin (Sigma) in $0.1 \mathrm{~N} \mathrm{HCl}$ at room temperature (RT) during 30 minutes to unmask immunoreactivity for type IV collagen (12).

After rinsing $(3 \times 5 \mathrm{~min})$ in demineralized water the sections were exposed to a rabbit antitype IV collagen antiserum (diluted 1:250 in TBS with 1\% BSA and 0.1\% Tween). After washing, the sections were incubated with a horseradish peroxidase conjugated swine antirabbit antibody (DAKO PATTS) (45 min) at RT, washed again in TBS, and a diaminobenzidine $/ \mathrm{H}_{2} \mathrm{O}_{2}$ reaction was executed. Imidazole $(0.1 \mathrm{M})$ was added to the substrate solution in order to enhance the staining intensity. The slides were counterstained with Mayer's haematoxylin during 1 minute.

\section{Type VII collagen}

Frozen sections $(4 \mu)$ were cut, airdried and fixed subsequently in $4 \%$ buffered formalin during 10 minutes. Then the sections were washed with demineralized water and dehydrated in graded alcohols. After blocking endogenous peroxidase with $0.3 \% \mathrm{H}_{2} \mathrm{O}_{2}$ (15 min), sections were again rinsed in demineralized water ( $3 \times 5 \mathrm{~min})$ and briefly in TBS. Then the sections were incubated with the antibody against type VII collagen (diluted 1:500 in TBS with $1 \% \mathrm{BSA}$ and $0.1 \%$ TWEEN), $45 \mathrm{~min}$ at RT. Afterwards the sections were washed ( $3 \times 5$ $\mathrm{min}$ ) and incubated ( $45 \mathrm{~min}, \mathrm{RT}$ ) with horseradish peroxidase conjugated rabbit anti-mouse antibody.

Subsequently the sections were washed again in TBS and treated with diaminobenzidin $/ \mathrm{H}_{2} \mathrm{O}_{2}$. Imidazole was added as described above. The amount of immunoreactivity at the tumor cell-stroma interface was scored semi-quantitatively in terms of presence of immunoreactivity in or around the cell or clusters of cells and in terms of co-expression of the two basement membrane components.

\section{Indirect immunofluorescence doublestaining}

For type IV collagen and type VII collagen doublestaining the sections were first incubated with a mixture of anti-type IV collagen (1:250 diluted) and anti-type VII collagen (1:500 diluted), in TBS $/ 1 \%$ BSA $0,1 \%$ Tween.

As second layer a mixture was used of FITC labeled goat anti- rabbit IgG (Nordic, 1:300 diluted) and rhodamine labeled goat anti- mouse IgG (TAGO Inc, Burlingame, Cal., USA; diluted 1:300).

Specificity of the obtained immune reaction was controlled by identical incubation of parallel sections, but with an irrelevant primary antibody or with TBS instead of the primary antibody.

The fluorescence patterns were photographed with a Leitz dialux fluorescence microscope using alternately FITC and rhodamin filter combinations.

\section{$5.3 \quad$ RESULTS}

The histologically normal epithelium showed intact basement membranes, with a linear type IV collagen immunoreactivity pattern and a similar but somewhat granular pattern of type VII collagen (Fig. 1). A similar pattern was also observed at the interface between the epithelium of the salivary gland ductules and the adjacent stroma. However, type VII collagen was lacking in the basement membrane lining the epithelium of the glandular acini. Unlike type IV collagen, type VII collagen immunoreactivity was not found in the basement membrane around vascular structures, muscle fibres, nerve bundles and adipocytes.

The majority of the squamous cell carcinomas showed moderate differentiation (Table I). In particular the available pharyngeal carcinomas showed a homogeneous, moderate differentiation, while our laryngeal tumors contained areas with poorly and moderately 
differentiated carcinoma. Most oral cavity carcinomas were moderately differentiated but contained focal areas with either poor or high differentiation.

When we compared tumor differentiation with expression of the two basement membrane antigens it appeared that in only one of the five tumors with poor differentiation coexpression of both components occurred. Of tumors with moderate differentiation however a majority (16 of 21 tumors) showed immunoreactivity for the two basement membrane components in an identical pattern (fig 2). In well differentiated carcinomas both components showed identical expression patterns.

As is shown in Table $\|$ we found two patterns of immunoreactivity. All of the poorly differentiated tumors showed type VII collagen staining in the cytoplasm (fig 3); one of these five tumors in addition showed areas with extracellular deposition of type VII collagen (fig 4). This type of staining pattern, both intra- and extracellular, was observed in 9 of the 21 moderately differentiated carcinomas. The other tumors contained either intracellular or extracellular deposition. In the group of well differentiated carcinomas all but one showed only extracellular deposition of type VII collagen.

\section{$5.4 \quad$ DISCUSSION}

The mucosa of the upper aerodigestive tract is lined partly with ciliated columnar, and partly with stratified squamous epithelium. These cells all rest on a basement membrane, which is in direct continuity with the basement membrane of the epithelia of the mucosal glands and their ducts. One of the major constituents of the basement membrane is type IV collagen, which forms, together with laminin, the basic structure of the basement membrane (14-16). A newer member of the collagen family, type VII collagen is a maior unistitutilt ur wie dicnoring tibris $(1,16,1 /)$. These structures, which occur in the pars reticularis of the basement membrane, form a network together with anchoring plaques, which entraps large stromal collagen fibres. As a result the basement membrane is effectively anchored to the underlying stroma (18). The distribution of type VII collagen containing anchoring fibrils is somewhat tissue restricted. Type VII collagen has been found in the skin, chorioamnion, cornea (Bowman's membrane), ectocervix, mucosa of the upper aerodigestive tract and around ducts and lobules of the breast $(1,2,8)$. During the embryonal development of the skin, the occurrence of anchoring fibrils is preceded by the deposition of a basement membrane $(19,20)$.

In invasive carcinoma of the upper aerodigestive tract, but also in some in situ carcinomas, disruption of the basement membrane has been described $(4,5,6)$. In these studies immunohistochemical methods were employed, using antibodies directed against laminin or/and type IV collagen. Basement membrane disruption is not specific for tumor invasion: it occurs also when epithelia are invaded by inflammatory cells (7). Deposition of basement membranes around nests of tumor cells, in co-operation with stromal myofibroblasts has also been reported $(21-24)$.

Studies of type VII collagen deposition in neoplasia as yet are limited to carcinoma of the breast $(8)$, melanoma $(9,10)$ and basal cell carcinoma (11). The distribution patterns of type VII collagen in a variety of malignant tumors were reported by Wetzels et al (2). In the breast it was found that the majority of carcinomas does not contain a basement membrane. However, a minority showed basement membrane staining with a different pattern for type VII collagen, which differed from that of laminin and type IV collagen.

Kirkham et al (10) reported in a study of nevomelanocytic lesions that type IV collagen and type VII collagen line the epidermal basement membrane and this staining pattern is continued around dermal nevus cells. In invasive melanoma gradually gaps were found to occur in the epidermal basement membrane in the invasive front when stained with antibodies against type VII collagen. Type IV collagen often remained detectable in the form of a continuous basement membrane surrounding invading melanoma cells. 
In basal cell carcinomas type VII collagen is deposited around tumor cell nests. This pattern corresponds with that of type IV collagen and laminin (3), although in the desmoplastic or sclerosing type extensive irregularities to sometimes absences of type IV collagen deposition were described (25).

Our findings indicate that in highly differentiated squamous cell carcinoma almost continuous basement membranes occur which contain type IV collagen and type VII collagen. These results are in line with the findings of Wetzels et al (2). With decreasing level of differentiation the tendency of cancer cells to deposit a basement membrane decreases. In this process, loss of deposition of type VII collagen occurs first and is followed by loss of type IV collagen deposition. Strikingly, some poorly differentiated tumor cells retain the possibility to synthesize type VII collagen, but fail to deposit it extracellularly, presumably in relation to the absence of a basal lamina.

These findings suggest, in line with the findings reported by Kirkham et al (10) in melanoma, that type VII collagen might be a more sensitive indicator for invasive growth than type IV collagen because it disappears earlier. Whether or not this might be of diagnostic use will have to be established in clinicopathological studies of early neoplastic lesions. The findings furthermore indicate that type VII collagen synthesis is regulated independent from type IV collagen synthesis, but its extracellular deposition appears to depend on the availability of a type IV collagen matrix. Intracytoplasmic type VII collagen expression might be used as a progression marker for squamous cell carcinoma. The clinical use of this parameter will have to be established in clinicopathological follow-up studies. 


\section{5}

TABLES

TABLE I. Differentiation of 30 carcinomas of the upper aerodigestive tract

\begin{tabular}{|l|c|c|c|c|}
\hline Differentiation & larynx & pharynx & oral cavily & Total \\
\hline poor & - & - & 1 & 1 \\
\hline poor + moderate & 3 & - & 1 & 4 \\
\hline moderate & 3 & 17 & 1 & 21 \\
\hline moderate + well & - & - & 4 & 4 \\
\hline well & - & - & - & 0 \\
\hline Total & 6 & 17 & 7 & 30 \\
\hline
\end{tabular}

TABLE II. Expression pattern of type VII collagen in upper aerodigestive tract squamous cell carcinoma

\begin{tabular}{|l|c|c|c|l|}
\hline dffterentiation & $\boldsymbol{n}$ & $\boldsymbol{c}$ & cle & $\mathbf{e}$ \\
\hline poor & 5 & 4 & 1 & 0 \\
\hline moderate & 21 & 4 & 9 & 8 \\
\hline well & 4 & 1 & 0 & 3 \\
\hline
\end{tabular}

$\mathrm{c}=$ intracytoplasmatic type VII collagen immunoreactivity

$\theta=$ extracellular type VII collagen immunoreactivity

c/e = intra- and extracellular type VII collagen immunoreactivity 
1. Sakai LY, Keene DR, Morris NP, Burgeson RE. Type VIl collagen is a major structural component of anchoring fibrils. J Cell Biol 1986; 103: 1577-1586.

2. Wetzels RHW, Robben HCW, Leigh IM, Schaafsma E, Vooys GP, Ramaekers FCS. Distribution patterns of type VII collagen in normal and malignant human tissues. Am J Pathol 1991; 139; 451-459.

3. Bosman FT, Havenith MG, Visser R, Cleutjens JPM. Basement membranes in neoplasia. Progr Histochem Cytochem 1992; 24 (4): 1-92.

4. Cam $Y$, Caulet $T$, Bellon $G$, Poulin $G$, Legros $M$, Pytlinska $M$. Immunohistochemical localization of macromolecules of the basement membrane and the peritumoral stroma in human laryngeal carcinomas. $J$ Pathol 1984; 144: 35-44.

5. Gusterson BA, Warburton MJ, Mitchell D, Kraft N. Hancock WW. Invading squamous cell carcinoma can retain a basal lamina. An immunohistochemical study using a monoclonal antibody to type IV collagen. Lab Invest 1984; 51:82- 88.

6. Sakr WA, Zarbo RJ, Jacobs JR, Crissman JD. Distribution of basement membrane in squamous cell carcinoma of the head and neck. Hum Pathol 1987; 18: 1043- 1050.

7. Visser $R$, van der Beek JMH, Havenith MG, Cleutjens JPM, Bosman FT. Im munocytochemical detection of basement membrane antigens in the histopatho logical evaluation of laryngeal dysplasia and neoplasia. Histopathology 1986; 10: 171-180.

8. Wetzels RHW, Holland R, van Haelst UJGM, Lane EB, Leigh IM, Ramaekers FCS. Detection of basement membrane components and basalcell keratin 14 in non- invasive and invasive carcinoma of the breast. Am $\mathrm{J}$ Pathol 1989; 134: 571- 579.

9. Schmoeckel C, Stolz W. Sakai LY, Burgeson RE, Timpl R, Krieg T. Structure of basement membranes in malignant melanomas and nevocytic nevi. J Invest Dermatol 1989; 92: 663-668.

10. Kirkham N, Price ML, Gibson B, Leigh IM, Coburn P, Darley CR. Type VII collagen antibody LH 7.2 identifies basement membrane characteristics of thin malignant melanomas. J Pathol 1989; 157: 243-247.

11. Jones JCR, Steinman HK, Goldsmith BA. Hemidesmosomes, collagen VII and intermediate filaments in basal cell carcinoma. J Invest Dermatol 1989; 93: 662-671.

12. Barsky SH, Rao NC, Restrepo C, Liotta LA. Immunocytochemical enhancement of basement membrane antigens by pepsin: applications in diagnostic pathology. Am J Clin Pathol 1984; 82(2): 191-94.

13. Havenith MG, Cleutjens JPM, Beek C, v.d.Linden E, de Goeil AFPM, Bosman FT. Human specific anti-type IV collagen monoclonal antibodies, characterization and immunohistochemical application. Histochemistry 1987; 87: 123-28.

14. Timp/ R. Structure and biological activity of basement membrane proteins. Eur J Biochem 1989; 180: 487502.

15. Martinez-Hernandez A, Amenta PS. The basement membrane in pathology. Lab Invest 1983; 48: 656-678.

16. Leblond CP. Inoue S. Structure, composition and assembly of basement membrane. Am J Anat 1989; 185: 367-390.

17. Burgeson RE. The junction zone and the dermis. The collagens of skin. Curr Probl Derm 1987; $17: 61$.

18. Keene DR, Sakai LY, Lunstrum GP, Morris NP, Burgeson RE. Type VII collagen forms an extended network of anchoring fibrils. J Cell Biol 1987; 104:611-622

19. Tisdale AS, Spurr-Michaud SJ, Rodriguez M, Hackett J, Ktachmer J, Gipson IK. Development of the anchoring structures in the epithelium in rabbit and human fetal corneas. Invest Ophthalmol Vis Sci 1988; 29: 727-736,

20. Smith LT, Sakai LY, Burgeson RE, Holbrook KA. Ontogeny of structural components at the dermalepidermal junction in human embryonic and fetal skin: the appearance of anchoring fibrils and type VII collagen. J Invest Dermatol 1988; 90: 480-485.

21. Gould VE, Battifiora $H$. Origin and significance of the basal lamina and some interstitial fibrillar components in epithelial neoplasms. Pathol Annual 1976; 11: 353-386.

22. Bosman FT, Havenith MG, Cleutjens JPM. Basement membranes in cancer. Ultrastruct Pathol 1985; 8: 291. 304.

23. Damjanov I, Damjanov N, Knowless BB, Engvall D. Origin of laminin in the extracellular matrix of human tumor xenografts in nude mice. Virchows Arch (B) 1985; 49: 45-52.

24. Cleutjens JPM, Havenith MG, Beek C, Vallinga M, ten Kate J, Bosman FT. Origin of basement membrane type IV colfagen in xenografted human epithelial tumor cell lines. Am J Path 1990; 136: 1165-1173.

25. Kallioinen M, Autio Harmainen H, Dammert K, Risteli J, Risteli L. Discontinuity of the basement membrane in fibrosing basocellular carcinomas and basosquamous carcinomas of the skin, an immunohistochemical study. I Invest Dermatol 1984; 82: 248-251. 


\section{LEGENDS TO THE FIGURES}

Flgure 1. Regular basement membranes lining the surface epithelium. Type IV collagen (a), type VII collagen (b); no immunoreactivity between antibodies to type VII collagen and capillary basement membranes (b). $250 \mathrm{x}$, immunofluorescence (doublestaining)

Flgure 2. Squamous cell carcinoma, moderately differentiated. Consecutive sections. Islands of tumor cells surrounded by focally interrupted basement membranes (arrow), with identical patterns of type IV collagen (a) and type VII collagen (b). Antobodies to type VII collagen do not react with vascular basement membranes. 250x, immunoperoxidase.

Flgure 3. Squamous cell carcinoma, poorly differentiated. Consecutive sections. Only capillary basement membranes in type IV collagen staining (a). Only expression of type VII collagen in the cytoplasm of tumor cells (b). $250 x$ (inset, $400 x$ ), immunoperoxidase.

Figure 4. Squamous cell carcinoma, poorly differentiated. Intracytoplasmic and extracellular deposition of type VII collagen. 300x, immunoperoxidase.

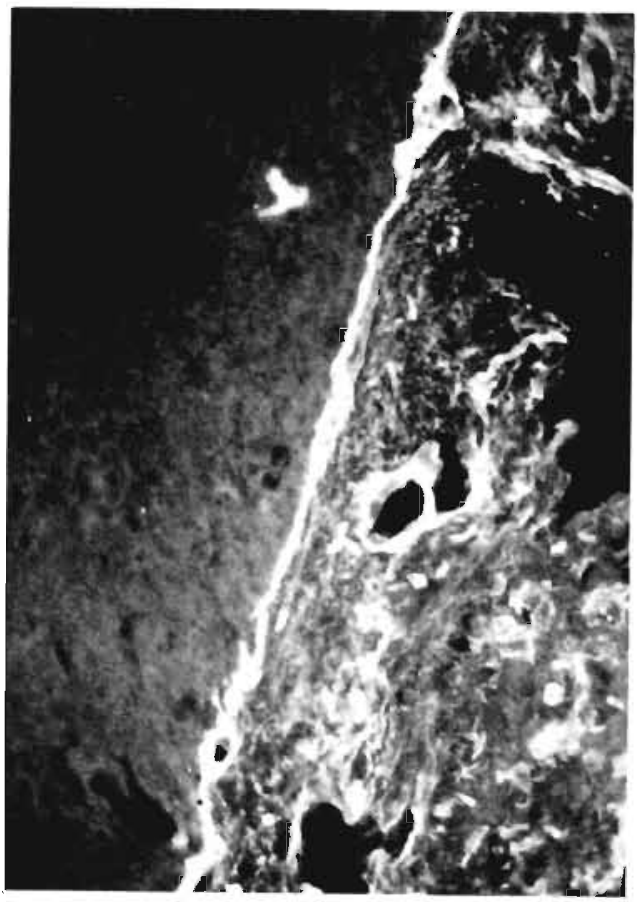

Figure 1a

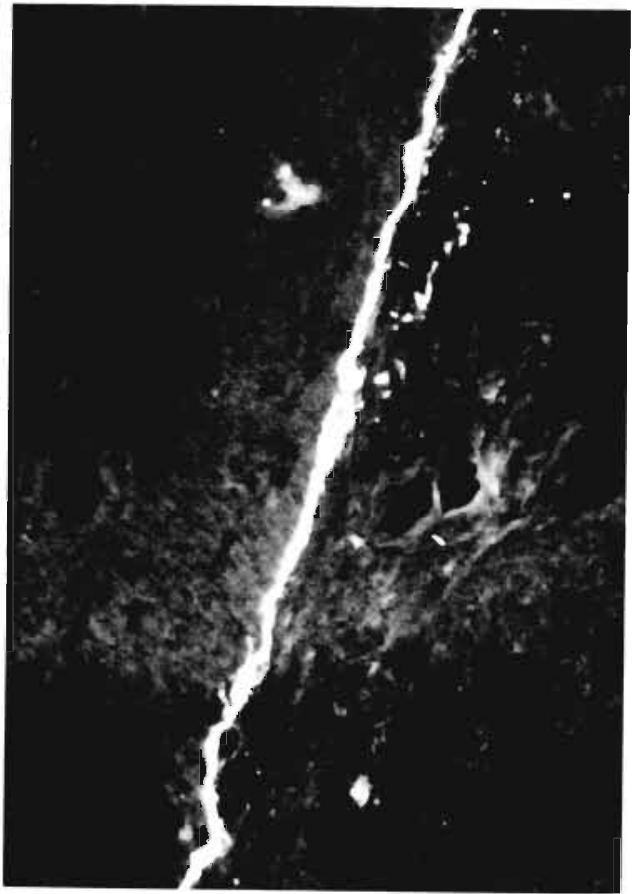

Figure 1b 


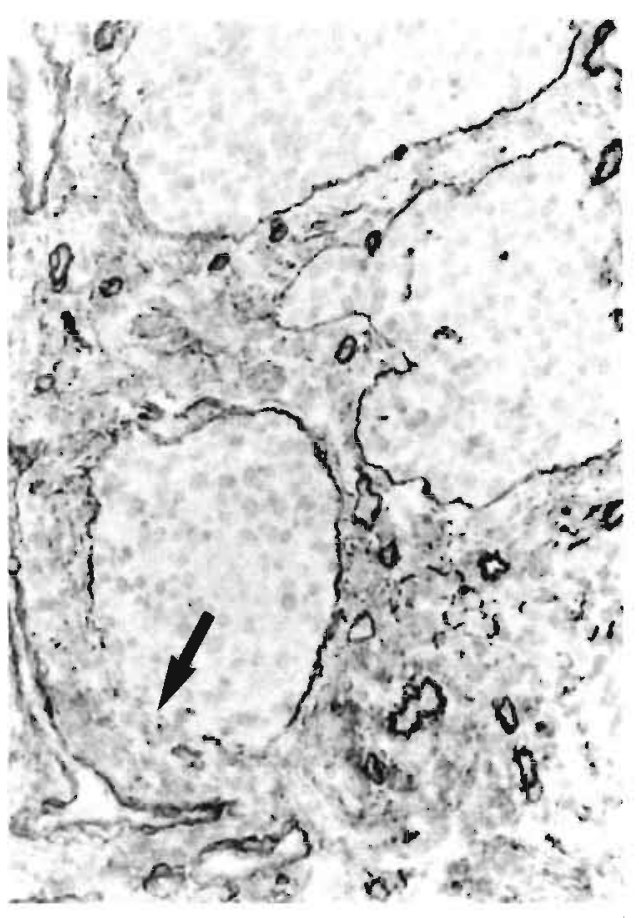

Figure 2a

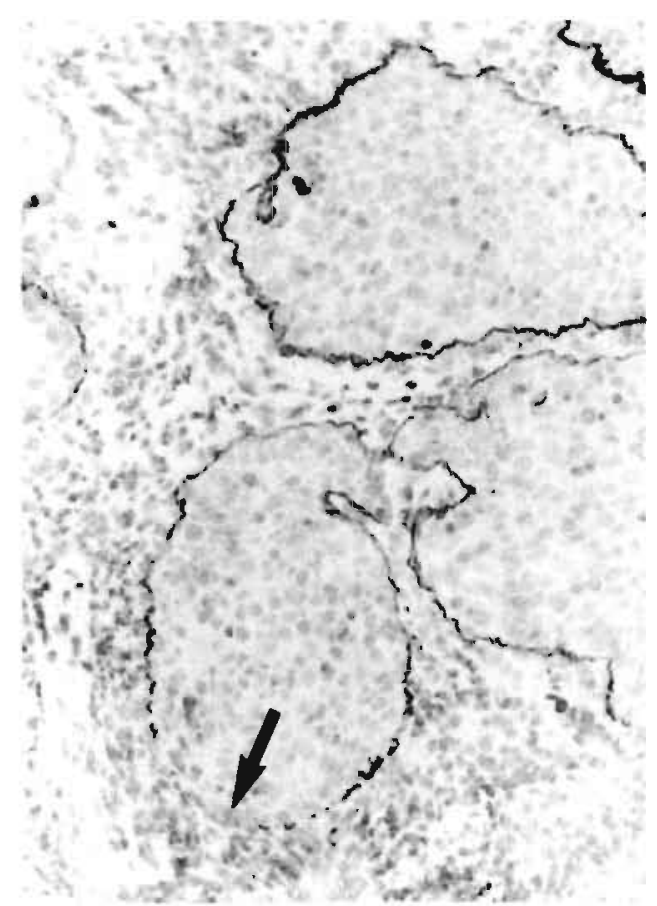

Figure 2b

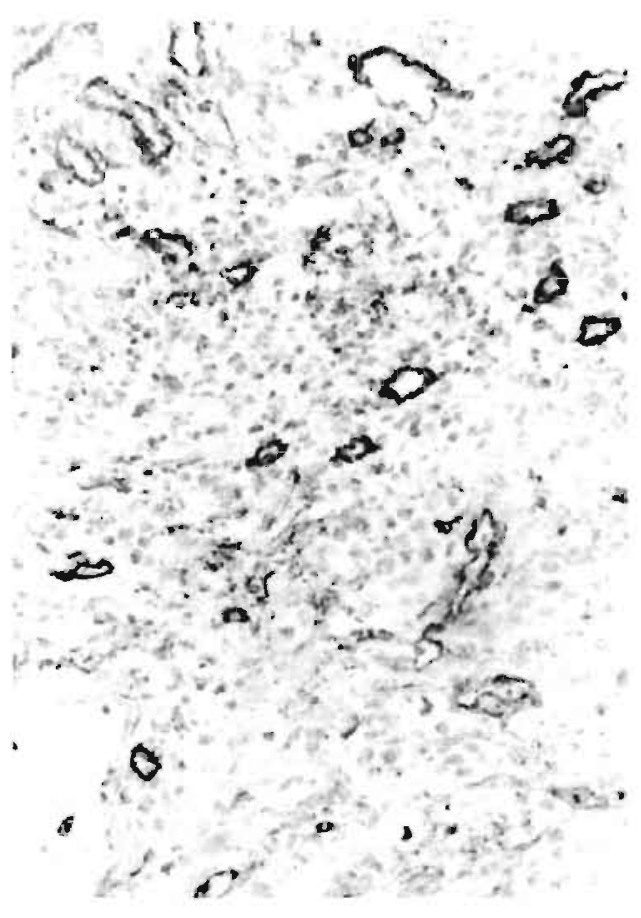

Figure 3a

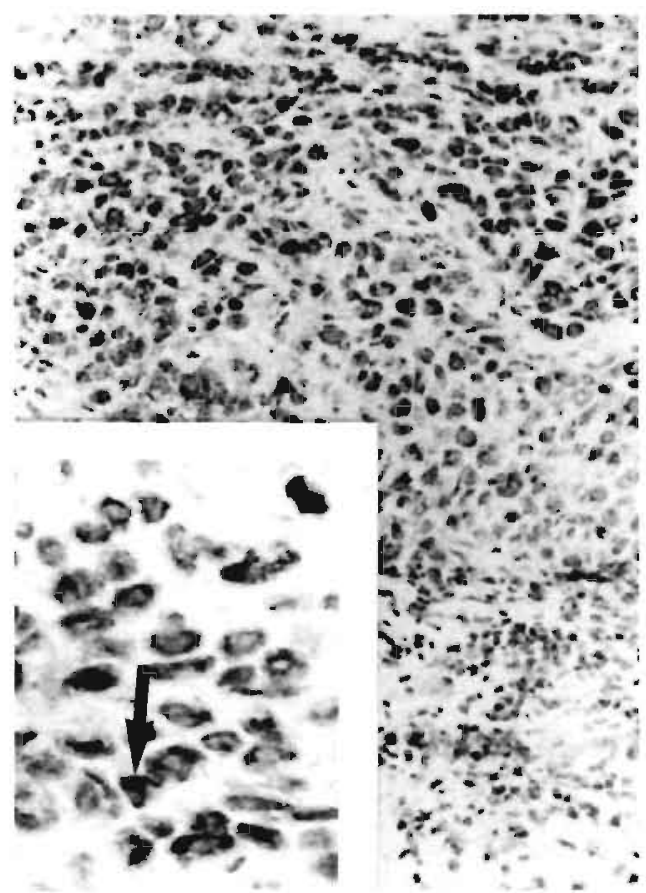

Flgure 3b 



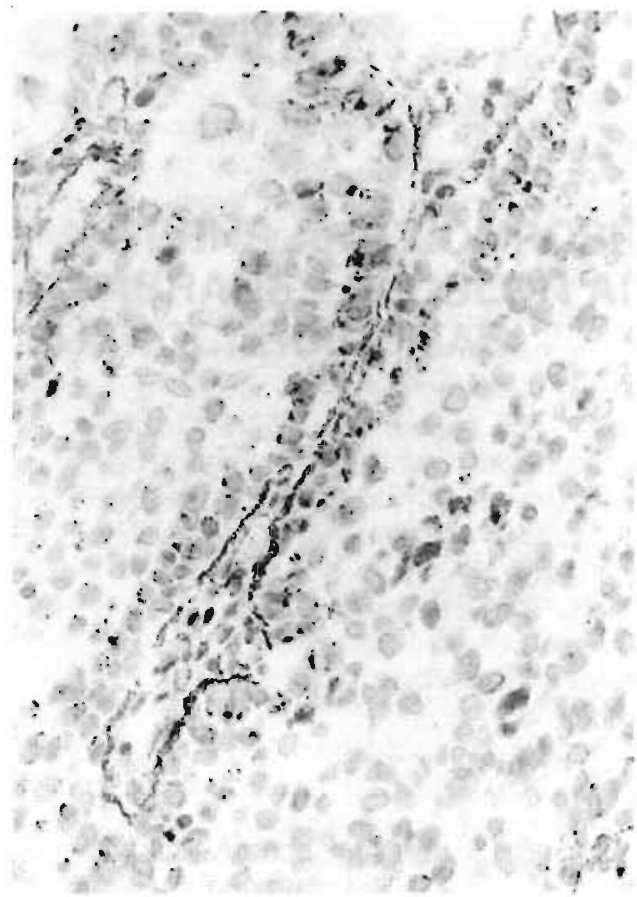

Figure 4 



\section{CHAPTER 6}

PATTERNS AND COMPOSITION OF BASEMENT MEMBRANES IN COLON ADENOMAS AND ADENOCARCINOMAS.

A Visser, JW Arends, IM Leigh, FT Bosman

$J$ Pathol 1993 (in press) 
Invasive growth is a decisive hallmark of malignancy in epithelial cancers. It is a complex multistep process with as initial event the dissolution of the extracellular matrix, including the basement membrane.

In developing neoplastic epithelial lesions progressing towards invasion, a complex and dynamic interaction occurs between epithelial tumor cells and extracellular matrix prior to breakdown of the basement membrane, as seen by morphological methods $(1-4)$. Down regulation of the expression and cell-surface redistribution of integrins and degradation of basement membrane components by proteolytic enzymes such as type IV collagenase, cathepsins, plasminogen activators and plasmin, elastases and heparinases (5) occur. As a result a passage is created for tumour cell migration into the surrounding stroma. The site of basement membrane degradation can be visualized by immunohistochemical staining for basement membrane antigens. Discontinuities are usually evident in carcinomas $(1,6)$, although interruptions have also been reported in inflammatory conditions (7). Basement membranes are, however, also deposited in growing neoplasms and in fact in most neoplasms the observed basement membrane patterns reflect the balance between basement membrane degradation and basement membrane deposition.

In the last decade, many immunohistochemical studies have been performed documenting basement membrane patterns in invasive malignant neoplasia $(8,9)$. In a majority of these studies, antibodies were used against laminin and type IV collagen, two omnipresent components of the basement membrane. These studies have reported that, although the basement membrane structure may be focally or extensively interrupted, the co-expression of type IV collagen and laminin, which is characteristic of a normal basement membrane, is generally maintained.

The situation appears to be different when immunoreactivity for types IV and VII collagen are compared. Type VII collagen is a recently characterized member of the collagen family $(10,11)$. It is related with anchoring fibrils and occurs in connection with a limited number of epithelia: epidermis, chorioamnion, cornea, oral and cervical mucosa. It has recently been reported that in carcinomas of the breast, naevocytic naevi and malignant melanomas, type IV and type VII collagen do not occur in identical patterns, which is indicative of major alterations in the composition of the basement membrane, as a result of invasive growth $(12,13)$.

To further explore a possible role for type VII collagen in the development of invasion in colon cancer we carried out an immunohistochemical study in a series of adenomas and adenocarcinomas of the colon.

The aims of this study were to determine whether or not type VII collagen occurs in the basement membrane of normal and neoplastic colon mucosa, and if so, how it is distributed and furthermore, whether or not type IV collagen and type VII collagen would be similarly distributed in adenomas and carcinomas of the colon.

\subsection{MATERIALS \& METHODS}

\subsubsection{Tissue}

The tissues used for this study comprised of three groups. The first group contained normal mucosa samples from the descending colon and rectum from 4 patients under observation for rectal blood loss, but with normal mucosa by coloscopy. The second group contained 28 samples (resection specimens and biopsies) of hyperplastic polyps and adenomas.

The third group consisted of 22 surgically resected colorectal adenocarcinomas.

From each specimen tissue samples were selected and fixed in $4 \%$ neutral buffered formaldehyde and embedded in paraffin according to routine procedures. Sections $(4 \mu \mathrm{m})$ were stained with haematoxylin and eosin and subjected to immunoperoxidase staining 
with antibodies directed against type IV collagen and type VII collagen. In addition, samples were frozen in isopentane, quenched in liquid nitrogen, and stored at $-70^{\circ} \mathrm{C}$. Cryostat sections were cut at $4 \mu \mathrm{m}$, air dried at room temperature and stored at $-20^{\circ} \mathrm{C}$ for immunofluorescence double staining with antibodies directed against type IV collagen and type VII collagen.

\subsubsection{Antibodies}

Antibodies against type IV collagen were raised in rabbits with human placental type IV collagen. Characteristics of the obtained antibodies have been described before (14).

Two monoclonal antibodies against type VII collagen were used in this study: NP-76, which reacts with the amino terminus of the NC-1 domain of the molecule, and LH 7.2 (15).

The antibodies were kindly provided by Drs R.E. Burgeson (Portland, Oregon, USA; NP-76) and I.M. Leigh (London, G.B.; LH 7.2).

Two monoclonal antibodies against cytokeratins were used: RCK 102 directed against keratins 5 and 8 and NCL 5D3 against keratins 8,18 and 19. Both antibodies were obtained from Organon (Oss, The Netherlands).

\subsubsection{Immunohistochemistry}

For indirect immunoperoxidase staining cryostat sections (fixed in $2.5 \%$ buffered formaldehyde for $10 \mathrm{~min}$ ) or rehydrated paraffin sections were immersed in $0.6 \%$ hydrogen peroxide in methanol (15 min) to block endogenous peroxidase. Incubation with the appropriate antiserum was performed for 45 minutes at room temperature (anti type IV collagen diluted 1:250, NP-76 1:500 and LH 7,2 1:10 in Trizma buffered saline (TBS) with 1\%BSA and $0,1 \%$ Tween). After washing in TBS a peroxidase-labelled swine-anti-rabbit conjugate for the polyclonal antibody (diluted 1:500 in TBS/BSA/Tween) and peroxidase-labelled rabbitanti-mouse for the monoclonal antibody (diluted 1:200 in TBS/BSA/Tween) were used (Dakopatts, Denmark). Peroxidase activity was visualized in a substrate solution containing diaminobenzidine (DAB). Imidazole $(0.1 \mathrm{M}$ in Triss $/ \mathrm{HCl})$ was added to enhance the staining intensity. The sections were counterstained with Mayer's haematoxylin.

For indirect immunofluorescence double staining of types IV and VII collagen the same procedure was followed but tissue sections were incubated with a mixture of anti-type IV collagen and anti-type VII collagen, in TBS/1\%BSAV0,1\% Tween.

As second layer a mixture of FITC labelled goat anti rabbit IgG (Nordic, diluted 1:300) and rhodamine labelled goat anti mouse IgG, (TAGO Inc, Burlingame, Ca, USA; diluted 1:300) was used. The fluorescence patterns were photographed with a Leitz Dialux fluorescence microscope using FITC and rhodamine filter combinations alternately.

\section{Histological evaluation}

In adenomas, dysplasia was classified as mild, moderate or severe, according to the highest grade of dysplasia, even when the higher grade occurred only focally. Four adenomas contained foci of adenocarcinoma with superficial invasion. Adenocarcinomas were graded according to their level of differentiation as poorly, moderately and well differentiated, taking the area of lowest differentiation as criterion.

\subsection{RESULTS}

Immunostaining for type IV collagen by immunoperoxidase and immunofluorescence showed consistent immunoreactivity; vascular basement membranes were taken as an internal positive control. Normal epithelia in all specimens displayed a continuous basement membrane. 
By immunoperoxidase staining type VII collagen reactivity was not very intense, but by immunofluorescence a more intense reactivity was observed. The patterns of immunoreactivity for both monoclonal antibodies (NP-76 and LH 7.2) were identical.

\subsubsection{Normal mucosa}

In the specimens containing normal mucosa, continuous basement membranes were observed adjacent to the surface and crypt epithelium when stained for type IV collagen. When stained for type VII collagen, however, no immunoreactivity was seen, neither in vascular nor in epithelial basement membranes.

\subsubsection{Adenomas}

All adenomas showed a normal and structurally intact basement membrane by type IV collagen immunohistochemistry, regardless of the histological type or grade of the adenoma. Type VII collagen immunoreactivity occurred extensively in adenomas and was restricted to the basement membrane zone (Fig 1). Although type IV collagen was homogeneously distributed with a linear pattern at the interface between epithelium and stroma, type VII collagen immunoreactivity was more intense in the basement membrane of epithelia at the luminal surface of the adenomas and displaying a granular pattern (Fig 2). In the four adenomas with focal adenocarcinoma the latter showed distinctly less intense type VII collagen immunoreactivity. The normal epithelium adjacent to an adenoma occasionally showed type VII collagen reactivity, especially at the luminal surface (Fig 3).

\subsubsection{Adenocarcinomas}

The majority of the adenocarcinomas showed moderate differentiation. The basement membrane staining patterns for type IV collagen in all carcinomas were remarkably similar. The majority of the neoplastic tubules was surrounded by a fairly regular basement membrane, whereas scattered tubules, especially at areas where stroma was scanty, lacked type IV collagen immunoreactivity entirely or showed a discontinuous staining pattern (Fig.4). Dysplastic or normal crypt epithelium, adjacent to the carcinoma, showed a regular basement membrane.

Type VII collagen was found only in well or moderately differentiated adenocarcinomas. Only a few tubules showed basement membranes with type VII collagen immunoreactivity. In poorly differentiated adenocarcinomas no type VII collagen immunoreactivity occurred.

In some tumors the mucosal epithelium adjacent to the tumor showed slight to moderate dysplasia. In these areas types IV and VII collagen appeared to be co-distributed as a continuous basement membrane. Type VII collagen immunoreactivity was consistently more intensive in the superficial parts of these crypts, than in the deeper parts.

Of all specimens containing areas with type VII collagen immunoreactivity, parallel sections were stained for cytokeratins. The pattern of immunoreactivity for both cytokeratin antibodies did not differ between type VII collagen positive and type VII collagen negative specimens.

\section{4}

\section{DISCUSSION}

In this study basement membrane patterns were investigated in normal mucosa of the colon and in colon adenomas and adenocarcinomas, using antibodies directed against type IV collagen and type VII collagen. Type VII collagen is a $320 \mathrm{kD}$ molecule consisting of a triple helical domain of $170 \mathrm{kD}$ and a $150 \mathrm{kD}$ non-helical domain at the carboxy-terminus $(16,17)$. Both basal keratinocytes and a small population of fibroblastic cells synthesize type VII procollagen in the developing skin (10). Type VII collagen, anchoring fibrils and 
hemidesmosomes appear simultaneously at an estimated gestational age of 7-8 weeks, which is 2 weeks later than the basement membrane components type IV collagen and laminin $(18,19)$. Type VII collagen is the major constituent of the anchoring fibrils, which anchor the basement membrane to the adjacent collagenous stroma. Together with hemidesmosomes and anchoring filaments, which attach epithelial cells to the basement membrane, anchoring fibrils mediate attachment of epithelial cells to the stroma. Type VII collagen has been found in the basement membrane zone of the amnion and the basement membrane of stratified epithelia such as oesophageal, oral and cervical mucosa, corneal epithelium, urothelium of the urinary bladder and around ducts of the breast $(11,12)$.

In a small number of studies type VII collagen has been localized in neoplastic tissues. The most notable findings were reported by Kirkham et al $(20)$ in thin cutaneous melanomas. In benign naevi type VII collagen co-localized with type IV collagen and laminin in basement membrane structures surrounding nests of naevus cells. In thin malignant melanoma the tumor cell nests were usually outlined by a basement membrane which also contained type IV collagen and laminin as well as type VII collagen. In malignant melanomas thicker than $0.9 \mathrm{~mm}$, type VII collagen was very irregularly distributed, in spite of almost continuous staining for type IV collagen and laminin. The authors suggest on the basis of these findings that type VII collagen is a better marker for invasive growth in nevomelanocytic lesions than type IV collagen and that the better prognosis of thin melanomas is reflected in integrity of the basement membrane as judged by type VII collagen staining. These findings are in keeping with those reported by Schmoeckel et al (13), who found that around malignant melanomas the basement membranes do contain type IV collagen and laminin, but not type VII collagen.

Against this background we investigated the expression of type IV and type VII collagen in colon mucosa and in colonic neoplasms. We could confirm earlier results reported by Sakai et al (11) that in the normal colon type VII collagen does not occur in the basement membrane. In transitional and dysplastic colonic epithelium a striking pattern of type VII collagen deposition was noted. In mucosa adjacent to adenomas and carcinomas and in adenomatous epithelium, type VII collagen expression appeared in the epithelia close to the luminal surface. What causes the expression of type VII collagen remains unknown. Considering the mechanical functions of type VII collagen it could be hypothesized that increased shear forces on the epithelial surface might induce its expression.

In any case, our findings indicate that the interaction between epithelium and stroma in an adenoma is different from that in the normal mucosa. Whether or not the presence of type VII collagen in adenomas reflects the presence of structurally identifiable anchoring fibrils remains to be further investigated.

Type VII collagen deposition was not related to altered epithelial differentiation as the pattern of cytokeratin expression did not differ between type VII collagen positive and type VII collagen negative epithelia. Also in some carcinomas type VII collagen expression was found, but only in well differentiated carcinomas; in moderately well and poorly differentiated carcinomas this no longer occurred. Furthermore, the extent of type VII collagen deposition was distinctly less in carcinomas than in adenomas. It appears, therefore, that early in the development of colonic neoplasia (e.g. in adenomas) type VII collagen is expressed, whereas in progressed lesions this phenomenon no longer occurs. 
1. Liotta LA, Rao CN, Barsky SH. Tumor invasion and the extra cellular matrix. Lab Invest 1983; 49: 636-650.

2. Liotta LA, Wewer U, Rao NC, Schiffmann E, Stracke M, Guirguis R, Thorgeirsson U, Muschel R, Sobel M. Biochemical mechanisms of tumor invasion and metastases. Adv Exp Med Biol 1988; 233: 161-169.

3. Gorstein F. The dynamic extracellular matrix. Editorial. Hum Pathol 1988; 19: 751- 753.

4. Pauli BU, Knudson $W$. Tumor invasion: a consequence of destructive and compositional matrix alterations Human Pathol 1988; 19: 628-640.

5. Liotta LA. Gene products which play a role in cancer invasion and metastasis. Breast Cancer Res Treat 1988; 11: 113-124.

6. Bosman FT, Havenith MG, Clestjens JPM. Basement membranes in cancer. Ultrastruct Pathol 1985; 8: 291 304.

7. Visser R, van der Beek JMH, Havenith MG, Cleutjens JPM, Bosman FT. Im munocytochemical detection of basement membrane antigens in the histopathological evaluation of laryngeal dysplasia and neoplasia. Histopathology 1986; 10:171-180.

8. Caselitz J. Basal membrane antigens as tumour markers. Curr Top Pathol 1987; 77: 223-243.

9. d'Ardenne A.J. The use of basement membrane markers in tumour diagnosis. J Clin Pathol 1989; $42: 449$. 457.

10. Burgeson RE, Lunstrum GP, Rokosova B, Rimberg CS, Rosenbaum LM, Keene DR. The structure and function of type VII collagen. Ann N-Y-Acad Sci 1990; 580: 32-43.

11. Sakai LY, Keene DR, Morris NP, Burgeson RE. Type VII collagen is a major structural component of anchoring fibrils. J Cell Biol 1986; 103: 1577-1587.

12. Wetzels RHW, Holland $R$, van Haelst UJGM, Lane EB, Leigh IM, Ramaekers FCS. Detection of basement membrane components and basal cell keratin 14 in noninvasive and invasive carcinoma of the breast. Am J Pathol 1989; 134: 571- 580 .

13. Schmoeckel C, Stolz W, Sakai LY, Burgeson RE, Timpl R, Krieg T. Structure of basement membranes in malignant melanoma and nevocytic nevi. J Invest Dermatol 1989; 92: 663-669.

14. Havenith MG, Cleutjens JPM, Beek C, v.d.Linden E, de Goey AFPM, Bosman FT. Human specific anti-type IV collagen monoclonal antibodies, characterization and immunohistochemical application. Histochemistry 1987; 87: 123-128.

15. Leigh IM, Purkis PE, Bruckner-Tuderman. LH 7:2 Monocional antibodies detects type VII collagen in the basement membrane of ectodermally-derived epithelia, including skin. Epithelia 1988; 1: 17-29

16. Lunstrum GP, Sakai LY, Keene DR, Morris NP, Burgeson RE. Large complex globular domains of type VII procollagen contribute to the structure of anchoring fibrils. J Biol Chem 1986; 261: 9042-9048.

17. Burgeson RE, Morris NP, Murray LW, Duncan KG, Keene DR Sakai LY. The structure of type VII collagen. Ann N Y Acad Sci 1986; 460: 47-57.

18. Smith LT, Sakai LY, Burgeson RE, Holbrook KA. Ontogeny of structural components at the dermalepidermal junction in human embryonic and tetal skin: the appearance of anchoring fibrils and type VII collagen. J Invest Dermatol 1988; 90: 480-485.

19. Gipson IK, Spurr-Michaud SJ. Tisdale AS. Hemidesmosomes and anchoring fibril collagen appear synchronously during development and wound healing. Develop Biol 1988; 126: 253-262.

20. Kirkham N, Price ML, Gibson B, Leigh IM, Coburn P. Darley CR. Type VII collagen antibody LH 7.2 identifies basement membrane characteristics of thin malignant medanomas. J Pathol 1989; 157: $243-247$. 


\section{LEGENDS TO THE FIGURES}

Figure 1. Adenoma of the colon. Regular type Vil collagen immunoreactivity lining the epithelium of the glands. No immunoreactivity of the stromal blood vessels (a). Regular type IV collagen immunoreactivity lining the gland epithelium. Stromal vessels are positive (b). 125x, immunofluorescence

Flgure 2. Adenoma of the colon. More intense type VII collagen immunoreactivity at the more superficial parts of the glands (type VII collagen, rhodamine labelled). 125x, immunofluorescence

Flgure 3. Mucosa adjacent to the adenomatous epithelium. Type VII immunoreactivity at the intertace between epithelium and stroma at the luminal surface. (type VII collagen, rhodamine labelled). 125x, immunofluorescence

Flgure 4. Adenocarcinoma of the colon. Only patches of immunoreactivity lining the neoplastic glands. In the stroma immunoreactive vascular basement membranes are seen. (type IV collagen. FITC labelled). 125x, immunofluorescence

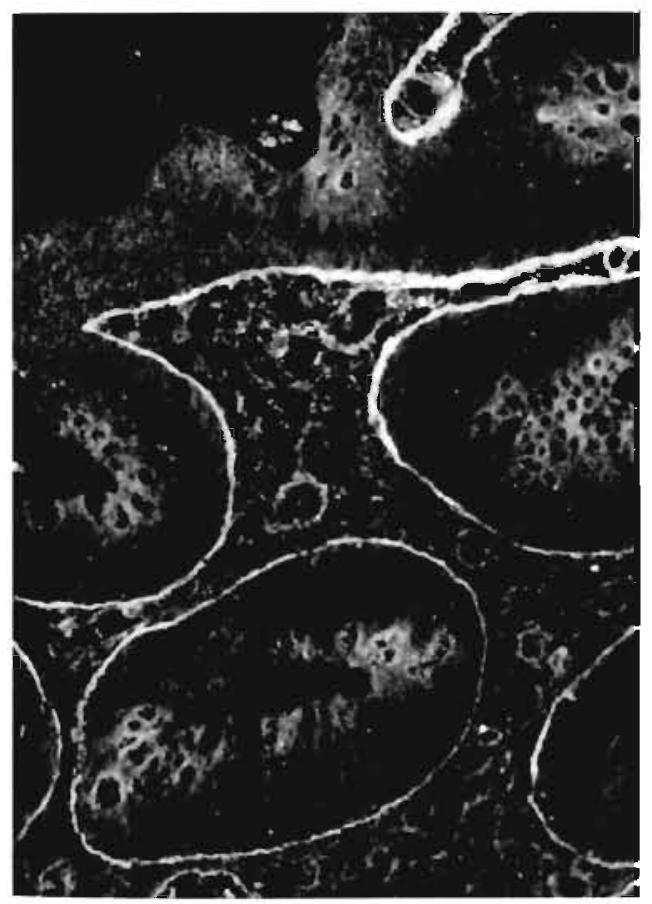

Figure 1a



Figure 1b 



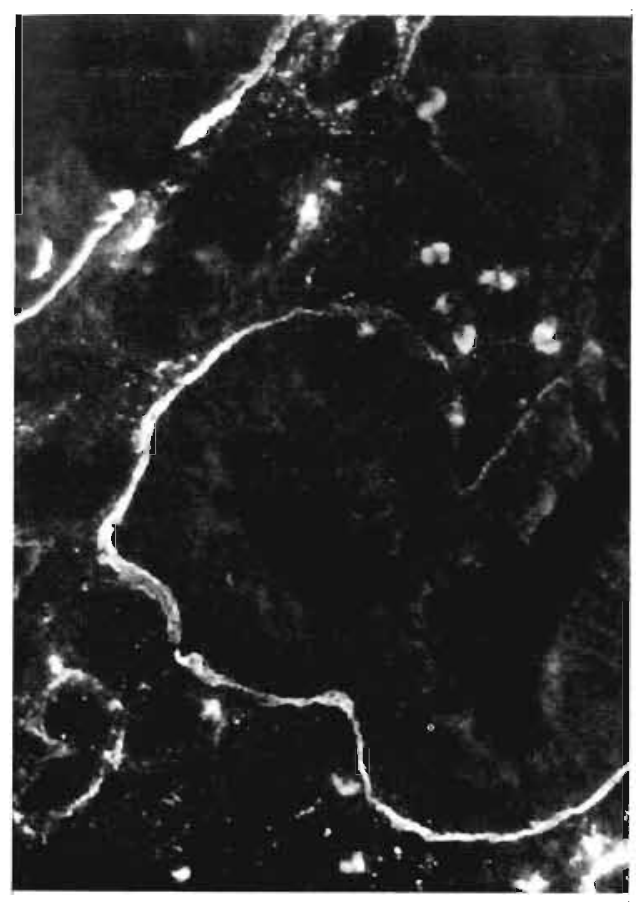

Flgure 2

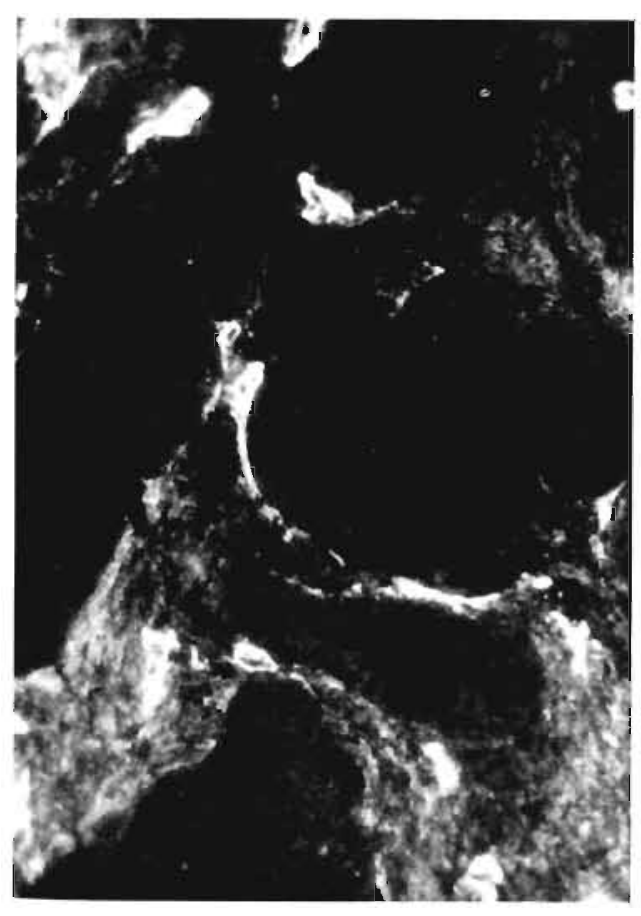

Figure 4

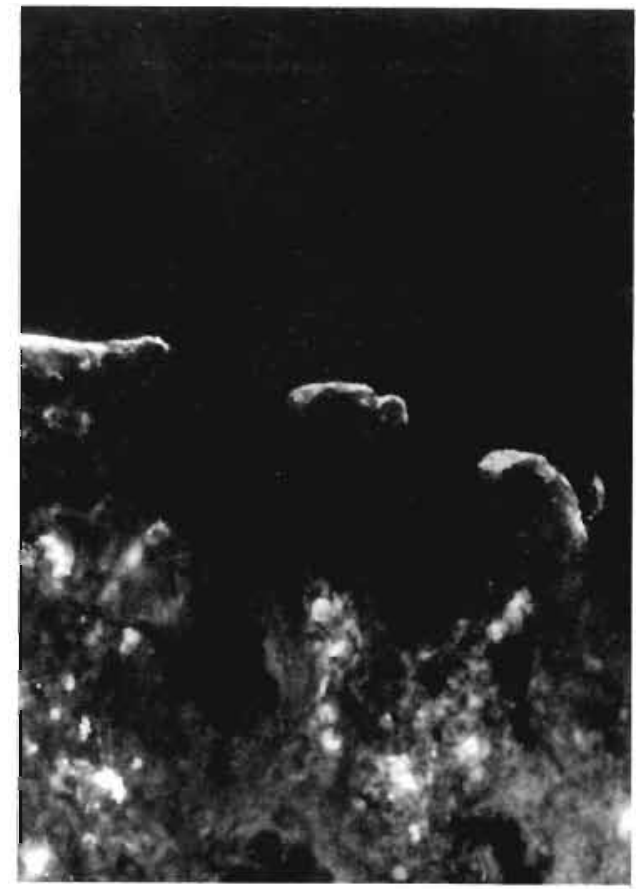

Figure 3 



\section{CHAPTER 7}

\section{TYPE VII COLLAGEN EXPRESSION IN THE NORMAL, HYPERPLASTIC AND NEOPLASTIC ENDOMETRIUM}

An immunohistochemical study with type VII collagen and type IV collagen antibodies in preneoplastic and neoplastic lesions of the endometrium.

R. Visser, MPML Snijders, JW Arends, FT Bosman

Submitted for publication 
The glandular epithelium and the vascular endothelium in the stroma of the endometrium are supported by intact and continuous basement membranes throughout the menstrual cycle.

These basement membranes contain intrinsic components such as laminin, type IV collagen and heparan sulphate proteoglycan (1-4). In addition, it has been shown that in the secretory phase and in pregnancy pericellular deposition of these matrix components occurs around decidualized stromal cells (2). In benign (pre)neoplastic conditions, the epithelial basement membranes remain patent as for example in simple hyperplasia and in atypical hyperplasia of the endometrium.

Some authors, however, observed minor interruptions in the epithelial basement membrane in simple hyperplasia $(1,3,4)$, but this phenomenon was also found in association with inflammation and stromal fibrosis (3). Interruptions in the basement membrane of neoplastic glands in endometrial carcinoma have been observed (3). The extent of these interruptions has been correlated with the grade of differentiation of the tumor: in poorly differentiated adenocarcinomas of the endometrium little or no basement membranes were detectable, whereas in well differentiated adenocarcinomas extensive basement membrane deposition occurred. These studies were executed by immunohistochemistry using antibodies against type IV collagen and laminin.

Type VII collagen, which is a major component of the anchoring fibrils, which bind the basement membrane to the underlying extracellular matrix, has been found almost exclusively in the basement membrane zones of stratified epithelia (7). In the female genital tract, type VII collagen expression has only been described in the cervical mucosa $(8,9)$. The occurrence and distribution of this anchoring fibril associated protein in non-stratified epithelia such as the glands of the endometrium has not been extensively described yet.

We therefore studied type VII collagen distribution in normal and neoplastic endometrium, addressing the following questions:

1- Does type VII collagen occur in the endometrium and if so, is the expression pattern related to the menstrual cycle.

2- Is the expression pattern of type VII collagen in the basement membrane altered in hyperplasia, atypical hyperplasia and adenocarcinoma of the endometrium in comparison with that of type IV collagen.

\subsection{MATERIALS \& METHODS}

\subsubsection{Endometrial mucosa}

For this study we used endometrial tissues obtained from patients which were treated because of essential menorrhagia, dysmenorrhoea or uterine descensus. Details on menstrual history, date of last menstrual period, hormonal therapy and gynaecological surgery were recorded. All 15 premenopausal women (between 29 and 46 years of age) had a regular menstrual cycle; the 5 postmenopausal women were between 51 and 66 years of age. None of the patients had a history of exogenous hormonal therapy or distortion of the endometrial cavity (curettage, IUD etc.) for at least two cycles before surgery. Immediately after surgery (De Wever Hospital, Heerlen), the removed uteri were opened. Besides sections for routine histopathological evaluation, another two samples including endometrium and adjacent myometrium were obtained from the uterine fundus and corpus. These samples were frozen in isopentane quenched in liquid nitrogen and stored at $-70^{\circ} \mathrm{C}$. Cryostat sections were cut at $4 \mu \mathrm{m}$, airdried at room temperature and stored at $-20^{\circ} \mathrm{C}$ for immunofluorescence doublestaining with antibodies directed against type IV collagen and type VII collagen. 
Routinely processed haematoxylin and eosin (H\&E) stains were used for histopathological evaluation. None of the uteri revealed any abnormalities. The endometrial dating criteria as described by Noyes et al (9) were used to assess the phase of the menstrual cycle in sections of the midfundus region. The histological appearance of the endometrium was classified as follows:

I : menstruation(days 1-5)

II : early proliferative (days $6-9$ )

III: late proliferative (days 10-14)

IV : early secretory (days 15-18)

$\mathrm{V}$ : midsecretory (days 19-22)

VI : late secretory(days 23-28)

VII: postmenopausal

\subsubsection{Hyperplasia and adenocarcinoma}

Tissue sampling was performed as described for the group with normal endometrium. H\&E staining was performed in order to classify the endometrial hyperplasia and adenocarcinoma. Hyperplasia was classified according to the histopathological criteria described by Kurman and Norris (11). By definition, the glandular lining epithelium was devoid of cytological atypia. Hyperplastic lesions in which the lining epithelium did show atypia were classified as atypical hyperplasia. Endometrial adenocarcinomas were graded by two pathologists by consensus, according to the revised FIGO definitions (12).

\subsubsection{Antibodies}

Polyclonal antiserum directed against type IV collagen was raised in rabbits with human placental type IV collagen as immunogen. Characterization and immunospecificity have been described before (13).

Two monoclonal antibodies against type VII collagen were used in this study: NP-76, which reacts with the amino terminus of the NC-1 domain of the molecule, and LH $7.2(14)$. The antibodies were kindly provided by drs R.E. Burgeson (Portland, Oregon, USA; NP-76) and I.M. Leigh (London, G.B.; LH 7.2).

\subsubsection{Immunohistochemistry}

1. indirect immunoperoxidase staining:

Cryostat sections were fixed in $2.5 \%$ buffered formaldehyde for 10 minutes and washed in demineralized water. After dehydration in graded alcohol, endogenous peroxidase was blocked 15 minutes in $0.3 \%$ hydrogenperoxide in methanol. After washing in demineralized water the sections were incubated with the appropriate antiserum during 45 minutes at room temperature (anti-type IV collagen diluted 1:250, NP-76 1:500 and LH 7,2 1:10 in Tris buffered saline (TBS) with $1 \%$ bovine serum albumin (BSA) and $0,1 \%$ Tween to reduce background staining). After washing in TBS the peroxidase-labeled swine-anti-rabbit conjugate, detecting the polyclonal antibody, (1:150 diluted in TBS/BSA/Tween) and peroxidase-labeled rabbit-anti-mouse (both obtained from Dakopatts, Denmark) detecting the monoclonal antibody (1:200 diluted in TBS/BSATween) were applied. After washing in TBS the complex was visualized in a substrate solution containing $5 \mathrm{mg} D A B$, dissolved in $10 \mathrm{ml} \mathrm{Tris} / \mathrm{HCl}(\mathrm{pH} \mathrm{7.6}), 4 \mu \mathrm{l}$ of $30 \%$ hydrogenperoxide and $1 \mathrm{ml}$ Imidazole $(0.1 \mathrm{M}$ in Tris/HCL). The sections were then counterstained with Mayer's haematoxylin during 1 minute, dehydrated and mounted with Entellan (Merck, Germany). 
2. Indirect immunofluorescence doublestaining.

For type IV collagen and type VII collagen doublestaining the sections were first incubated with a mixture of anti-type IV collagen (1:250 diluted) and anti-type VII collagen(1:500 diluted), in TBS $/ 1 \%$ BSA $0,1 \%$ Tween.

As second layer a mixture was used of FITC labeled goat anti rabbit IgG (Nordic, 1:300 diluted) and rhodamine labeled goat anti- mouse IgG (TAGO Inc, Burlingame, Cal, USA; diluted 1:300). Specificity of the obtained immune reaction was controlled by identical incubation of parallel sections, but with TBS instead of the primary antibody.

The fluorescence patterns were photographed with a Leitz dialux fluorescence microscope using alternately FITC and rhodamine filter combinations.

\subsection{RESULTS}

All specimens immunostained for type IV collagen showed consistent staining of epithelial and vascular basement membranes. Moreover, pericellular immunoreactivity was observed around the smooth muscle cells of the myometrium. These patterns were taken as internal positive control.

\subsubsection{Normal mucosa}

Regular and continuous basement membranes were found bordering the epithelial cells of the glands, at the interface between epithelial cells and adjacent stroma (Fig 1). This pattern, observed with antibodies directed against type IV collagen, was consistent throughout the menstrual cycle and in the menopausal period.

The expression pattern of type VII collagen was different. Throughout the different phases of the menstrual cycle and postmenopausal phase the glands in the basal part of the mucosa lacked type VII collagen immunoreactivity completely. During the early proliferative phase no type VII collagen immunoreactivity was observed around any of the endometrial glands. From the late proliferative phase on, throughout the rest of the menstrual cycle, an increasing type VII collagen immunoreactivity was observed, only focal in the superficial parts of the glands and more intense and extensive with continuous immunoreactivity in the basement membrane of the epithelial cells at the luminal surface of the mucosa (Fig. 2). In the specimens of the postmenopausal endometrium, the deeper parts of the endometrial glands showed focal immunoreactivity, while the surface epithelium showed continuous type VII collagen immunoreactivity.

\subsubsection{Hyperplasia}

In hyperplasia, stained for type IV collagen, the epithelial basement membrane appeared to be continuous, irrespective of the presence of epithelial atypia. The same pattern of generally regular and intact epithelial basement membranes was observed by type VII collagen immunostaining. However, in specimina with celiular atypia of the tubules, areas with absent basement membrane immunoreactivity for type VII collagen were observed, while type IV collagen staining showed intact basement membranes (Fig. 3).

\subsubsection{Adenocarcinoma}

Adenocarcinomas of the endometrium showed irregular patterns of epithelial basement membrane staining, with interruptions up to total absence, when stained for type IV collagen (Fig 4). In 1 case of papillary adenocarcinoma, type IV collagen immunoreactivity was not observed around tumor epithelium.

In these specimina of endometrial adenocarcinoma type VII collagen immunoreactivity was not observed. 
In this study, we investigated basement membrane patterns in normal endometrium, and in endometrial hyperplasia and adenocarcinoma. Antibodies against type $\mathrm{V}$ collagen and lype VII collagen were used. Type VII collagen is the major constituent of anchoring fibrils $(7,15)$. These fibrils, which reinforce attachment of epithelial cells to the stroma, originate at the basement membrane and project into the stroma. Type VII collagen has been found in the basement membrane of amnion epithelium and in the basement membrane of stratified epithelia such as oesophageal, oral and cervical mucosa, corneal epithelium, urothelium of the urinary bladder and around ducts of the breast $(8,9,16)$.

Patterns of type VII collagen expression have been studied in a limited spectrum of neoplasms. Kirkham et al (17) described type VII collagen containing basement membranes surrounding tumor cell nests in malignant melanoma. In malignant melanomas exceeding $0.9 \mathrm{~mm}$ in thickness, these basement membranes appeared to be fragmented, suggesting a relationship between the thickness of the tumor, basement membrane integrity and a prognosis in thin malignant melanomas. Schmoeckel et al (18) found intact basement membranes around junctional tumor nests of melanomas, including weak staining with type VII collagen. In deeper, dermal regions they observed positive staining for laminin around the tumor nests, but weak staining for type IV collagen and absent type VII collagen immunoreactivity, suggesting a gradual disappearance of basement membrane components during the penetration of malignant melanoma cells in the dermis. Recently, we studied the presence and localization of type VII collagen in the normal mucosa, adenomas and adenocarcinomas of the large bowel (reported in Chapter VI of this thesis). Type VII collagen appeared to be transiently expressed in the development of neoplasia: no expression in normal epithelium, extensive expression in dysplastic, limited expression in well differentiated malignant and no expression in poorly differentiated malignant epithelium.

In the present investigation we studied the expression of type IV and type VII collagen in the normal endometrium and in endometrial hyperplasia and adenocarcinoma.

Our observations of type IV collagen immunoreactivity patterns are in line with findings of others $(1,2,3,4,19)$, who reported a homogeneous distribution of type IV collagen in the basement membrane of vascular structures in the stroma and of tubules and epithelia at the luminal surface.

The results of our study indicate, that an increasing amount of type VII collagen is expressed during the course of the menstrual cycle, with focal immunoreactivity in the epithelial basement membrane in the proliferative phase and continuous type VII collagen immunoreactivity in the basement membranes of the glands in the secretory phase, which is more intense at the luminal surface than around the deeper glands. This pattern differs from that of type IV collagen, which is expressed ubiquitously along the epithelial lining of glands and surface. This different expression pattern might reflect specific functions of type IV and VII collagen in the basement membrane. The association of type VII collagen with anchoring fibrils, which are found in the subbasal lamina and reinforce the attachment of epithelial cells to the underlying stroma of tissues subject to external frictional forces suggests that the presence of type VII collagen in the secretory phase of the menstrual cycle might be associated with shear forces in the uterine cavity. Alternatively, it could be envisaged that the function of type VII collagen is not merely mechanical, but also includes regulating properties.

In adenomatous hyperplasia various authors have reported intact basement membranes, although Furness and Lam (4) found disruptions in the basement membrane in some cases of adenomatous hyperplasia. In our series of adenomatous hyperplasia we did not find any basement membrane discontinuity in type IV collagen stained sections, even in the presence of cellular atypia. However, type VII collagen staining showed focal absence in cases of hyperplasia with atypia. 
This heterogeneous expression pattern of type IV and type VII collagen was more pronounced in adenocarcinoma of the endometrium. Basement membrane breaks up to total absence was observed in sections stained for type IV collagen, confirming results from the literature $(1-4,19)$. Type VII collagen expression, on the other hand, lacked completely in adenocarcinoma. The biological significance of this finding remains unanswered.

Our findings might have some diagnostic applications. The irregular type VII collagen staining we observed in atypical hyperplasia might be used to delineate the boundary between hyperplasia and adenocarcinoma. The disappearance of type VII collagen immunoreactivity in adenocarcinoma might be used in the same way.

In conclusion, we have found type VII collagen expression in the late proliferative and secretory endometrium, especially in connection with basement membranes of superficial glands. In hyperplasia this pattern remains, but in atypical hyperplasia type VII collagen gradually disappears and type VII collagen is no longer observed in endometrial adenocarcinoma. 
1. Bulletti C, Galassi A, Jasonni VM, Martinelli G, Tabanelli S, Flamigni C. Basement membrane components in normal, hyperplastic and neoplastic endometrium. Cancer 1988; 62: 142-149.

2. Faber M, Wewer UM, Berthelsen JG, Liotta LA, Albrechtsen R. Laminin production by human endometrial stromal cells relates to the cyclic and pathologic state of the endometrium. Am J Pathol 1086; 124: 384-391.

3. Vogel HP. Mendelsohn G. Laminin immunostaining in hyperplastic, oysplastic and neoplastic lesions of the endometrium and the uterine cervix. Obstet Gynecol 1987; 69: 794-799.

4. Fumess PN, Lam EW. Patterns of basement membrane deposition in benign, pre malignant and malignant endometrium. J Clin Pathol 1987; 40: 1320-1323.

5. Wewer UM, Damjanov A, Weiss J, Liotta LA, Damjanov I. Mouse endometrial stromal cells produce basement membrane components. Differentiation 1986; 32: 49-58.

6. Aplin JD, Chariton AK, Ayad S. An immunohistochemical study of human endometrial extracellular matrix during the menstrual cycle and first trimester of pregnancy. Cell Tissue Res 1988; 253: 231-240.

7. Burgeson RE, Morris NP, Murray LW, Duncanc KG, Keene DR, Sakai LY. The structure of type VII collagen. Ann NY Acad Sci 1985; 460: 47-57.

8. Sakai LY, Keene DR, Morris NR, Burgeson RE. Type VII collagen is a major structural component of anchoring fibrils. J Ceil Biol 1986; 103: 1577-1586.

9. Wetzels RHW, Robben HCM, Leigh IM, Schaafsma E, Vooijs GP, Ramaekers FCS. Distribution patterns of type VII collagen in normal and malignant human tissues. Am \& Path 1991; 139: 451-559.

10. Noyes RW, Hertig AT, Rock J. Dating the endometrial biopsy. Fertil Steril 1950; 1: 3-10.

11. Kurman RJ, Norris HJ. Endometrial hyperplasia and metaplasia. in: Kurman RJ, ed. Blaustein's Pathology of the female genital tract. 3rd ed New York: Springer Verlag, 1987: 322-337.

12. Sheperd JH. Revised FIGO staging for gynaecological cancer. Br J Obstet Gynaecol 1989; 96: 889-892.

13. Havenith MG, Cleutjens JPM, Beek C, v.d.Linden E, de Goey AFPM, Bosman FT. Human specific anti-type IV collagen monocional antibodies. Characterization and application to immunohistochemistry. Histochemistry $1987 ; 87: 123-128$.

14. Leigh IM, Purkis PE, Bruckner-Tuderman L, LH 7.2 monoclonal antibody detects type VII callagen in the basement membrane of epidermally derived epithelia including skin. Epithelia 1988; 1: 17-29.

15. Lunstrum GP, Sakai LY, Keene DR, Morris NP, Burgeson RE. Large complex globular domains of type VII procollagen contribute to the structure of anchoring fibrils. J Biol Chem 1986; $261: 9042-9048$.

16. Wetzels RHW, Holland R, van Haelst UJGM, Lane EB, Leigh IM, Ramaekers FCS. Detection of basement membrane components and basal cell keratin 14 in nonin vasive and invasive carcinoma of the breast. Am $J$ Pathol 1989; 134: $571-580$.

17. Kirkham N, Price ML, Gibson B, Leigh IM, Coburn P, Darley CR. Type VII collagen antibody (LH 7-2) identifies basement membrane characteristics of thin malignant melanoma. J Pathol 1989; 157: 243-247.

18. Schmoeckel C, Stolz W, Sakai LY, Burgeson RE, Timpl R, Krieg T. Structure of basement membranes in malignant melanomas and nevocytic nevi. $J$ Invest Dermatol 1989; 92: 663-668.

19. Stenbäck F. Risteli J, Risteli L. Wasenius VM. Basement membrane laminin and type IV collagen in endometrial adenocarcinoma, relation to differentiation and treatment. Oncology 1985; 42: 370-376. 


\section{LEGENDS TO THE FIGURES}

Flgure 1. Normal proliferating endometrium. Intact basement membranes around glands and vessels. Type IV collagen immunofluorescence $(63 x)$.

FIgure 2. Superficial epithelium of the endometrium. a: continuous immunoreactivity for type VII collagen. Note absence of immunoreactivity around stromal vessels. b: Continuous immunoreactivity for type IV collagen. Note immunoreactive vascular basement membranes (immunofluorescence, 125x).

Figure 3. Endometrium with hyperplasia and cellular atypia, a: Extensive basement membrane immunoreactivity for type IV collagen. b: Reduced and partially absent immunoreactivity for type VII collagen (immunofluorescence, $125 x$ ).

Flgure 4. Adenocarcinoma of the endometrium. Irregular patterns of type IV collagen deposition around neoplastic glands (immunoperoxidase; type IV collagen, 125x).



Figure 1 


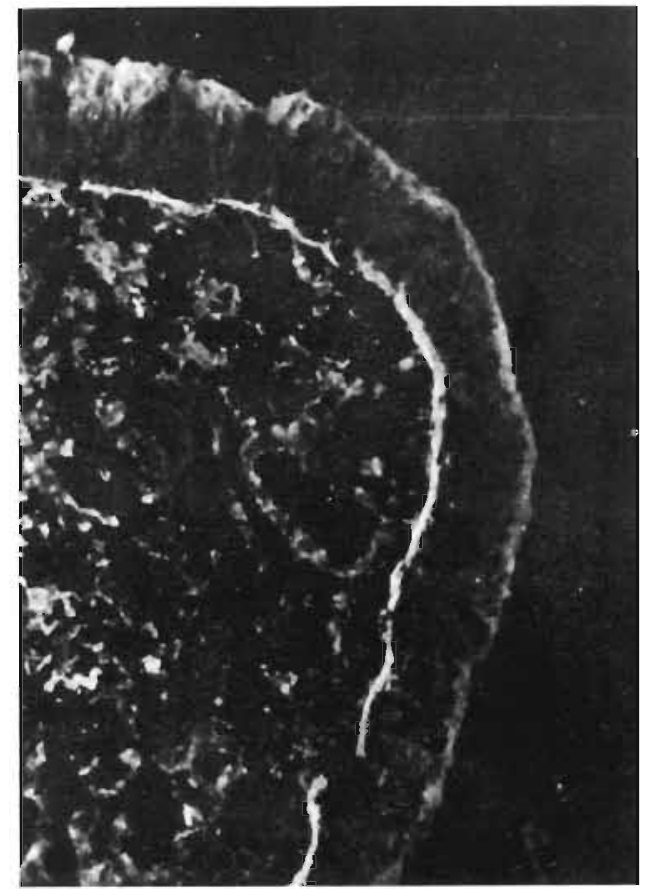

Figure $2 a$

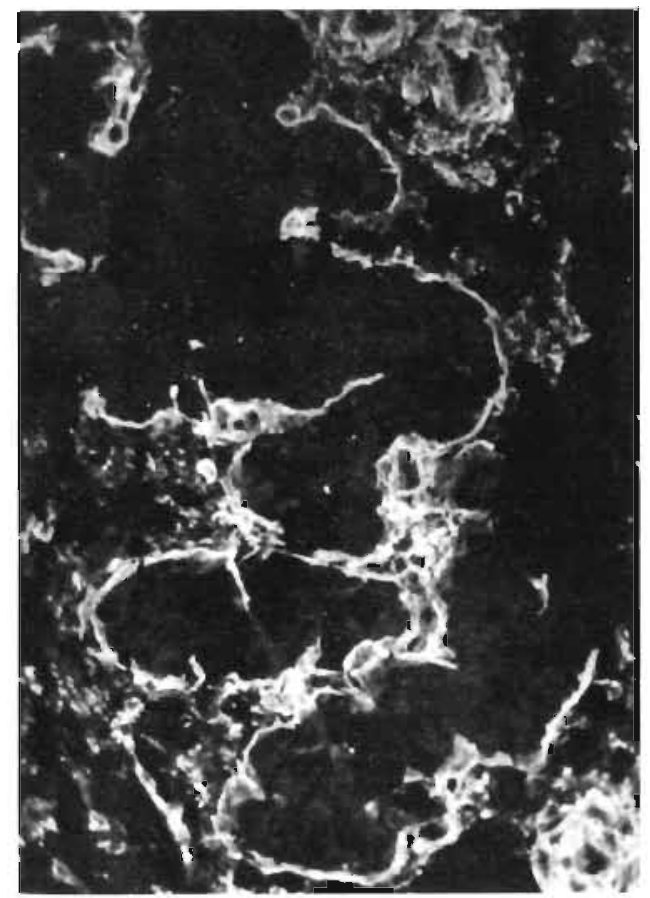

Figure 3a

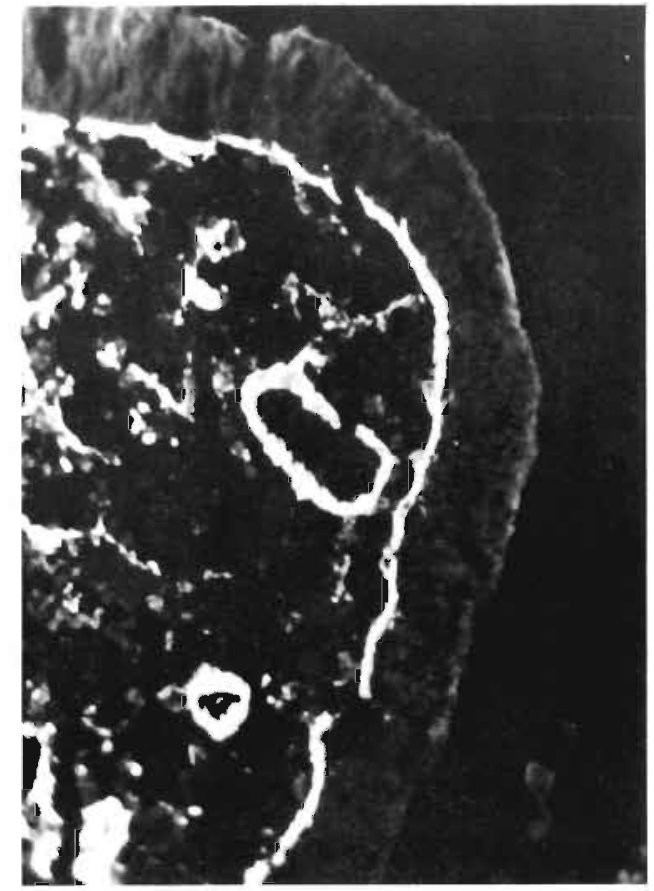

Figure 2b

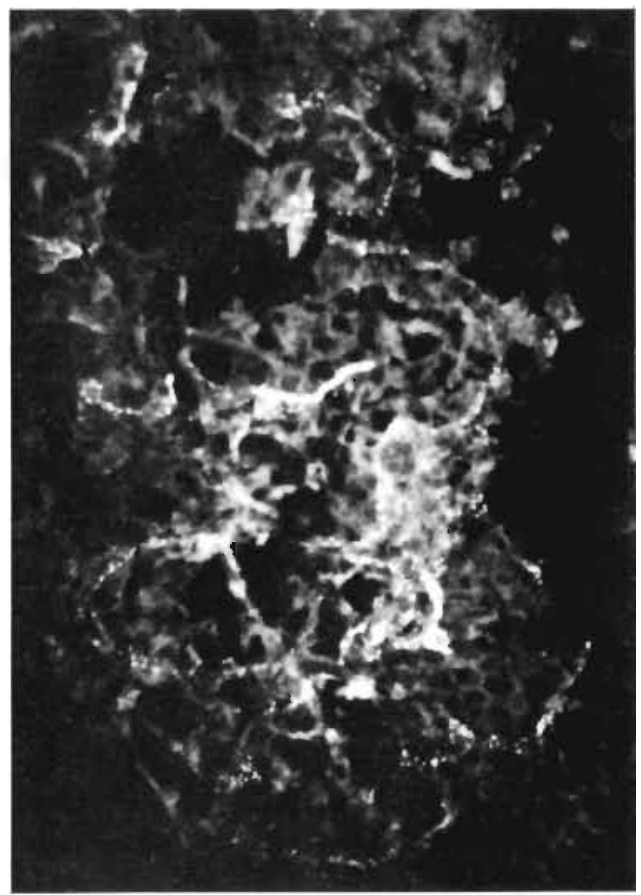

Figure 3b 



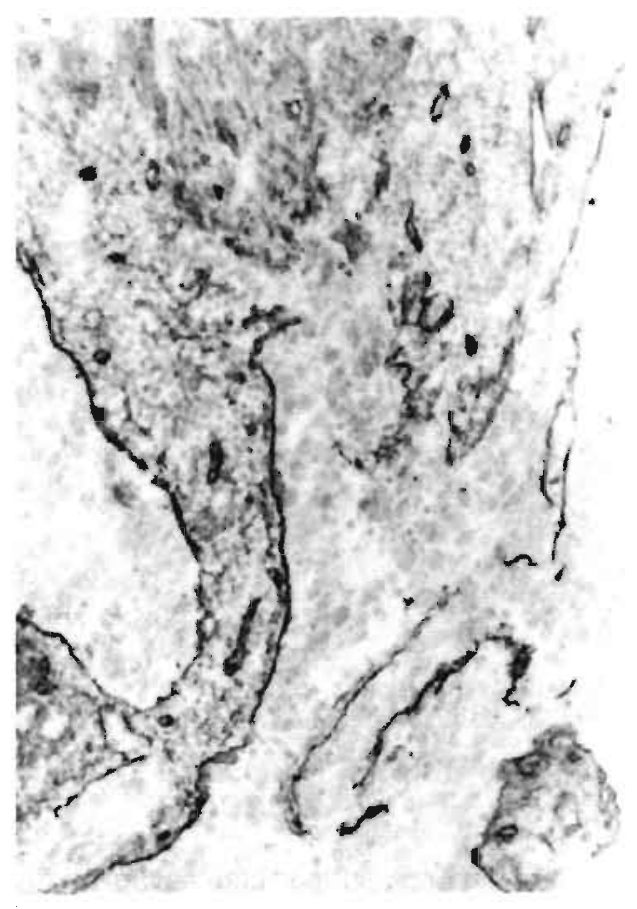

Flgure 4 



\section{CHAPTER 8}

\section{GENERAL DISCUSSION}

\subsection{BASEMENT MEMBRANE PATTERNS IN BENIGN AND MALIGNANT NEO- PLASMS}

An essential feature of benign epithelial neoplasia is its restriction to the epithelial compartment which implies absence of invasion. Consequently, it may be expected that immunohistochemical staining of the basement membrane will invariably reveal intact basement membranes in benign tumors. This has indeed been confirmed in many studies on noninvasive benign epithelial tumors of various tissues including the skin, breast, uterine cervix and larynx. Two examples of this principle, which illustrate the use in daily practice, are breast neoplasms, where intact basement membranes allow the distinction between sclerosing adenosis and tubular carcinoma and pancreatic lesions, where basement membrane immunohistochemistry facilitates the discrimination between chronic fibrosing pancreatitis and adenocarcinoma of the pancreas. However, it has also been reported that in benign conditions, such as epithelial dysplasia, interruptions occur. Also in inflammatory conditions basement membrane gaps are found, presumably due to proteolytic properties of migrating inflammatory cells.

In contrast, basement membrane degradation is regarded as a decisive step towards the development of malignant neoplasia, because it precedes tumor invasion. Invasive tumors may show variable basement membrane patterns, ranging from almost total absence, as has been described in tubular carcinoma of the breast, to almost complete enveloping of tumor cell nests with an irregular, but largely intact basement membrane, as in malignant melanomas.

\section{POTENTIAL SIGNIFICANCE OF BASEMENT MEMBRANE PATTERNS IN TUMORS OF BORDERLINE MALIGNANCY}

Contrasting with the extensive biochemical and cell biological research in the field of tumor cell/extracellular matrix interaction, and with the numerous studies reporting basement membrane patterns in malignant neoplasms, relatively few immunohistochemical studies have been executed to investigate basement membrane characteristics in neoplasms on the borderline between benign and malignant. Structural basement membrane alterations, such as reduplication and focal interruption, have been described in epithelia with severe dysplasia or in in situ carcinomas as well as in epithelial tumors of borderline malignancy. 
In this stage cf tumor cell evolution, when the neoplastic cells may transit from a noninvasive into an invasive phenotype, complex alterations occur in the relation between the neoplastic cell and its surrounding extracellular matrix, which creates a suitable microenvironment for invasive growth. Gaps in the basement membrane are caused by basement membrane remodelling due to decreased synthesis and assembly of its components, or, alternatively, basement membrane dissolution may be due to matrix-degrading enzymes such as collagenases, cathepsins, plasmins and heparanases, which are secreted by tumor cells.

If in this initial phase of tumor progression the basement membrane is visualized, a distinction might be envisioned between lesions with an intact basement membrane, to be regarded as benign, and lesions with basement membrane defects, to be regarded as malignant. This would indicate that the term borderline lesion signifies the inability of the pathologist to determine the biological potential of a lesion by routine histology. That problem might then be solved by basement membrane immunohistochemistry. An alternative view is that borderline lesions constitute a biological intermediate between benign and malignant, undetermined in their biological behaviour. The primary aim of our study was to test the first hypothesis i.e. that borderline lesions can be distinguished by basement membrane immunohistochemistry in an intrinsically benign and a potentially malignant group.

Using antibodies directed against specific basement membrane components, including laminin, type IV collagen and type VII collagen immunohistochemical studies were executed in tumors of the larynx, ovary, kidney, colon and endometrium.

\subsection{OBSERVED BASEMENT MEMBRANE PATTERNS IN TUMORS OF BORDER- LINE MALIGNANCY}

In the larynx we investigated hyperplasia, dysplasia and in situ carcinoma of the mucosa. Distinct and continuous basement membranes were found with anti laminin and type IV collagen antibodies in normal epithelium as well as in hyperplasia and dysplasia. Besides basement membrane discontinuity in invasive carcinomas but also in some cases of in situ carcinoma, focal interruptions were observed in areas with adjacent inflammation.

The first observation supports our hypothesis, although follow-up studies have to be performed to test the validity of the assumption that in situ carcinomata with basement membrane interruptions stand a higher chance to progress towards invasive carcinoma than those with intact basement membranes. The second observation indicates that basement membrane interruptions only, can never be taken as convincing evidence of malignant behaviour.

We furthermore studied borderline malignant tumors of the ovary. We studied basement membrane patterns in these tumors and compared them with those in ovarian cystadenomas and cystadenocarcinomas.

In cystadenomas regular and intact basement membranes were found. Cystadenocarcinomas displayed irregular and interrupted basement membranes intermingled with areas of intact basement membranes. Of the borderline tumors $70 \%$ shared a regular and intact basement membrane pattern with cystadenomas, However, $30 \%$ of the borderline malignant tumors contained small areas with an irregular and interrupted basement membrane pattern, resembling that of invasive carcinoma.

We conclude that also in ovarian tumors of borderline malignancy basement membrane patterns mostly are intact and therefore similar to those of benign epithelial tumors. Focal irregular defects, possibly suggesting early invasive growth, however, occur in $30 \%$ of the cases.

As in the laryngeal in situ carcinoma, follow-up studies have to confirm the predictive value of basement membrane staining patterns for the prediction of the behaviour of the neoplasm. We next investigated basement membrane patterns in small renal adeno- 
carcinomas. Based on these patterns, two groups could be discriminated. One group of tumors contained intact and regular basement membranes and the other group showed irregular and/or focally absent basement membranes. A statistically significant correlation was found between basement membrane pattern and tumor size as well as nuclear grade, both parameters correlating with metastatic potential. Therefore, even though also in these tumors follow-up studies were not conducted, we conclude that in small renal cortical neoplasms basement membrane interruptions might be indicative of malignant potential.

Taken together, these three studies indicate that histopathological borderline categories might contain distinct subpopulations with, on the basis of basement membrane patterns, identifiable differences in behaviour. Our studies also illustrate a practical problem in validation of this assumption in obtaining sufficient material to conduct adequate follow-up studies. Two other studies were conducted in order to elucidate the potential role of type VII collagen depositions in lesions progressing from non-invasive to invasive.

Type VII collagen, the major component of anchoring fibrils, is mainly found in association with surface epithelium. Its expression has been studied by other investigators in carcinoma of larynx, endometrium and large bowel. We noted in squamous cell carcinoma of the larynx a difference in the patterns of expression of type IV collagen and type VII collagen, which was most pronounced in poorly differentiated tumors. Basement membranes in sections stained for type VII collagen showed discontinuities whereas staining for type IV collagen showed intact basement membranes, suggesting that type VII collagen is a better indicator for early invasive growth. It also appeared that in poorly differentiated carcinoma intracytoplasmic expression of type VII collagen occurs in the absence of type IV collagen reactive basement membranes.

In the endometrium type VII collagen appeared gradually in the course of the menstrual cycle, along with intact basement membranes as reflected in the pattern of staining for type IV collagen. In atypical hyperplasia, extensive deposition of type VII collagen was found, which gradually disappeared in adenocarcinoma. As in squamous carcinoma of the larynx, type VII collagen deposition therefore might be related to epithelial differentiation.

Although the epithelial basement membrane of normal mucosa of the large bowel lacks type VII collagen, this component was evidently transiently expressed in areas of dysplasia as for example in adenomas.

The overall conclusions of these studies is that the relationship of basement membrane staining and morphologically detectable tumor cell invasion is highly complex, with basement membrane interruptions in inflammation, severe epithelial dysplasia, in situ carcinoma and in invasive carcinoma. Therefore, invasive malignant neoplasia cannot be diagnosed solely on disruptions in the basement membrane.

\subsection{FUTURE PERSPECTIVE}

Basement membrane morphology is only one aspect of the complex interaction between tumor cells and the extracellular matrix and provides a fairly static view on a dynamic process: altered balance between basement membrane assembly and degradation. Recent studies have revealed ample information concerning the proteases and glycosidases (a.o.) that are synthesized and released by tumor cells and stromal cells and are associated with initiation of tumor invasion. Also the matrix, adjacent to the tumor cells is changed and becomes permissive for the tumor cells to migrate. In this sequence of events during initial invasion of tumor cells cell adhesion molecules and motility factors play an important role. It is this area, that future studies might result in new insight in the interaction between tumor cells and their surrounding matrix. Identification of new matrix-degrading enzymes, unravelling of the role of plasminogen activators and plasmin, the significance of motility factors and new information on cell-adhesion molecules and integrin extracellular matrix receptors will extend our understanding of tumor cell invasion and provide us with tools for more accurate tumor diagnosis and determination of tumor behaviour. 
, 


\section{SUMMARY}

h this hesis 6 studies are reported conceming the gondion of the basement membram in

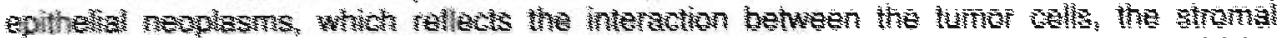

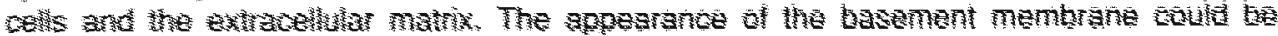

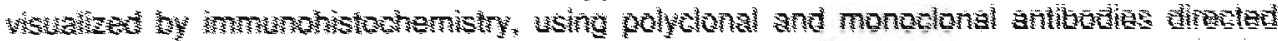

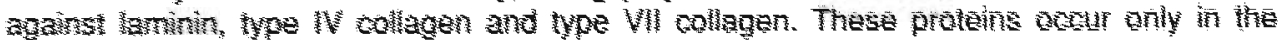
basement nombrane.

As this method has been extensively used to study inwaive tumors wis limited out

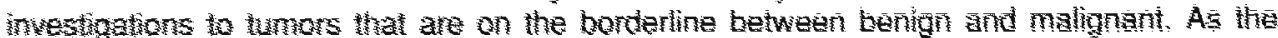


which do not visualize the basement membrane, the aim of ou suduas was to subdivide

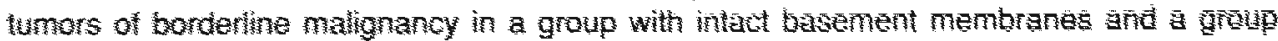
with interrupted basement membranes. If the difference would correlate with a different, more aggressive biological behaviour, being reflected by interruptions of the basement membrane, this would be of diagnostic importance.

In Chapter 1 the aims of the studies are defined and the structure, composition and function of the basement membrane is outlined. Presently, it is generally accepted that the basement membrane is not a static border between epithelial cells and the adjacent stroma, but a dynamic structure, which appears to be continuously synthesized and degraded. The balance between synthesis and degradation is grossly disturbed in malignant conditions.

Finally, an overview is presented of the basement membrane patterns in benign and malignant tumors and a review of the literature concerning basement membrane patterns in tumors of borderline malignancy.

Chapter 2 describes basement membrane patterns in the larynx: biopsies with normal mucosa, dysplasia and in situ carcinoma were studied. As could be anticipated, intact basement membranes were found in the normal mucosa, both with laminin and type IV collagen. Basement membranes in dysplastic epithelium also appeared to be continuous, but defects were observed in carcinoma, in some cases of in situ carcinoma and in areas of inflammation. It was concluded that basement membrane immunohistochemistry could be of value for the demonstration of microinvasive growth in laryngeal cancer, but that the basement membrane can also be degraded by inflammatory cells.

Chapter 3 reports basement membrane patterns in 3 groups of lumors of the ovary: cystadenomas, cystadenocarcinomas and tumors of borderline malignancy. Antisera were used against laminin and type IV collagen. Cystadenomas displayed intact basement membranes. In cystadenocarcinomas, serous and mucinous, a different pattern was observed: areas with irregular or absent basement membranes but also deposition of basement membranes between tumor cells and stroma. Tumors with borderline malignancy shared a regular basement membrane pattern with cystadenomas. However, thirty percent of this group contained small areas where basement membranes were lacking, resembling the pattern of cystadenocarcinomas. 
From the results of this study, we conclude, that the basement membranes in cystadenomas are intact, while cystadenocarcinomas contain irregular basement membranes. Tumors of borderline malignancy can be subdivided into a group that contains intact basement membranes (like cystadenomas) and a group in which irregular basement membranes are found (resembling patterns in cystadenocarcinomas).

Chapter 4 describes a study of basement membranes patterns in a group of small renal cortical tumors of which the biological behaviour is unpredictable. Several investigators studied the possibility of a correlation between tumor size, stage, histological subtype and karyotype on the one side and clinical parameters of tumor behaviour on the other. This, however, has not resulted in the identification of parameters, which unambiguously distinguish benign from malignant lesions.

In principle the presence or absence of invasive growth might provide a more reliable parameter of tumor behaviour. In order to investigate this possibility, we executed an immunohistochemical study of basement membrane patterns in small renal cortical neoplasms with emphasis on patterns in the centre and the periphery of the tumor. We furthermore studied the relation between deposition of basement membrane components and nuclear grade, which in stage 1 tumors can distinguish between high grade, more frequently metastasizing tumors and low grade, less frequently metastasizing tumors.

The results of our study show that, on the basis of basement membrane patterns, two groups can be distinguished. One group of tumors contains intact basement membranes similar to in situ carcinomas and the other group shows focally or totally absent basement membranes, corresponding with tumors with invasive growth. Tumors with low nuclear grade mostly contain regular and intact basement membranes, in contrast to high grade tumors.

In Chapter 5 the presence of type IV collagen and type VII collagen was assessed in the basement membrane of the upper respiratory tract mucosa and the distribution pattern of these components was evaluated in squamous cell carcinoma of this region.

Basement membrane patterns were investigated, using immunohistochemical methods, and their presence was assessed semi-quantitatively in relation to tumor cell differentiation. Coexpression of type IV collagen and type VII collagen was studied using double immunofluorescence.

The results indicate that the expression of the two basement membrane components is correlated and is also dependent on tumor cell differentiation: with decreasing level of differentiation the tendency of tumor cells to deposit basement membrane material decreases. In poorly differentiated tumors some cells with intracellular deposition of type VII collagen fail to deposit this component extracellularly.

The findings of this study suggest that type VII collagen might be a more sensitive indicator for invasive growth than type IV collagen, because it disappears earlier. Furthermore the results indicate that type VII collagen synthesis is regulated independent from type IV collagen synthesis, but its extracellular deposition appears to depend on the availability of a type IV collagen matrix. Intracytoplasmic type VII collagen expression might be used as a progression marker for squamous cell carcinoma.

In Chapter 6 the distribution of type IV collagen and type VII collagen in the basement membranes of normal mucosa of the colon, adenomas and adenocarcinomas is described, using immunoperoxidase and immunofluorescence techniques. In normal mucosa we found regular type IV collagen positive basement membranes, lining vascular structures and mucosal epithelia. These basement membranes, however, lacked type VII collagen.

In adenomas of the colon intact basement membranes were observed through type IV collagen staining. Type VII collagen staining was also detected, but only in connection with dysplastic epithelium. Adjacent to the dysplastic epithelium in adenomas, histologically normal epithelium also showed type VII collagen staining along the basement membrane, but restricted to the epithelium of the luminal surface. These areas were also investigated for expression of keratins 8,18 and 19 and keratins 5 and 8 (monoclonal antibodies NCL- 
5D3 and RCK 102 respectively), but altered differentiation was not detected using this technique.

In adenocarcinomas of the colon, type IV collagen was irregularly deposited in the basement membrane of neoplastic tubules. Type VII collagen staining was only detected in well or moderately differentiated carcinomas and in higher amounts.

Our findings, therefore, reveal a transient expression of type VII collagen in the transition of dysplastic epithelium into carcinoma, suggesting the involvement of type VII collagen in the process of early invasion.

In Chapter 7 the staining patterns for the basement membrane components type IV and type VII collagen in the different phases of the menstrual cycle were studied immunohistochemically using an indirect immunoperoxidase technique as well as immunofluorescence doublestaining. In addition the staining patterns in hyperplasia and adenocarcinoma of the endometrium were investigated.

The normal endometrium showed epithelial basement membranes with continuous staining for type IV collagen. However, type VII collagen was only present in epithelial basement membranes in the superficial layer of the lamina functionalis of the endometrium only in the late proliferative phase and in the secretory phase. Hyperplastic endometrium showed continuous basement membranes when stained both for type IV collagen and type VII collagen. However, in areas with cellular atypia discontinuities were found in the basement membranes when stained for type VII collagen. Staining for basement membrane components was even more abnormal in adenocarcinomas of the endometrium, where type IV collagen staining was discontinuous, while type VII collagen was completely absent.

Our results indicate that type VII collagen is more widely distributed than previously assumed. Furthermore, in the development of endometrial neoplasia basement membrane abnormalities are reflected earlier in type VII collagen than in type IV collagen deposition. The potential for diagnostic use of this finding needs to be further investigated.

In chapter 8 an overview is given of basement membrane characteristics in benign and malignant neoplasms. Basement membrane patterns in tumors of borderline malignancy are discussed with respect to their possible biological behaviour and potential diagnostic significance. Finally, the potential role of type VII collagen depositions in lesions progressing from non-invasive to invasive were discussed. 



\section{SAMENVATTING}

In dit proefschrift worden de resultaten beschreven van een zestal immunohistochemische studies op het gebied van veranderingen van de basaalmembraan in epitheliale tumoren. Omdat, blijkens omvangrijke literatuur, reeds vrij veel onderzoek werd verricht naar de verschijningsvormen van de basaal membraan bij invasief groeiende tumoren, hebben wij de nadruk bij onze studies gelegd bij processen met beginnende en (bij conventionele kleuringsmethoden) onzekere kwaadaardigheid, respectievelijk "carcinoma in situ" en "borderline tumoren".

De basaal membraan kon hierbij specifiek zichtbaar worden gemaakt met behulp van immunohistochemie op weefselcoupes, waarbij gebruik werd gemaakt van polyclonale en monoclonale antilichamen, gericht tegen basaalmembraan-specifieke eiwitten als laminine, type IV collageen en type VII collageen.

In hoofdstuk 1 wordt het onderzoeksgebied ingeleid. De structuur en samenstelling van de basaalmembraan wordt beschreven op geleide van de in de literatuur beschikbare gegevens. Ook wordt gewezen op de dynamiek van de basaalmembraan en de relatie en interactie met de extracellulaire matrix en de cellen, die met de basaalmembraan geassocieerd zijn. Deze onderlinge beinvloeding vindt ook plaats onder omstandigheden, waarbij de normale ontwikkeling van de cellen verstoord is. In dit gebied is reeds veel onderzoek verricht, de laatste tien jaar. Er wordt een uitgebreid overzicht gegeven over de resultaten van dit onderzoek, zowel bij goedaardige als kwaadaardige tumoren en er wordt een overzicht gegeven van de reeds verschenen publikaties op het gebied van grensvlaktumoren en tumoren van onzekere kwaadaardigheid. Het hoofdstuk wordt besloten met een uitgebreide lijst van publikaties op dit gebied.

Hoofdstuk 2 bevat de beschrijving en resultaten van een onderzoek naar het patroon van de basaal membraan in normaal slijmvlies van de larynx, bij hyperplasie, dysplasie en carcinoma in situ, waarbij gebruik werd gemaakt van antilichamen gericht tegen laminine en type IV collageen. Een regelmatig patroon van de basaal membraan werd gezien in normaal slijmvlies. Hierbij werd de basaal membraan gezien als een smalle, streepvormige en ononderbroken structuur. De patronen bij de immunohistochemische kleuringen met laminine en type IV collageen waren identiek. Ononderbroken basaal membranen werden ook aangetroffen bij dysplastisch epitheel, terwijl defecten waargenomen werden bij het carcinoom. Bij het carcinoma in situ bleek de basaal membraan in sommige gevallen en op gelokaliseerde plaatsen defecten te bevatten. Daarnaast is gebleken, dat basaal membraandefecten ook konden ontstaan in gebieden met ontstekingsactiviteit. In de gevallen, waar dit waargenomen werd, toonde het bekledende epitheel hyperplastische of dysplastische kenmerken, maar ook in gevallen met carcinoma in situ, waarbij een ontstekingscomponent aanwezig was.

De waarde van deze methode bij de histopathologische diagnostiek van deze groep van aandoeningen in de larynx werd bediscussieerd.

In hoofdstuk 3 is het onderzoek gericht op basaal membraanpatronen bij ovariumtumoren van "borderline" maligniteitsgraad. De verkregen resultaten werden vergeleken met basaal 
membraan patronen bij cystadenomen en cystadenocarcinomen van het ovarium. Er werd gebruik gemaakt van antilichamen gericht tegen laminine en type IV collageen. In tegenstelling tot de groep van de cystadenomen, waarbij de basaal membraan regelmatig gevormd en overal intact bleek, was het expressiepatroon bij de groep van de cystadenocarcinomen onregelmatig en op talrijke plaatsen afwezig.

Het patroon van de basaal membraan bij de groep van ovariumtumoren met "borderline" maligniteit toonde in principe een identiek beeld als in de groep cystadenomen. Echter bleek in $30 \%$ van de gevallen de basaal membraan onregelmatige defecten te bevatten. De resultaten wijzen er op, dat -uitgaande van het basaal membraanexpressiepatroon- de groepen met cystadenomen en cystadenocarcinomen homogeen zijn, terwijl in de groep ovariumtumoren met "borderline" maligniteit twee subgroepen zijn te onderscheiden, waarbij het basaal membraanexpressiepatroon van de ene subgroep overeenkomt met dat van cystadenomen, en van de tweede subgroep lokaal overeenkomt met het irregulaire patroon in cystadenocarcinomen.

In hoofdstuk 4 worden de resultaten vermeld van een studie naar basaal membraanpatronen bij een groep van kleine tumoren van de nier, waarvan het biologische gedrag moeilijk voorpelbaar is. Gebruik makend van antistoffen, gericht tegen laminine en type IV collageen werden 41 tumoren van de nier, gediagnostiseerd als "niercel carcinoom" of "adenoom van de nierschors" en in diameter varierend van enkele millimeters tot $6 \mathrm{~cm}$, op het basaal membraan expressiepatroon onderzocht. De vraagstelling richtte zich met name op een mogelijke relatie tussen basaal membraanpatronen en morfologische parameters als kernpolymorfie (uitgedrukt in "nuclear grade") en diameter van de tumor, die beide van prognostische waarde zijn.

De bevindingen wezen uit, dat in deze groep tumoren voorkomen met intacte basaal membranen en tumoren, waarbij de basaal membraan onregelmatig gevormde defecten bevat. Een intacte basaal membraan werd significant meer aangetroffen in kleine niertumoren, met een diameter minder dan $10 \mathrm{~mm}$, terwij] de meeste van de grotere tumoren defecten lieten zien. Beoordeling van de "nuclear grade" in relatie tot deze diametercategorieën leverde op, dat laaggradige tumoren significant meer voorkwamen in de groep tumoren met een diameter minder dan $10 \mathrm{~mm}$.

Aangezien uit de literatuur bekend is, dat laaggradige tumoren significant minder metastaseren dan hooggradige tumoren en gezien de intacte basaal membranen in deze categorie, concluderen wij, dat voor het biologisch gedrag van een niertumor de diameter van meer of minder dan $10 \mathrm{~mm}$ van meer belang is, dan de diameter van $3 \mathrm{~cm}$, zoals totnogtoe regel werd aangenomen. Deze conclusie zou nog in een grotere meerjarenstudie moeten worden getoetst, waarin ook klinische follow-up gegevens konden worden betrokken.

Hoofdstuk 5 bevat de resultaten van een studie naar de expressiepatronen van type IV collageen en type VII collageen in het slijmvlies van mond- en keelholte en in het plaveiselcelcarcinoom van deze regio. Bij dit onderzoek werd gebruik gemaakt van een dubbelfluorescentiemethode. Ook werd gezocht naar een mogelijke relatie tussen expressie van deze beide basaal membraaneiwitten en tumordifferentiatie. De resultaten van het onderzoek wijzen uit, dat de depositiepatronen van type IV collageen en type VII collageen identiek zijn in de basaal membraan van het slijmvlies epitheel en de afvoerbuisjes van de speekselkliertjes, maar verschillend bij het klierepitheel, bloedvaatjes, spiervezels, zenuwvezels en vetcellen, waar type IV collageen wel aanwezig was in de basaalmembraan in tegenstelling tot type VII collageen. Wanneer de expressiepatronen van beide antigenen werden vergeleken, dan bleek, dat er een toenemende co-expressie was, naarmate het carcinoom beter gedifferentieerd was. Bovendien bleek er intracytoplasmatische expressie van type VII collageen in alle slecht gedifferentieerde en sommige van de matig gedifferentieerde carcinomen, waarbij het vermogen om type VII collageen extracellulair af te zetten kennelijk niet aanwezig was. De resultaten suggereren, dat type VII collageenexpressie een gevoelige indicator is voor invasieve groei bij maligne tumoren. 
In hoofdstuk 6 wordt het expressiepatroon van type IV collageen en type VII collageen beschreven in het normale slijmvlies van de dikke darm, in adenomen en adenocarcinomen, ontstaan uit dit slijmulies

Er bleek een discrepantie in het vò̀rkomen van deze componenten, waarbij type IV collageen in regelmatige patronen gezien werd in de basaal membraan van het epitheel, van bloedvaatjes, spier- en zenuwvezels en type VII collageen geheel ontbrak. Bij adenomen werden, bij gebruik van type IV collageen, regelmatige basaal membraan patronen waargenomen. Type VII collageen expressie werd uitsluitend aangetroffen in de basaal membraan grenzend aan dysplastisch epitheel en het oppervlakkige, histologische normaal gebouwde epitheel in de onmiddellijke omgeving van het adenoom. Met behulp van antilichamen, gericht tegen hoog-en laagmoleculaire keratines werd geen aanwijzing gevonden voor gewijzigde differentiatie van cellen grenzend aan de basaal membraan met type VII collageen expressie.

Bij adenocarcinomen van de dikke darm werd onregelmatige expressie gezien van type IV collageen, wijzend op uitgebreide defecten. Ook hier was het expressiepatroon niet identiek met type VII collageen, omdat deze component alieen in goed en matig gedifferentieerde tumoren werd aangetroffen.

$\mathrm{De}$ in dit hoofdstuk vermelde bevindingen wijzen op een voorbijgaande expressie van type VII collageen, welke alleen waargenomen wordt bij epitheel met dysplastische veranderingen en carcinomen van matige of hoge differentiatiegraad. Ook hier zou type VII collageen een waardevolle indicator kunnen zijn bij vaststelling van vroeg invasieve groei bij adenocarcinomen van de dikke darm.

In hoofdstuk 7 worden de resultaten beschreven van een studie naar de expressiepatronen van type IV collageen en type VII collageen in het endometrium bij de fysiologische, hormonaal bepaalde fasen, bij hyperplasie van het endometrium en bij het adenocarcinoom.

Omdat onderlinge vergelijking van deze expressiepatronen tot het onderwerp van de studie behoorde, werd ook immunofluorescentie dubbelkleuring aangewend.

Bij het normale endometrium werden met type IV collageen normaal gevormde basaal membranen gezien. Type VII collageen werd uitsluitend waargenomen in de meer oppervlakkige niveau's van het endometrium en dan aan het eind van de proliferatiefase en in de secretiefase. Bij hyperplasie zonder epitheelatypie bleek er een vrijwel identiek expressiepatroon van type IV en type VII collageen; in gevallen van endometriumhyperplasie mèt epitheelatypie bleek de basaal membraan ononderbroken en regelmatige immunoreactiviteit voor type IV collageen te bezitten, terwijl immunoreactiviteit voor type VII collageen op sommige plaatsen afwezig bleek.

$\mathrm{Bij}$ het adenocarcinoom werden onregelmatige type IV collageen expressiepatronen gezien, terwijl type VII collageen immunoreactiviteit geheel ontbrak.

De resultaten van deze studie tonen aan, dat type VII collageen tijdens het verloop van de menstruele cyclus in het oppervlakkige niveau tot expressie komt. Dit fenomeen, en de verschillende type IV en type VII collageen expressie berust mogelijk op de specifieke, en van type IV collageen afwijkende functie. Aangezien type VII collageen geassocieerd wordt met de verankeringsfibrillen tussen basaal membraan en aangrenzend stroma, zou expressie van dit eiwit kunnen wijzen op de noodzaak van steviger hechting van epitheel aan het stroma, bijvoorbeeld bij inwerking van uitwendige wrijvingskrachten op het oppervlakkige epitheel van het endometriumslijmvlies. De discrepante expressie van beide basaal membraan componenten bij endometriumhyperplasie zou mogelijk van belang kunnen zijn bij histologische diagnostiek in het grensgebied tussen atypie en invasieve groei.

Hoofdstuk 8, tenslotte, geeft een overzicht van de resultaten van de studies tegen de achtergrond van interacties tussen tumorcellen, basaal membraan en extracellulaire matrix bij invasief groeiende tumoren en in het bizonder tumoren met beginnende invasieve groei en tumoren met "borderine" maligniteit. 
Er wordt op gewezen, dat de resultaten van de studies aanwijzingen geven voor het biologische gedrag van deze tumoren en van belang kunnen zijn voor de diagnostische histopathologie. Om deze aanwijzingen om te zetten in concreet toepasbare, wetenschappelijk gefundeerde criteria, is uitbreiding met klinisch-pathologische follow-up studies geïndiceerd en noodzakelijk. 


\section{DANKWOORD}

Het is nu circa 4 jaar geleden, dat, tijdens een wandeltocht langs de Jeker en op weg naar de bron van deze rivier, de kiel werd gelegd voor dit proefschrift. Na met Jan Willem Arends en Henny Peltenburg, vanaf Maastricht een dag lang de rivier stroomopwaarts gevolgd te hebben en in Tongeren (België) in een Italiaans restaurant te hebben gegeten ("wenst $U$ de spaghetti met of zonder frites, heren?"), kwam tijdens het natafelen in café "Relax", nabij het station van Tongeren, het onderwerp "promoveren" ter sprake. Hierbij suggereerden mijn wandelgenoten om de reeds verrichtte inspanningen op het gebied van basaal membraan immunohistochemie uit te breiden tot een promotiewaardig onderzoek.

Het resultaat ligt voor $U$. Het is tot stand gekomen, mede dankzij de directe of indirecte betrokkenheid van velen en voor een belangrijk deel bewerkt binnen de vakgroep Pathologie van de Rijksuniversiteit Limburg te Maastricht. Hier waren het Margriet Pijls, Birgitte Kuypers-Engelen en Annick Moors, die op voortreffelijke wijze voor de immunohistochemische bewerkingen zorgdroegen. Het materiaal werd grotendeels verzameld uit het archief van de vakgroep Pathologie van het Academisch Ziekenhuis Maastricht, maar ook werd materiaal verkregen van de afdeling Pathologie van het "de Wever" ziekenhuis te Heerlen (hoofd: dr Joh Koudstaal) en door de medewerking van dr Johan van der Beek (vakgroep Keel-, neus- en oorheelkunde), prof dr RW Stockbrügger (vakgroep Interne geneeskunde, gastro-enterologie), de medewerksters van de polikliniek gastro-enterologie, dr Delemarre (destijds hoofd van de afd Pathologie van het Nederlands Kanker Instituut te Amsterdam) en dr Fibo ten Kate (toentertijd verbonden aan de afd Pathologie van de Erasmus Universiteit te Rotterdam). Bij de statistische berekeningen ben ik geholpen door Geert Jan Tangelder (vakgroep Fysiologie) en Erik Thunnissen (vakgroep Pathologie).

Bij de fotografische opnamen werd geadviseerd door de Audiovisuele Dienst van het Academisch Ziekenhuis Maastricht en de foto's werden door Eline Huiben afgedrukt op de afdeling Fotografie van het Gerechtelijk Laboratorium ( $\mathrm{Hr}$ van den Heuvel).

$\mathrm{Bij}$ de tekstverwerking heb ik nuttige en bruikbare tips en adviezen gekregen van de heren van der Wulp en Oeij (afd Informatie \& Automatisering van het G.L.) en voor het uitprinten heb ik meermalen van hun faciliteiten gebruik mogen maken. Bij de afwerking van de opmaak van het manuscript ben ik op uitstekende wijze bijgestaan door Ruud Leliveld van Datawyse (Maastricht), die op welhaast virtuoze wijze met de computer weet om te gaan.

Ik wilde dit dankwoord niet beëindigen zonder prof dr Roelof Willighagen genoemd te hebben, die, als coördinator van het keuze-onderwijs Pathologie in Leiden, mijn belangstelling voor dit specialisme wist te op te wekken, hetgeen resulteerde in een opleiding te Maastricht bij prof dr GJV Swaen.

Gedurende deze voor mij belangrijke en bijzondere Maastrichtse periode heb in diverse functies met velen samengewerkt. Ook ben ik, gesuperviseerd door prof dr Fré Bosman, in de gelegenheid geweest wetenschappelijk onderzoek te verrichten. Dit proefschrift is dan ook in nauwe samenwerking met hem en prof dr Jan Willem Arends tot stand gekomen, met hulp c.q. adviezen van (binnenkort dr) Adriaan de Bruïne (vakgroep Pathologie) en dr Miek Havenith (Streeklaboratorium voor Pathologie te Enschede). 
De kritische commentaren en suggesties van de beoordelingscommissie, bestaande uit prof dr FCS Ramaekers, prof dr RW Stockbrügger, prof dr G Kootstra, prof dr J Drukker en prof dr DJ Ruiter hebben tot verbetering van vorm en inhoud geleid.

Op enkele, voor mij belangrijke momenten kon ik in alle rust en daardoor op efficiënte wijze, delen van dit proefschrift schrijven in de inspirerende atmosfeer en omgeving van het Groot Seminarie te Brugge (prof dr Adelbert Denaux).

Een belangrijk deel van het proefschrift werd geschreven tijdens mijn huidige aanstelling bij het Laboratorium voor Gerechtelijke Pathologie te Rijswijk. Ik hoop, dat ik de ervaring, die bij het schrijven van dit proefschrift is opgedaan, kan aanwenden bij het verder ontwikkelen van de forensische pathologie in Rijswijk.

Tenslotte wilde ik Sonja, Rinske, Maarten en Iris noemen, die door hun creatieve aanpassing in de nieuwe omgeving en inzet bij verhuizing en verbouwing op indirecte wijze een bijzondere aandeel hebben gehad bij de totstandkoming van dit proefschrift. 


\section{CURRICULUM VITAE}

1947 geboren te 's-Gravenhage

1961-1966 Maerlant Lyceum (H.B.S.-b) te 's-Gravenhage

1966-1974 studie Geneeskunde aan de Rijksuniversiteit te Leiden, keuze-onderwijs Pathologie (dr R.G.J. Willighagen) en een half jaar doctoraal-assistentschap pathologie

1975

wetenschappelijk ambtenaar bij het ministerie van Onderwijs en Wetenschappen ter standplaats Maastricht (Rijksuniversiteit Limburg i.o.)

1975-1980 opleiding tot patholoog-anatoom (prof. dr. G.J.V. Swaen), Annadal Ziekenhuis te Maastricht

1980-1991 patholoog(-anatoom), universitair docent rijksuniversiteit Limburg

1991- patholoog bij het Laboratorium voor Gerechtelijke Pathologie (ministerie van Justitie) te Rijswijk 
Datawyse I Universitaire Pers Maastricht ISBN 9052780749 